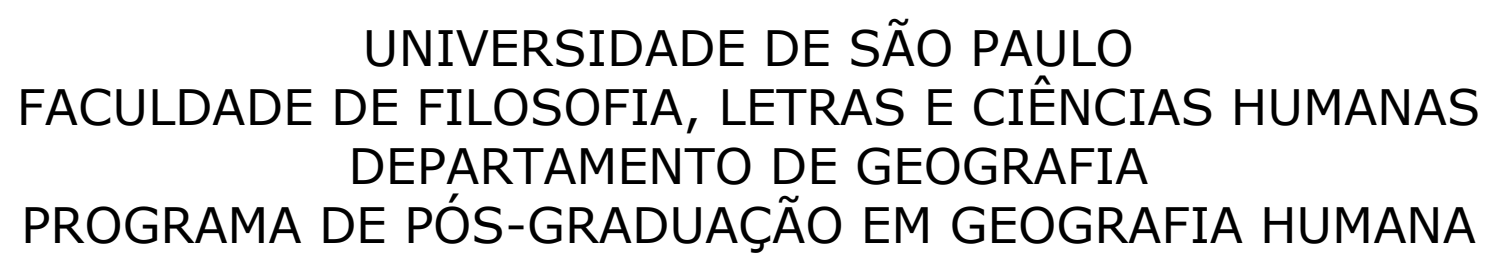

MARIA CRISTINA DE JESUS NOVAES

\title{
A segregação socioespacial em Guarulhos e a representação em mapas
}

(versão corrigida) 


\author{
UNIVERSIDADE DE SÃO PAULO \\ FACULDADE DE FILOSOFIA, LETRAS E CIÊNCIAS HUMANAS \\ DEPARTAMENTO DE GEOGRAFIA \\ PROGRAMA DE PÓS-GRADUAÇÃO EM GEOGRAFIA HUMANA
}

\title{
A segregação socioespacial em Guarulhos e a representação em mapas
}

\author{
versão corrigida \\ (o exemplar original se encontra disponível no CAPH da FFLCH)
}

MARIA CRISTINA DE JESUS NOVAES

Dissertação apresentada ao Programa de Pós-Graduação em Geografia Humana do Departamento de Geografia da Faculdade de Filosofia, Letras e Ciências Humanas da Universidade de São Paulo, para a obtenção do título de Mestre em Geografia.

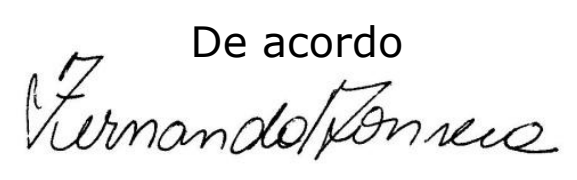

Orientadora: Profa. Dra. Fernanda Padovesi Fonseca 
BRASI DE CIMA E BRASI DE BAXO

Meu compadre Zé Fulô, Meu amigo e companhêro, Faz quage um ano que eu tou Neste Rio de Janêro; Eu saí do Cariri Maginando que isto aqui Era uma terra de sorte, Mas fique sabendo tu Que a miséria aqui do Su É esta mesma do Norte.

Tudo o que procuro acho. Eu pude vê neste crima, Que tem o Brasi de Baxo E tem o Brasi de Cima. Brasi de Baxo, coitado!

É um pobre abandonado; O de Cima tem cartaz, Um do ôtro é bem deferente: Brasi de Cima é pra frente, Brasi de Baxo é pra trás.

Aqui no Brasi de Cima, Não há dô nem indigença, Reina o mais soave crima De riqueza e de opulença;

Só se fala de progresso, Riqueza e novo processo De grandeza e produção. Porém, no Brasi de Baxo Sofre a feme e sofre o macho A mais dura privação.

(PATATIVA DO ASSARÉ. Cante lá que eu canto cá. 11. ed. Petrópolis: Vozes, 1978. p. 271-272.) 


\section{AGRADECIMENTOS}

Agradeço, inicialmente, à minha orientadora, Prof. Dra. Fernanda Padovesi Fonseca, em especial por ter me oportunizado conciliar o estudo da cartografia e a teoria do professor Milton Santos.

Agradeço à Prof. Dra. Maria Elena Simielli e ao Prof. Dr. Ricardo Mendes Antas Jr. pelas sugestões no exame de qualificação, que contribuíram para a estruturação desta dissertação.

Aos geógrafos Eduardo Dutenkefer e Vânia Gonçalves, pelas trocas cartográficas.

À Secretaria Municipal de Segurança Pública de Guarulhos, pela disponibilização de dados sobre os homicídios dolosos.

Ao amigo e geólogo Marcio Roberto Magalhães, pelo fornecimento de alguns mapas de Guarulhos.

Aos amigos da EMEF "João Domingues Sampaio" e da EE "Lydia Kitz Moreira".

À minha mãe, Joana Maria Novaes, minhas irmãs Lucimara de Jesus Novaes e Cristiane de Jesus Novaes e ao meu pai Wilson Rodrigues Novaes.

Aos meus filhos José Pedro Novaes de Barros, Luís Diogo Novaes de Barros e Tainá Cristina Novaes de Barros e ao meu companheiro Edson José de Barros. 


\section{SUMÁRIO}

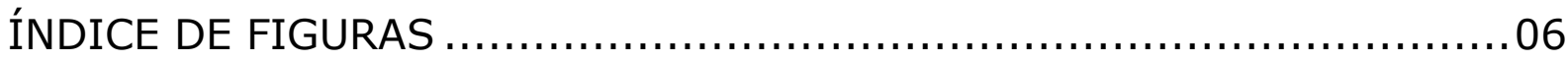

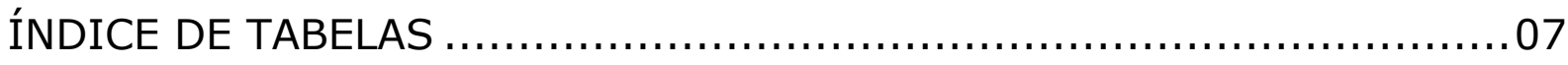

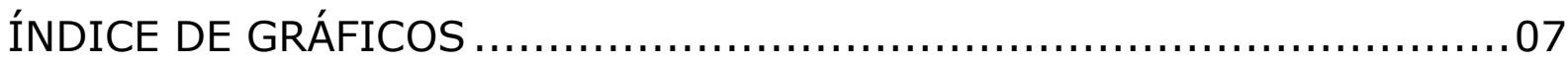

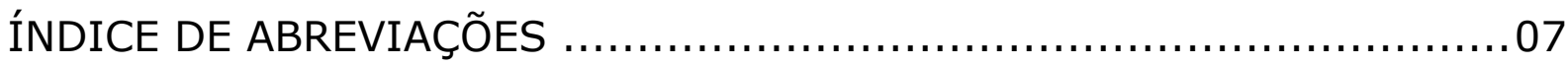

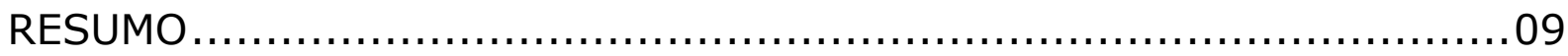

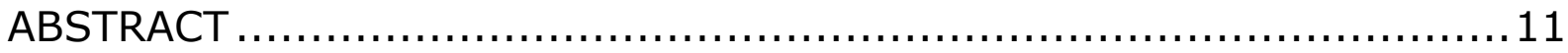

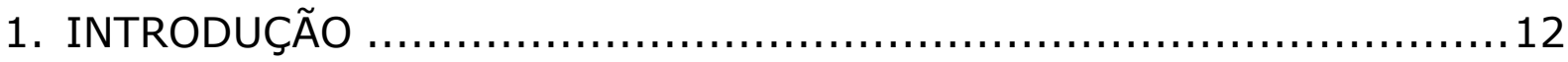

1.1 Por que a escolha do Município de Guarulhos para desenvolver a

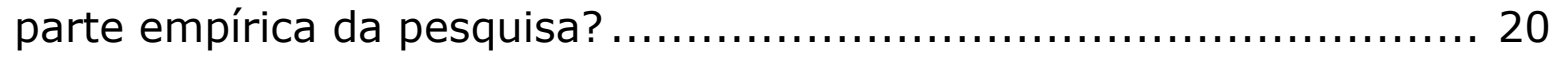

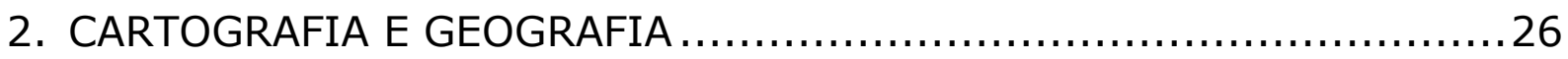

2.1 Os mapas e a representação da segregação socioespacial de

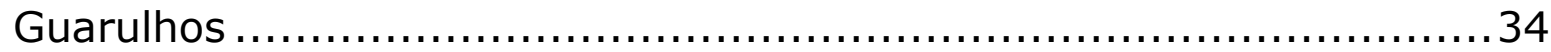

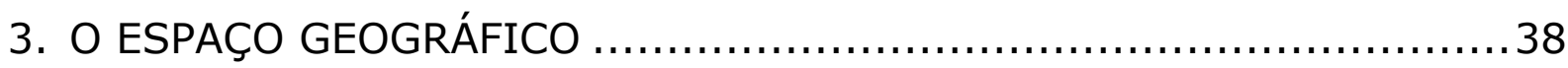

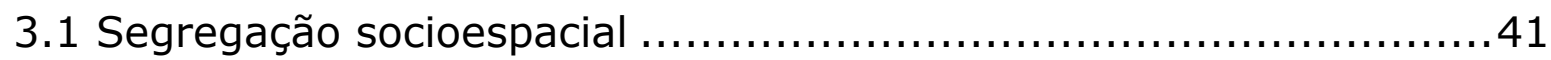

3.2 Formação territorial de Guarulhos ...................................5 52

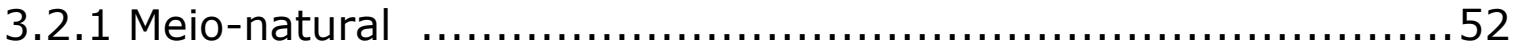

3.2.2 Meio técnico pré-maquinas ..................................... 52

3.2.3 Meio técnico baseado no uso das máquinas para a produção e a circulação ferroviária ......................................................... 53

3.2.4 O meio técnico e organizacional da produção industrial e da

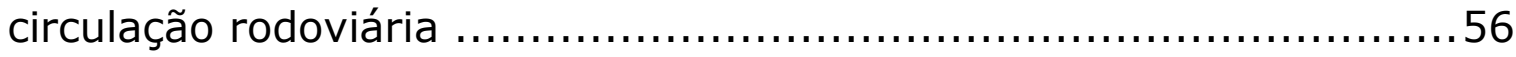

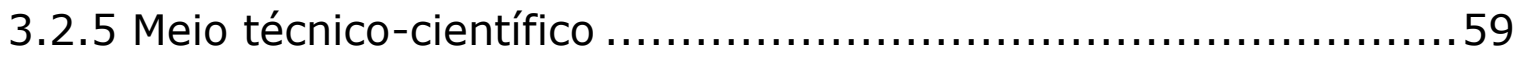

3.2.6 Meio técnico-científico-informacional ..............................66

3.3 Segregação socioespacial em Guarulhos................................ 94

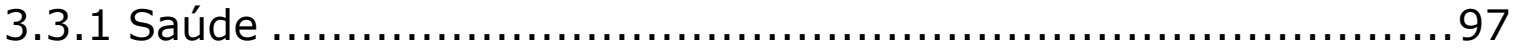

3.3.2 Educação ........................................................... 110

3.3.3 Moradia, lazer e cultura ......................................... 123

3.3.4 Meio técnico-científico-informacional e a segregação socioespacial .............................................................. 139

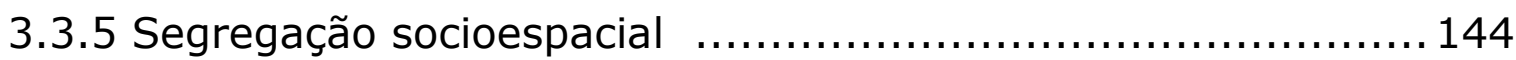

3.3.6 A segregação socioespacial e a distribuição dos homicídios . ...146

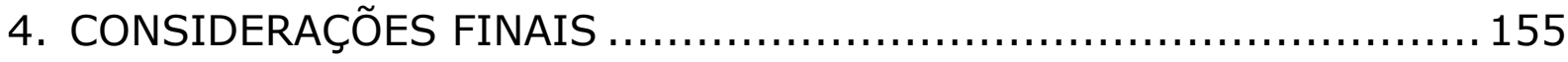

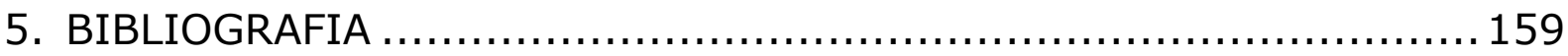




\section{ÍNDICE DE FIGURAS}

Figura 01 - Guarulhos na RMSP e no Estado de São Paulo ................20

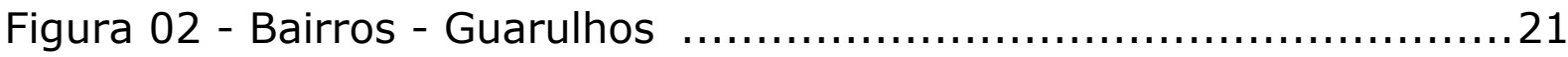

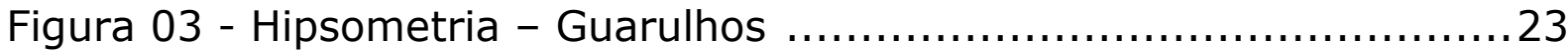

Figura 04 - Cobertura arbórea - Guarulhos …............................25

Figura 05 - Os mapas segundo suas funções (Lévy, 2003) ...................35

Figura 06 - Expansão urbana de Guarulhos .................................59

Figura 07 - Expansão da mancha urbana do município de São Paulo. Em

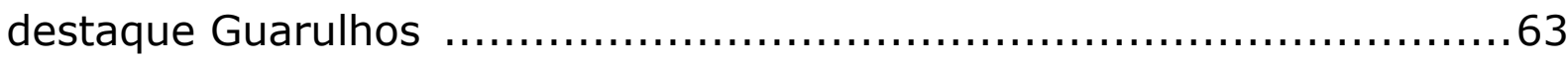

Figura 08 - População por Bairros - Guarulhos (1980) ................... 70

Figura 09 - População absoluta por bairros - Guarulhos (1980, 1991, 2000

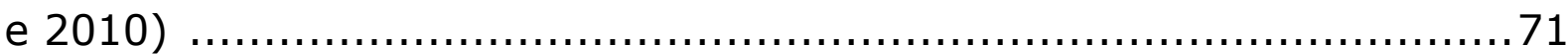

Figura 10 - Incremento populacional - Guarulhos (1980-1991)...........73

Figura 11 - Incremento populacional - Guarulhos (1991-2000) ...........75

Figura 12 - Incremento populacional - Guarulhos (2000-2010) ............77

Figura 13 - Usos dominantes do território Guarulhos .......................86

Figura 14 - Faixas etárias (crianças, adolescentes e idosos) - Guarulhos

Figura 15 - Equipamentos de Saúde - Guarulhos ......................... 105

Figura 16 - Total de pessoas abrangidas pelas UBS- Guarulhos .......... 109

Figura 17 - Distribuição das escolas das redes estadual, municipal,

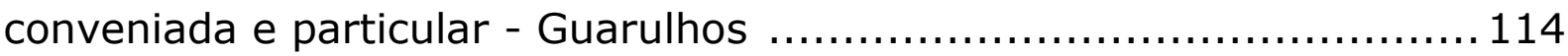

Figura 18 - Distribuição das creches municipais e da rede conveniada e proporção de crianças com menos de 3 anos - Guarulhos .................118

Figura 19 - Número de alunos por pré-escolas municipais e proporção de crianças de 4 e 5 anos - Guarulhos ......................................... 119

Figura 20 - Número de alunos por escolas do ciclo I e proporção de crianças de 6 a 10 anos - Guarulhos ....................................... 120

Figura 21 - Número de alunos por escolas estaduais do ciclo II e ensino médio e proporção de crianças e adolescentes - Guarulhos ................122 Figura 22 - Número médio de moradores por domicílio- Guarulhos .....124 Figura 23 - Favelas segundo a localização territorial - Guarulhos .........126 Figura 24 - População absoluta total e população absoluta e relativa em aglomerados subnormais por bairros - Guarulhos

Figura 25 - Alvarás emitidos pela PMG entre 2007 e 2012, para edificações acima de 3 pavimentos - Guarulhos 
Figura 26 - Parques municipais - Guarulhos

Figura 27 - Principais equipamentos públicos vinculados a culturaGuarulhos

Figura 28 - Rendimento médio mensal por domicílio - 2010

Figura 29 - Proporção da população dos bairros em função da cor da pele

Figura 30 - Sistema de circulação principal existente e projetado para RMSP

Figura 31 - Figura 31 - Área segregada que concentra relativamente as melhores condições territoriais - Guarulhos. 145

Figura 32 - Taxa de homicídios por agressão (2000) e dolosos (2005) por 100.000 pessoas - Guarulhos.

\section{ÍNDICE DE TABELAS}

Tabela 01 - Crescimento Populacional de Guarulhos - 1940 a 2010 ......69 Tabela 02 - As dez maiores empresas, segundo o faturamento de 2007 .88 Tabela $03-\mathrm{N}^{0}$ de agências por instituição bancária .......................91 Tabela 04 - Domicílios particulares permanentes - classes de rendimento

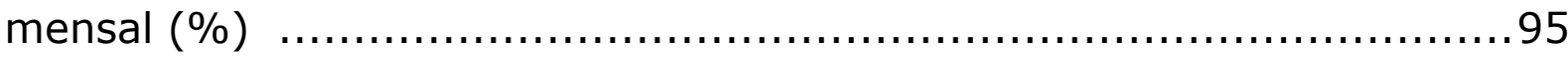

Tabela 05 - Valores financeiros destinados a saúde por esfera de governo (reais) .98

Tabela 06 - Total de Despesas Municipais - Saúde (Em reais) .99

Tabela 07 - Despesas da Secretaria Municipal de Saúde - 2006 a 2010 (reais) 100

Tabela 08 - Estatísticas vitais de Guarulhos, RMSP e ESP 101

Tabela 09 - Estrutura etária da população 101

Tabela 10 - Hospitais Guarulhos 106

Tabela 11 - Matrículas iniciais por nível e rede de ensino - 2000 e 2010

Tabela 12 - Moradores e Domicílios particulares permanentes, com ordenamento regular, por condição de ocupação, 2010

Tabela 13 - Favelas de Guarulhos 125

\section{ÍNDICE DE GRÁFICOS}

Gráfico 01 - PIB - 1980 a 2009 - Guarulhos 80 
Gráfico 02 - Pessoas formalmente contratadas Guarulhos - 1991 a 2010

Gráfico 03 - Proporção de Estabelecimentos do Total

Gráfico 04 - Participação do setor nos vínculos empregatícios 84

Gráfico 05 - Rendimento médio dos vínculos empregatícios Guarulhos -

2010 85

Gráfico 06 - Número de agências bancárias 90

Gráfico 07 - Leitos SUS 106

Gráfico 08 - Homicídios dolosos em Guarulhos, RMSP e ESP

Gráfico 09 - Mortes por agressão em Guarulhos (SEADE) 148

\section{ÍNDICE DE ABREVIAÇõES}

BIRD - Banco Internacional para a Reconstrução e Desenvolvimento

CPMF - Contribuição Provisória Sobre Movimentação Financeira

ESP - Estado de São Paulo

FMI - Fundo Monetário Internacional

FUNDEB - Fundo de Manutenção e Desenvolvimento da Educação Básica e Valorização dos Profissionais da Educação

FUNDEF - Fundo de Manutenção e Desenvolvimento do Ensino Fundamental e Valorização dos Profissionais da Educação

GPS - Global Positioning System

IBGE - Instituto Brasileiro de Geografia e Estatística

LDB - Lei de Diretrizes e Bases da Educação

PIB - Produto Interno Bruto

PMG - Prefeitura Municipal de Guarulhos

PROUNI - Programa Universidade para todos

PROER - Programa de Estímulo à Reestruturação e ao Fortalecimento do Sistema Financeiro Nacional

PSF - Programa Saúde da Família

RMSP - Região Metropolitana de São Paulo

SAMU - Serviço de Atendimento Móvel de Urgência

SEADE - Fundação Sistema Estadual de Análise de Dados - SP

SIG - Sistema de Informação Geográfica

SIM - Sistema de Informação de Mortalidade

SUS - Sistema Único de Saúde

UBS - Unidade Básica de Saúde

USP - Universidade de São Paulo

UTI - Unidade de Terapia Intensiva 


\section{RESUMO}

Considerando o espaço geográfico como uma das instâncias da sociedade, tal como Milton Santos, discutiu-se neste trabalho a relação entre a segregação socioespacial e a distribuição dos homicídios. A cartografia foi parte importante do instrumental dessa análise. O município de Guarulhos, que integra a Região Metropolitana de São Paulo (RMSP), foi o objeto empírico. Ele foi compreendido como uma realidade mediada pela formação socioespacial brasileira e pelos estágios da técnica, que estão fundamentados na teoria e no método propostos por Milton Santos. No caso, foram identificados os meios geográficos: natural, técnico e técnicocientífico-informacional, operando na formação do município. A segregação socioespacial foi interpretada como consequência da acessibilidade desigual aos objetos e serviços sociais, principalmente aos serviços públicos, algo que é ampliado pelo uso seletivo do território por parte dos atores hegemônicos, advindos da construção do meio técnico-científico-informacional. A partir da identificação dos meios geográficos e da percepção da segregação socioespacial identificaram-se as áreas no interior do município, nas quais, relativamente, encontram-se as melhores condições territoriais. Com relação aos mapas, a proposta foi conciliar diferentes possibilidades de representação das informações, de acordo com a leitura espacial que se deseja enfatizar em cada um deles, reafirmando as potencialidades e as limitações dos diferentes tipos de mapas. Nesse sentido, foram construídos mapas com fundo euclidiano para representar os dados absolutos e aqueles que localizavam os objetos pelo território. Por outro lado, foram feitas anamorfoses para os dados que enfatizavam a distribuição da população no interior do município, bem como as informações relativas a ela. Procurou-se ressaltar o potencial da linguagem visual na simplificação das informações, como meio para a sua democratização, o que pode contribuir como instrumento de esclarecimento da população, sobretudo, pelo conteúdo dos mapas. 
Palavras chaves: meios geográficos, desenvolvimento técnico, objetos, desigualdade, cartografia. 


\section{ABSTRACT}

Considering geographical space as one of the instances of society, like Milton Santos, it was discussed in this work the relationship between sociospatial segregation and the distribution of homicides. Cartography was an important part of this analysis instrumental. The city of Guarulhos, which integrates São Paulo Metropolitan Region (RMSP), was the empirical object. It was understood as a reality mediated by Brazilian sociospatial formation and by the technical stages, grounded on theory and method proposed by Milton Santos. In this case, geographical media were identified: natural, technical and technical-scientific-informational, operating in the city formation. Sociospatial segregation was interpreted as a consequence of unequal access to social objects and services, mainly to public services, something which is amplified by selective use of the territory by the hegemonic actors, arising from the construction of technical-scientific-informational environment. Based on the identification of geographical media and on the perception of sociospatial segregation, areas in the city were identified in which, relatively, the best territorial conditions were found. Relating to maps, the proposal was to conciliate different possibilities of information representation, according to the spatial reading which was to be emphasized in each one, restating the potentialities and limitations of different types of maps. In this sense, Euclidean background maps were constructed to represent absolute data and those which located the objects by territory. On the other hand, anamorphosis was made for the data which emphasized the population distribution in the city, as well as information related to it. It was sought to emphasize the potential of visual language on simplifying information, as a means to its democratization, which can contribute as instrument of clarification for the population, especially, through the maps contents.

Key words: geographical media, technical development, objects, inequality, cartography. 


\title{
INTRODUÇÃO
}

\author{
"Do rio que tudo arrasta, diz-se que é violento. Mas \\ ninguém chama violentas às margens que o comprimem."
}

Bertolt Brecht

A despeito da complexidade que envolve a temática violência, como mostram diversas pesquisas acadêmicas, a abordagem dada à questão, por parte expressiva dos meios de comunicação, governantes e de certos estudiosos, é reducionista, por diferentes interesses ou pela limitação do enfoque metodológico adotado, entre outros.

Uma das limitações, é abordar a violência apenas como uma questão de polícia. Diversos exemplos podem ser atrelados a tal ideário e, dentre eles, foi escolhido o que diz respeito aos acontecimentos correntes na Universidade de São Paulo (USP), por considerá-los significativos para a argumentação que se desenvolve.

A atual gestão da USP trouxe, para o interior do campus da Capital, a Polícia Militar para fazer a segurança, junto com a guarda universitária terceirizada e usou como justificativa o aumento das ocorrências criminais. Ao analisar a atuação militar, observa-se que o uso da força policial tem sido direcionado, também, para reprimir os estudantes e demais funcionários, assim como os seus métodos de luta, que forjam para combater as diversas formas de sucateamento da universidade pública. Tais métodos podem envolver ocupações de prédios públicos, ação que ganha grande destaque como violenta, visão fortemente incentivada pelos meios de comunicação de massa.

Entende-se que antecede o juízo de valor, o questionamento sobre o porquê de tais tipos de ação necessitarem ser deliberadas. Ao analisar os conflitos ora tratados nessa universidade como caso de polícia, considera-se que são questões de cunho político, e que a gestão democrática chegaria a outros encaminhamentos para esse subespaço, inclusive para a questão do aumento das ocorrências criminais. Um dos resultados desse 
centralismo da gestão da universidade é a confusão dos espíritos conceito desenvolvido por Milton Santos (2000), que torna a questão controversa e cria uma disputa entre os defensores e opositores da presença da polícia militar no campus. Outro questionamento necessário é saber, por que a USP, maior universidade da América Latina, detentora de acervo acadêmico avançado sobre democracia e violência, não o coloca em prática e presta um grande serviço a população em geral?

Em busca de uma visão mais abrangente, Marilena Chaui (1999), professora de Filosofia da USP, mostra que a violência real no Brasil é ocultada por vários dispositivos. Um deles é o jurídico, que localiza a violência apenas no crime contra a propriedade e contra a vida. Outro é sociológico, que concebe a violência um momento de anomia social, isto é, como um momento no qual grupos sociais "atrasados" ou "arcaicos" ao entrarem em contato com grupos sociais "modernos" e "desadaptados", tornam-se violentos.

Há o dispositivo de exclusão, que distingue os "brasileiros não violentos" e os "violentos", estes sendo todos os que, "atrasados" e deserdados, empregam a força contra a propriedade e a vida de "nós brasileiros não violentos". Aponta, ainda, um dispositivo de distinção entre o essencial e o acidental, segundo o qual, por essência, a sociedade brasileira não seria violenta e, portanto, a violência é apenas um acidente na superfície social, sem tocar em seu fundo essencialmente não violento, o que explica os meios de comunicação se referirem à violência com as palavras "surto", "onda", "epidemia", "crise", isto é, termos que indicam algo passageiro e acidental, não focando a questão estrutural.

Para a autora, ao abordar a violência como um fato esporádico superável, escamoteiam-se as diversas formas de violência que estruturam a sociedade brasileira, entre elas as intolerâncias religiosas, sexuais, culturais; as exclusões e desigualdades econômicas, políticas e sociais; o autoritarismo que regula todas as relações sociais e a corrupção presente em várias instituições (CHAUI, op.cit.). 
Compartilhando tais premissas, Arlete Moyses Rodrigues (2004) aponta a necessidade de compreender, como violência, a falta de urbanidade com que convivem aqueles instalados, muitas vezes pelo próprio Estado, em áreas sem infraestrutura urbana e equipamentos de consumo coletivo. Raramente, analisa-se a violência a que são submetidos ao serem instigados diariamente a comprar e/ou usufruir do conforto que a cidade/ o urbano parece oferecer. Simultaneamente, nega-se a eles o acesso aos benefícios do progresso que eles próprios ajudam a construir.

Milton Santos (2000) afirma que, o que mais se dissemina, principalmente, são as violências funcionais derivadas, sendo que atenção bem menor é dada ao que denomina violência estrutural, que está na base da produção das outras, e constitui a violência central original. Para ele, a violência estrutural é resultante da presença e das manifestações conjuntas em estado puro do dinheiro, da competitividade e da potência, que conduzem à emergência de novos totalitarismos e permite pensar que se vive numa época de globalitarismo, muito mais que de globalização ${ }^{1}$.

Essa associação entre violência estrutural e violência funcional é bastante evidente na atual crise econômica que atinge os países membros da comunidade europeia. A Grécia, por exemplo, um dos países submetido a medidas de austeridades impostas pela Comissão Europeia, o Banco Central Europeu e o Fundo Monetário Internacional, resultaram em drásticos cortes econômicos e privatizações, em troca do socorro econômico. O resultado de tais ações tem levado os gregos a protestos e manifestações, duramente reprimidos pela polícia, inclusive resultando em algumas mortes. Dados mostram que os índices dos suicídios na Grécia aumentaram em $18 \%$ desde 2010 , em Atenas o aumento foi de $25 \%$ (Por "fim" digno ..., 05 abril 2012).

\footnotetext{
${ }^{1}$ [...] "em busca do dinheiro, em seu estado puro, indispensável à existência das pessoas, das empresas e das nações, as formas pelas quais ele é obtido, sejam quais forem, já se encontram antecipadamente justificada. Assim como tudo vale para obtenção do dinheiro em estado puro, tudo vale em termos de competividade, "sua prática provoca um afrouxamento dos valores morais e um convite ao exercício da violência" [...]. Para exercer a competividade em estado puro e obter o dinheiro em estado puro, o poder (a potência) deve ser exercido em estado puro".
} 
Assim como os suicídios, os homicídios estão entre as violências funcionais, que podem ser numerosas naqueles lugares em que a ausência de condições dignas de existência é expressiva, o que muitas vezes dá, àqueles que sofrem com a exclusão, a alcunha de violentos. Para Alba Zaluar (1994), a associação entre pobreza e criminalidade são explicações deterministas e reducionistas, uma vez que a pura lógica da necessidade econômica, que subjaz à tal vinculação, não consegue dar conta dos intricados processos pelos quais as taxas de criminalidade aumentam.

Tais discussões se relacionam à vivência que se teve durante a infância e adolescência no extremo leste do Município de São Paulo, no Itaim Paulista ${ }^{2}$, um dos bairros que apresentam elevado número de homicídios. No local, enfrentou-se a precariedade da moradia, das escolas, da saúde, do transporte público, do lazer e o medo de várias formas do que é noticiado como violência: doméstica, roubos, furtos, chacinas, extermínios, rixas, homicídios. Estes perfizeram a infância, atingindo as pessoas da vizinhança que, em poucos anos, passaram a ser com os amigos adolescentes e adultos. Naquele cotidiano, não se entendiam as motivações envolvidas nos homicídios, vistos como parte "natural" da vida. Por outro lado, também se compartilhava a luta empreendida pelas pessoas para a "superação" das precariedades.

Para a maioria, morar num bairro periférico de baixa renda, além de tornar-se um segregado, as oportunidades são desiguais em nível social, econômico, educacional, renda, cultural. Isso significa que um morador de um bairro periférico pobre tem condições mínimas de melhorar social ou economicamente, implica normalmente apenas reproduzir a força de trabalho disponível para o capital (NEGRI, 2008).

A vivência no Itaim Paulista associa-se à afirmação de Milton Santos (1994a), de que a cidade, onde tantas necessidades emergentes não

2 Em 28/07/2010, na Folha de São Paulo, no mapa que representa os homicídios no Município de São Paulo, o Itaim Paulista faz parte dos bairros que registram as maiores ocorrências. 
podem ter resposta, está fadada a ser tanto teatro de conflitos crescentes como lugar geográfico e político da possibilidade de soluções.

Para Sergio Adorno (2002), atualmente, se por um lado é refutada a tese que relaciona a pobreza, a delinquência e a violência, por outro olhar, diversos estudos reconhecem relações entre a persistência, na sociedade brasileira, da concentração da riqueza e das precárias condições de vida nos chamados bairros periféricos das grandes cidades e a explosão da violência fatal. Assim vários autores mostram a maior quantidade de homicídios nas áreas periféricas das capitais e regiões metropolitanas, principalmente, onde, dentre outros fatores, apresentam urbanização acelerada, alta concentração de moradores, deficiência na infraestrutura urbana, ocupação do solo irregular, em que é flagrante a ausência de instituições públicas encarregadas de promover o bem-estar social. Entre os que assim veem os problemas estão Nanci Cardia (2000), Nanci Cardia e Sueli Schiffer (2002), Sergio Adorno (2002), Pedro Javier A. Hughes (2004), Ana Maria Leite de Barros et al. (2004), Ignez Costa B. Ferreira e Nelba Azevedo (2005), Alam Gualberto Teixeira (2004) e Patrícia Rivero (2010).

A partir das ponderações sobre a questão da violência e da distribuição desigual dos homicídios no interior das grandes cidades, optou-se pelo estudo do que ora é tratado como desigualdades, ora como exclusão ou segregação e foi estabelecido como objetivo central da dissertação de mestrado discutir a relação entre a segregação socioespacial e a distribuição dos homicídios que, apesar, de ser a forma letal, é uma das violências derivadas, segundo Milton Santos (2000).

Além do entendimento sobre o que é violência, outro fator que pode contribuir para que o enfoque seja reducionista é a forma de análise adotada, que pode resultar de estudos que procedem apenas com base na espacialização em mapas e/ou sistemas de informações geográficas, entre outros, de diferentes dados, como os socioeconômicos. Esse tipo de estudo Maria Laura Silveira (2006a) se enquadra numa epistemologia da 
extensão, que ignora o espaço geográfico do ponto de vista existencial de todos que o constitui.

No dizer de Jacques Lévy (2003) é a negação do papel fundamental do espaço na vida dos homens, que resulta do fato que há distância entre os objetos da sociedade. Diante dessa distância e dos problemas e da problemática que ela levanta, os operadores sociais constroem, em função do contexto societário, estratégias, atos, ideologias, tecnologias, saberes. A Geografia se preocupa em pensar essas estratégias, esses atos e saberes, essas ideologias, tecnologias e seus contextos de construção e de atualização e não apenas em constatar a existência das distâncias. Estas não são redutíveis a intervalos ou espaçamentos. As geografias do espaçamento agem sempre numa simples aproximação de medida de posições, numa topografia ou topologia dos objetos da sociedade, interessantes, mas insuficiente.

Em busca da superação de tal tipo de enfoque propõe-se o estudo do espaço geográfico a partir da definição de Milton Santos (1994b, 1997) "um conjunto indissociável de sistemas de objetos e de sistemas de ações". Como afirma, é apenas a relação que existe entre as coisas que permite realmente conhecê-las e defini-las, posto que the dão concretude. Os fatos isolados são abstrações (SANTOS, 2008).

Desta forma

[...] qualquer proposta de análise e interpretação que pretenda inspirar ou guiar uma intervenção endereçada ao conjunto da sociedade não pode prescindir, então, de uma visão desse todo. Incapazes de gerar mudanças que englobem a totalidade do território e da sociedade, as intervenções parciais atendem a interesses particulares ou apresentam resultados efêmeros e inoperantes. (SANTOS et al, 2000, p.3).

Tal entendimento é possível, conforme Santos (2004), se o espaço é considerado uma instância da sociedade, tal como a econômica e a cultural-ideológica, o que quer dizer que como instância ele contém e é contido pelas demais. $O$ espaço não pode ser apenas formado pelas 
coisas, os objetos geográficos, naturais e artificiais, cujo conjunto nos dá a Natureza, ele é tudo isso, mais a sociedade: cada fração da natureza abriga uma fração da sociedade atual.

Concepção de espaço geográfico desenvolvida também por Jacques Lévy (2003), que o define como uma dimensão que atravessa a sociedade de parte a parte, e sua associação não é hierárquica, nenhuma predomina sobre a outra. Assim, o espaço é societário de parte a parte, como a sociedade é espacial de uma ponta a outra, mas não exclusivamente (porque ela é ao mesmo tempo temporal, social, política...). O espaço se constitui, portanto, de um subsistema do Todo, que reside também na parte.

Completando, Santos (2005) escreve que a escolha de um tema de pesquisa se minimiza, pois a explicação de qualquer fato espacial depende das outras estruturas constitutivas do espaço. Assim, não se diferencia a escolha entre uma porção do espaço ou uma questão específica referente a todo território. O objeto de estudo passa a ser uma categoria analítica da Totalidade.

Diante de tais concepções, o espaço geográfico apresenta-se como uma possibilidade de estudo, uma vez que ele interage com a violência estrutural ou a que dela deriva.

Outro objetivo estabelecido para a presente dissertação foi o emprego e discussão dos mapas como parte do instrumental de análise, que são entendidos, segundo propõe John Brian Harley (1991, p. 7), como uma "representação gráfica que facilita a compreensão espacial de objetos, conceitos, condições, processos e fatos do mundo humano".

Os mapas possibilitam outra forma de leitura das informações diferente das linguagens textual-sequencial. Eles fornecem uma apreensão visual, que permite que as informações sejam apreendidas de forma mais imediata, simultânea, intuitiva e sintetizadora.

Ressalta-se, contudo, como abordam Jacques Lévy (2003 e 2008), Fernanda P. Fonseca (2004), Gisele Girardi (2000 e 2007), entre outros, que as potencialidades dos mapas para a análise espacial não se aplicam 
a qualquer tipo de mapa, e estão condicionadas a vários fatores, como a concepção de espaço geográfico e do próprio mapa adotadas. Tais dificuldades, por exemplo, estão presentes na cartografia voltada para representação dos espaços internos das cidades, alvo da presente pesquisa, e que a cartografia tem buscado desenvolver. Assim, a presente dissertação constituiu uma oportunidade de aprofundar tal discussão.

Como os mapas foram desenvolvidos com o estudo do espaço geográfico e a segregação socioespacial, além do capítulo introdutório, o segundo refere-se à Cartografia e Geografia, com um subitem sobre Os mapas e a representação da segregação socioespacial de Guarulhos. O terceiro capítulo é sobre o Espaço Geográfico subdividido na Segregação socioespacial, na Formação territorial de Guarulhos, na Segregação socioespacial em Guarulhos, que inclui entre os subitens a Segregação socioespacial e a distribuição dos homicídios. O quarto capítulo versa sobre Considerações Finais, seguido da Bibliografia.

No próximo item apresenta-se a área de estudo. 


\subsection{Por que a escolha do município de Guarulhos para desenvolver a parte empírica da pesquisa?}

O município de Guarulhos está localizado na região concentrada ${ }^{3}$, onde a presença de ciência e tecnologia pelo território se apresenta em maior densidade, tendo como polos principais as metrópoles de São Paulo e do Rio de Janeiro (SANTOS e SILVEIRA, 2001).

A Figura 1 mostra a Região Metropolitana de São Paulo (RMSP), da qual Guarulhos faz parte, junto com outros 38 municípios, incluindo a Capital do Estado de São Paulo.

Guarulhos tem diferentes tipos de vínculos com o município de São Paulo e limites a oeste, sul e sudoeste; a noroeste com Mairiporã, a leste com Arujá, a sudeste com Itaquaquecetuba, a nordeste com Santa Izabel e a norte com Nazaré Paulista, que não está inserido na RMSP (Figura 01).

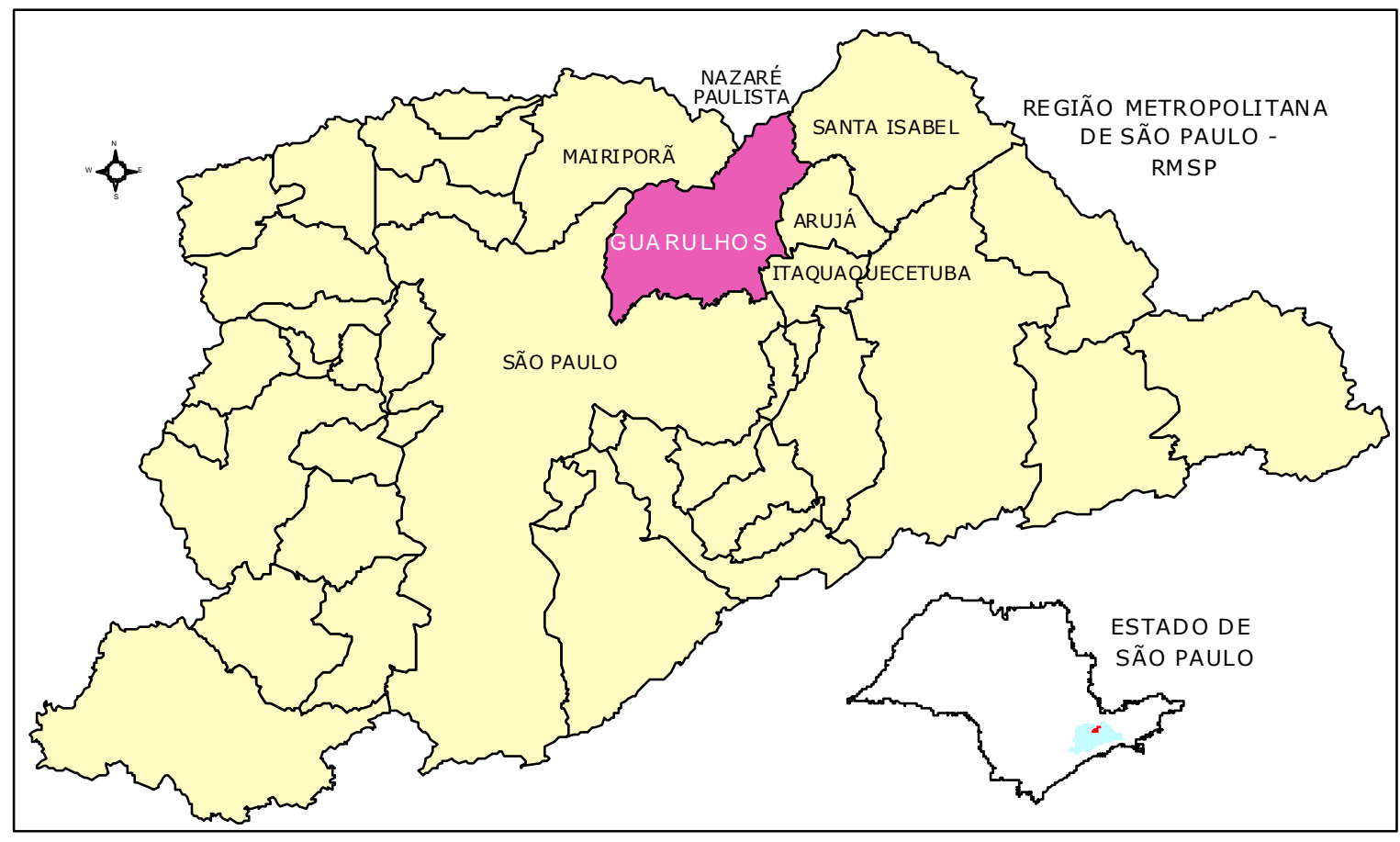

Figura 01 - Guarulhos na RMSP e no Estado de São Paulo.

\footnotetext{
${ }^{3} \mathrm{O}$ conceito de região concentrada é desenvolvido por Milton Santos e Ana Clara Torres Ribeiro. Abrange os Estados do Sudeste (Espírito Santo, Rio de Janeiro, Minas Gerais e São Paulo), os Estados do Sul (Paraná, Santa Catarina e Rio Grande do Sul) e dois Estados do Centro-oeste (Mato Grosso do Sul e Goiás) (SANTOS e SILVEIRA, 2001).
} 
Ocupa, legalmente, a área de 319,19 km², subdividida em 47 bairros, representados na Figura 02. Abriga 1.221.979 habitantes, correspondentes a 6,6\% da população da RMSP, e é a segunda maior do Estado de São Paulo. É o $13^{\circ}$ município mais populoso do Brasil e o primeiro entre os que não são capitais (IBGE, 2010).

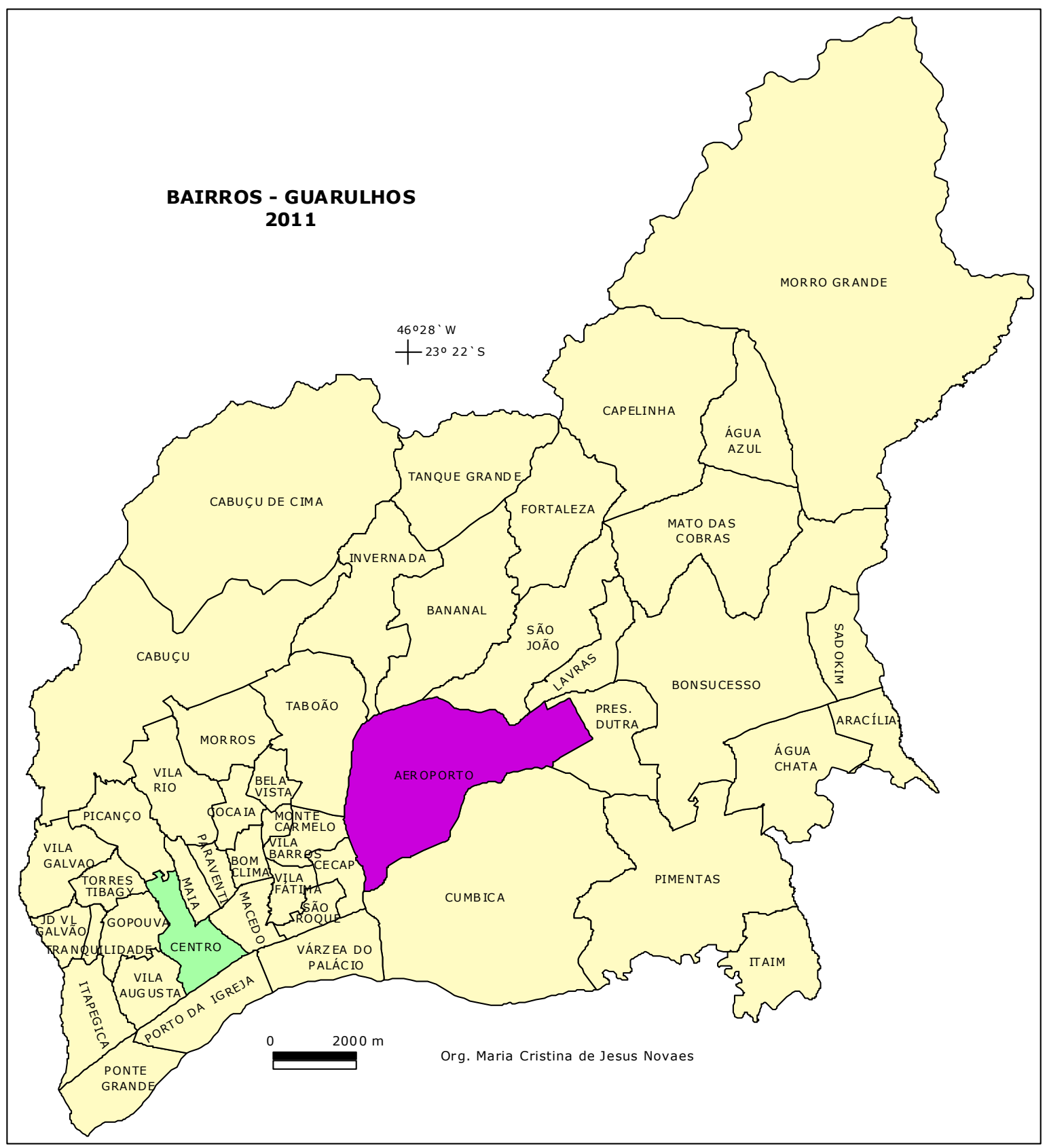

Figura 02 - Bairros - Guarulhos. 
Conforme os dados do IBGE (2009), Guarulhos detém o nono maior PIB brasileiro, e o segundo maior entre os municípios paulistas. Destaca-se a indústria de transformação, o setor de serviços e importante sistema de circulação formado pelo maior aeroporto internacional da América Latina, pelas Rodovias Dutra, Ayrton Senna e Fernão Dias, que atravessam seu território.

Assim como para a formação socioespacial brasileira, a relativa pujança econômica não se traduz em qualidade de vida para a maior parte dos munícipes guarulhense, o que é constatado a partir de diferentes indicadores. Entre estes, o mapa da Pobreza ${ }^{4}$ e Desigualdade dos municípios brasileiros, realizado pelo IBGE em 2003, apontando que a pobreza incide sobre $43,21 \%$ da população. Outro indicador desenvolvido pela Fundação Seade, que focaliza o município como unidade de análise, a partir das dimensões de longevidade, educação e renda, que participam com pesos iguais na sua determinação, aponta que o município apresenta níveis de riqueza elevados, mas não exibe bons indicadores sociais.

As precariedades citadas são perceptíveis na paisagem guarulhense, assim como é destacado, em boa parte dos estudos bibliográficos realizados. Outro exemplo são os dados dos homicídios ocorridos em 2000, que são elevados, e distribuídos de forma desigual entre os bairros. A conjunção desses fatores foi determinante para a escolha de Guarulhos, para este estudo.

Ainda é importante uma breve apresentação do meio físico do município, uma vez que ele contribui para o entendimento da formação territorial e da segregação socioespacial. Esse meio físico pode ser compartimentado em três unidades principais e, para contribuir para a sua visualização, foi elaborado o mapa hipsométrico, conforme a Figura 03.

\footnotetext{
4 "A pobreza absoluta é medida a partir de critérios definidos por especialistas que analisam a capacidade de consumo das pessoas, sendo considerada pobre aquela pessoa que não consegue ter acesso a uma cesta alimentar e de bens mínimos necessários à sua sobrevivência".

http://www.ibge.gov.br/home/presidencia/noticias/noticia visualiza.php?id noticia=1293 \&id página $=1$.
} 
As Serras (Pirucaia, Bananal e Itaberaba) e os Morros Altos, com altitudes entre 850 metros e 1422 metros, estruturados por terrenos cristalinos com rochas de idades Pré-Cambrianas, compõem uma dessas unidades, situando-se ao norte da falha do Rio Jaguari (de sentido sudoeste-nordeste).

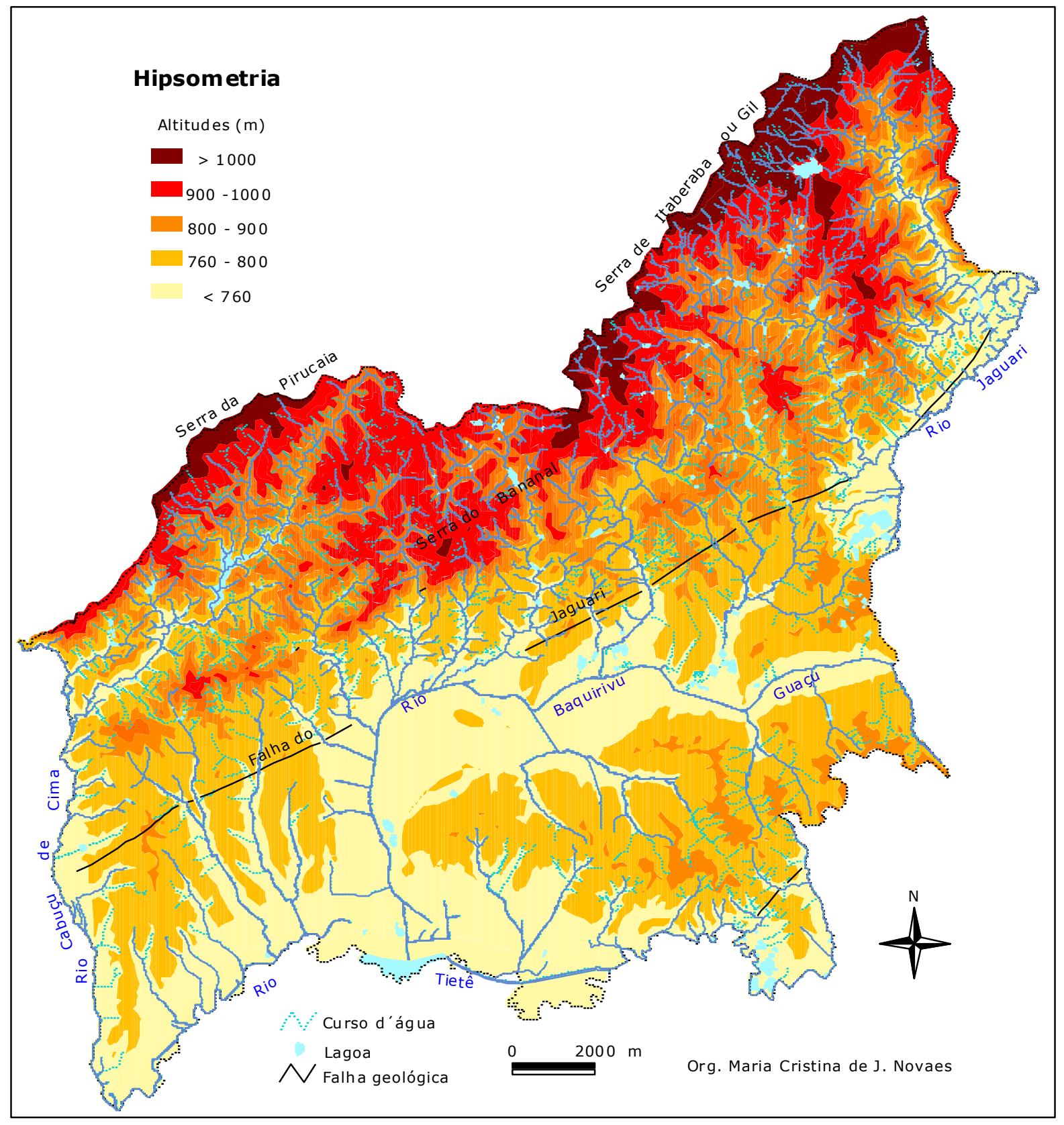

Figura 03 - Hipsometria - Guarulhos. 
Ao sul da falha do Rio Jaguari, onde se concentra a população, há as Colinas e Morrotes, cuja altimetria varia entre 760 e 850 metros, aproximadamente; são constituídos pelos terrenos sedimentares terciários da Bacia de São Paulo. As colinas ao leste são sustentadas pelos afloramentos de rochas metamórficas de sentido sudeste-nordeste.

A terceira unidade refere-se às Planícies Aluvionares Quaternárias, que acompanham os Rios Tietê (localizado no limite sul) e Rio Jaguari (situado a nordeste do município e afluente do Rio Paraíba do Sul), assim como os afluentes principais deles. Correspondem às áreas mais baixas do município, com altitudes inferiores a 760 metros.

Destaca-se que, praticamente, $1 / 3$ da área do município está recoberta por remanescentes de Mata Atlântica - primária e secundária. $\mathrm{Na}$ Figura 04, são ressaltadas as áreas verdes, que acompanham principalmente as serranias e morros altos, e algumas manchas entremeadas a área urbanizada.

Boa parte dos remanescentes está protegida em unidades de conservação. Ao sul a Área de Preservação Ambiental da Várzea do Rio Tietê e, ao norte, Parques Estaduais da Cantareira e da Serra do Itaberaba, Parque Municipal da Cultura Negra Sítio da Candinha, Estação Ecológica Tanque Grande e as Áreas de Preservação Ambiental Federal do Rio Paraíba do Sul e Municipal do Cabuçu-Tanque Grande. 


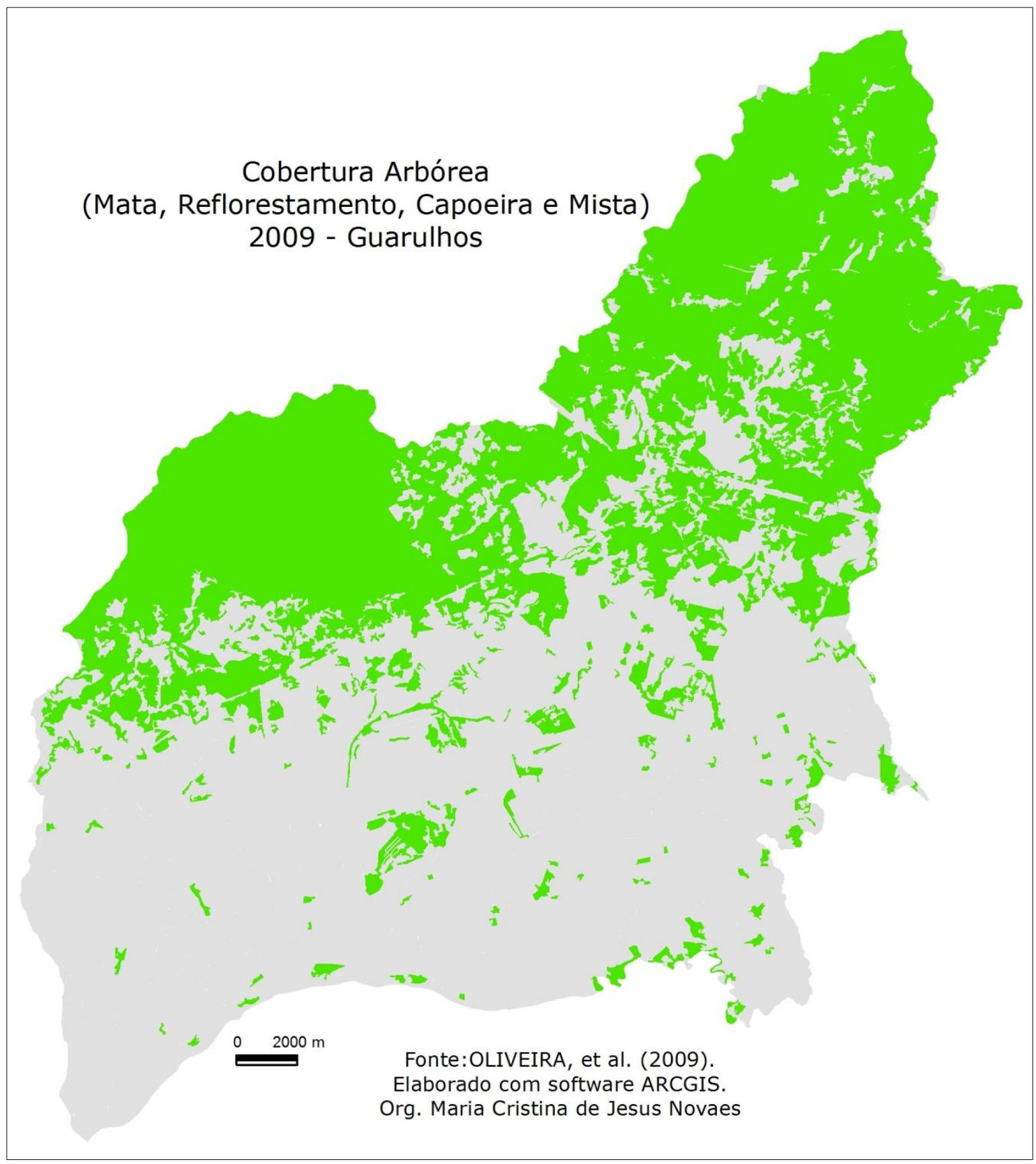

Figura 04 - Cobertura arbórea - Guarulhos. 


\section{CARTOGRAFIA E GEOGRAFIA}

"A missão do homem de ciência é arriscada por definição. Nenhum risco, porém, é tão grave quanto o de formular uma verdade científica como uma certeza eterna (SANTOS, 2004, p. 193)".

Ao realizar os estudos geográficos, normalmente recorre-se à cartografia como parte do instrumental de análise, o que culminou num dos objetivos da dissertação de mestrado. À tal prática, agregaram-se alguns questionamentos, entre eles: quais fatores podem favorecer ou dificultar o potencial dos mapas para leitura espacial? Como as cidades podem ser mais bem representadas nos mapas? Quais tipos de mapas favorecem a comunicação do espaço geográfico das cidades no atual momento histórico?

Diante da constatação de que não é qualquer tipo de mapa que garante a melhor expressão visual das informações representadas, foi feito um estudo bibliográfico do que pode interferir na relação entre geografia e cartografia.

A partir de leituras voltadas para a cartografia, principalmente as que se referem ao ensino no Brasil, um dos problemas elencados é o subemprego dos mapas, entre eles o seu uso para ilustração ou como mero artifício de localização. De acordo com Gisele Girardi (2000, 2007) grande parte dos geógrafos ainda usa mapas para tais finalidades.

Fernanda Padovesi Fonseca e Jaime Tadeu de Oliva (2002) pontuam que há uma indesejável autonomia da cartografia em relação à Geografia, em que há preocupação exclusiva com técnicas modernas na elaboração de produtos cartográficos e no seu uso apenas para a complementação de textos. Ressaltam o empobrecimento do papel da cartografia como linguagem urdidora de conhecimentos.

Em sua tese de doutorado, Fonseca (2004, p.7) amplia a discussão e mostra como a naturalização permeia as práticas cartográficas, que "revelam lacunas referentes às reflexões sobre representação e linguagem e o papel dessas na produção do conhecimento geográfico que se renova". 
Aponta que, em outros países, há mobilização teórica sobre a relação entre a Cartografia e a Geografia, em especial num contexto de renovação da Geografia. Mas, pondera que ainda não há força suficiente para expandir práticas geográficas mais abrangentes, e, no Brasil, a dificuldade é ainda maior.

Como escreve a autora, a renovação das bases epistemológicas da Geografia, implicou a reconstrução do conceito de espaço geográfico. Se antes a preocupação era a descrição dos lugares, hoje a Geografia é uma ciência social, que busca compreender a inscrição no espaço geográfico das relações sociais. Tal mudança deve ser considerada pela cartografia.

Nesse sentido, Jacques Lévy (2008, p. 153) aborda que o mapa é movimentado pela influência de seu referente - os espaços que ele busca representar -, dos conceitos que contribuem para pensar esses espaços, de suas técnicas específicas e dos usos do mapa pela sociedade. Para ele, é necessário retomar o diálogo entre a linguagem cartográfica e linguagem geográfica.

Para Jean Paul Board (1997) é necessária a incorporação de teoria e reflexão, ausentes no interior da disciplina cartográfica desde há muito, e não só com a "onda tecnológica". Isso também é mostrado por Fonseca (2004) a partir da dificuldade de a Cartografia lidar no interior da Geografia com um processo complexo de renovação teórica.

Essa ausência de reflexões teórica e epistemológica decorre de vários fatores, segundo Board (op.cit.), como a falta de formação, nessa direção, de pesquisas, de pesquisadores e de professores orientadores, além da supremacia das preocupações e ocupações com as técnicas cartográficas.

Tais constatações vão ao encontro das que foram feitas por Gisele Girardi (2007, p. 49) em que "[...] a produção do conhecimento, na aplicação técnica e na formação docente verifica-se mais a imposição das geotecnologias que movimentos de reflexão crítica [...]". Ressalta que não se trata de negação das técnicas, mas de entendê-las como possibilidades de releitura das técnicas cartográficas articuladas com a produção do 
conhecimento geográfico, e que o locus da articulação seria, precisamente, o ambiente de formação, os cursos superiores de Geografia. Enfatiza a importância da Cartografia Geográfica para a reflexão sobre a técnica e não somente como capacitação técnica.

Pondera que é preciso resgatar, ao profissional de Geografia, o nobre papel de usuário de mapas e que sua valorização deve estar na sua competência analítica e propositiva. E, no caso, as técnicas devem colaborar nesse sentido formativo. Conclui que "[...] o fazer cartográfico no âmbito da formação em Geografia deve primar pelo uso potencial das representações cartográficas no processo de descoberta" (GIRARDI, 2007, p.63). No caso, a autora busca destacar a função das representações cartográficas como fonte de cognição para a Geografia.

Para Fonseca (2004) um dos principais problemas resulta do fato de a Cartografia trabalhar com espaços absolutos, ao empregar o espaço euclidiano como única possibilidade, ignorando a renovação da Geografia, que resultou na definição do espaço relativo. Este possibilita a reflexão e a representação de outras métricas espaciais, inclusive métricas construídas socialmente, para superar a visão localizacionista, distributivista e descritivista da Cartografia convencional, baseada rigorosamente na concepção de espaço absoluto, ou espaço geométrico, algo que está automatizado ou naturalizado.

Patrick Poncet (2007), ao discutir a representação cartográfica do processo de mundialização destaca que grande parte do que é verdadeiro na geometria euclidiana na folha de um mapa convencional, é falso no espaço geográfico.

Reforça-se a ideia de espaço geográfico como palco, o que quer dizer que ele "não precisa ter uma característica propriamente geográfica, pois ele é apenas uma posição na superfície" (FONSECA, 2007, p. 94). É um "espaço plano" prévio, natural, único e indiscutível que faz parte da Geografia clássica e da Cartografia convencional, "todo o estudo de um lugar transforma a evidência (a localização euclidiana) em problema geográfico" (FONSECA, 2007, p. 95). Ressalta que não quer dizer que a 
ideia de extensão não tenha utilidade, mas que ela não é o centro das novas elaborações.

Os instrumentos metodológico-procedimentais necessitam ser desenvolvidos para a adoção de outras métricas, diferentes da métrica euclidiana, conforme Girardi (2007). Considera que é um campo fértil para ser explorado como componente da educação geocartográfica que acredita ser uma via de capacitação para mudanças na relação usuáriomapa.

Diante disso, apesar de permanecer na memória coletiva a associação Geografia-mapas, um caráter de mito fundador (GIRARDI, op.cit), ao avaliar internamente a relação da Cartografia e Geografia diversos problemas são elencados. Como mostra Lèvy (2008) o mapa é, hoje, ao mesmo tempo, supervalorizado e largamente ignorado.

Segundo Lévy, (2008) o mapa foi útil no auxílio de diversas atividades humanas, com forte componente espacial: a exploração, a guerra, o controle estatal e, mais recentemente, a escolha de implantação de empresas ou o turismo. Os mapas se multiplicaram e surgiram soluções novas e satisfatórias para os problemas técnicos de coleta de dados e de seu tratamento, graças à estatística, ao sensoriamento remoto e à informática. O sistema de informação geográfica (SIG) consagra o sucesso técnico de uma cartografia que se dissemina ainda que dissociada do suporte em papel. Por outro lado, observa certa crise do mapa a partir de quatro aspectos.

Um dos aspectos decorre das críticas que recaem sobre os mapas, que, como toda linguagem, pode servir como meio de persuasão para embasar ideologias fraudulentas, como aquelas de interesses geopolíticos e dos poderes hegemônicos. O assunto é discutido por John Brian Harley (2009) que mostra distorções intencionais do conteúdo dos mapas ao longo da História. Destaca que o cartógrafo não é um criador independente e está envolvido num conjunto de relações de poder, que cria suas próprias especificações. Essas distorções podem ocorrer a partir 
da manipulação das escalas, das projeções adotadas, do uso das cores, entre outros.

Lévy (2009) destaca outro aspecto da crise que se refere à dificuldade de universalização do mapa, por conta do esforço de aprendizado que ele requer, normalmente considerado desproporcional, diante das suas contribuições, e exemplifica, indicando que o aumento das mobilidades não resultou na expansão proporcional do uso do mapa.

O mapa parece cada vez mais substituível por outras técnicas, que configura um terceiro plano da crise. Entre as técnicas, o GPS (Global Positioning System, sistema de localização global) que difunde informações precisas sobre demanda e elimina a passagem por um documento, ao menos parcialmente, independente do uso que será feito.

Um quarto aspecto é que um grande número de fenômenos é mal representado nos mapas. É o caso das cidades que são espaços complexos e densamente povoados, e que, ao serem representadas em mapas com fundo euclidiano em escalas menores são reduzidas a figuras pontuais; e, no caso das escalas maiores, as áreas densamente povoadas ficam submersas pelas extensões vazias. Outro caso é que a complexidade e o entrelaçamento de espaços, subjetivos e objetivos, materiais e ideais, são "achatados" pela representação plana (LÉVY, 2003). Exemplos mostram que tais espaços deveriam ser representados, segundo outros parâmetros.

O caráter estático, de um documento fixo, face à possibilidade de organizar o mapa em sequências dinâmicas - feitas de imagens múltiplas - e a restrição a duas dimensões, perante os procedimentos de simulação de três dimensões sobre uma tela ou mesmo com os dispositivos mais sofisticados de "realidade virtual", são fatores que usam para apontar o fim do mapa. Lévy (2008), contudo, discute que esses novos objetos possuem possibilidades estimulantes, mas que não colocam necessariamente em questão o interesse por um documento estático em duas dimensões. Este permite um melhor controle do receptor, mantendo-o como leitor, mais do que como espectador. Ressalta que a 
multiplicação de tecnologias alternativas obriga, no entanto, o mapa a se "recentrar na sua trilha de excelência". O que quer dizer, considerar as interações entre espaço e extensão, a relação entre uma espacialidade particular e um fundo de mapa.

É precisamente o fundo de mapa que tem sido dominado pelo paradigma cartesiano (Fonseca, 2007) e sobre ele convém buscar outros princípios de construção. É necessária a abertura a outras métricas, entre elas distâncias relativas entre os objetos representados, não excluir as métricas reticulares, a investigação de fundos multiescalares, entre outros.

Para Roger Brunet (1988) o mapa é um instrumento que será mais e mais utilizado, para a pesquisa e como suporte de comunicação. Isso em função dos recursos da informática, que também imprimirão maior facilidade para a sua construção. Para tanto, é necessário conhecer as regras usuais de mapeamento fora do mundo dos cartógrafos.

Os múltiplos usos dos mapas merecem nossa atenção, não só a título de curiosidade, mas como uma fonte de conhecimento (LÉVY, 2003). O autor ressalta que a cartografia é uma linguagem particular, com um sistema de sinais codificados de forma arbitrária para possibilitar a comunicação das mensagens.

Como linguagem, os mapas são analógicos e simbólicos, não verbais e não sequenciais. Portanto, é um universo muito específico, em que uma das características é a dimensão analógica do mapa. A dimensão analógica, quer dizer que existe uma relação imediata, intuitiva entre o mapa e o terreno, ou seja, uma proporcionalidade entre os comprimentos da realidade e do mapa. Isso localiza o mapa entre o simbólico e o figurativo.

O componente analógico refere-se, inicialmente, à transferência dos elementos espaciais (posições, distâncias, configurações) da realidade a representar, mas o tratamento de outros componentes dessa realidade é simbólico. O princípio consiste em escolher para cada mapa uma série de formas simples, facilmente reparáveis e compatíveis entre elas. A opção 
em representar objetos de maneira figurativa (por exemplo símbolos pictóricos) é cada vez mais contestada na cartografia, por conta dos "ruídos visuais" que perturbam a leitura (LÉVY, op.cit.).

Com sua analogia e seu simbolismo, o mapa pode gerar duas espécies distintas de legitimidade: ser considerado a realidade, o que quer dizer na Geografia o espaço geográfico e, na verdade, o mapa é um espaço, não o espaço geográfico; e ser uma linguagem endereçada apenas aos especialistas, assim como as duas podem ser cumulativas. Isso resulta num desinteresse pela cartografia (LÉVY, 2003, 2008), que é uma das crises discutidas.

Outra característica fundamental do mapa é que, pela suas especificidades, ele favorece a leitura espacial. Em oposição às linguagens sequenciais, um mapa oferece, simultaneamente, ao leitor um conjunto de informações que contém e, assim, organiza uma coexistência de elementos que poderiam apresentar-se de maneira dispersa numa exposição oral. Apesar da presença de palavras, que deve ser considerada como um aspecto da semiologia gráfica, o mapa distingue-se claramente do discurso oral ou escrito. Opõe-se, geralmente, às linguagens cujos elementos são organizados por uma relação temporal exigente, uma ordem sucessiva rigorosa. Por outro lado, pelo seu caráter não sequencial, os mapas localizam-se entre as figuras, em oposição aos discursos, e entre elas pertencem à família das imagens. Esta assegura a vantagem de uma leitura global e instantânea, que permite fazer surgir estruturas espaciais simples, embora tenha o inconveniente da limitação da quantidade de informações que o leitor pode efetivamente apreender (LÉVY, 2003).

É importante ressaltar, conforme Fonseca (2004, 2007), que a força analógica dos mapas não é um dado absoluto, posto que muitos mapas sejam usados como simples listas ou como quadros de dados, organizados em função da localização dos objetos; assim, dispensam a função "ver", que constitui as virtudes da analogia. Explica que "[...] A analogia funciona quando a mensagem estiver expressa numa configuração 
espacial, como no espaço geográfico, sobre um conjunto sincrônico de relações entre os fenômenos localizados (2004, p. 217)". Isso é o que deve buscar a Cartografia, entendida como linguagem visual.

Lévy (2003) apresenta "um manifesto para o mapa", que desenvolveu com outros investigadores, e propõe algumas orientações para as interrogações e as expectativas do momento presente. Constata, inicialmente, a defasagem entre "as investigações promissoras" lançadas nos anos 1960 e as poucas repercussões concretas sobre a maneira de fazer mapas, ao continuar dando primazia ao fundo euclidiano. Também se preocupa com a falta de controle dos cidadãos sobre as bases de dados geográficos, incluindo aquelas que são detidas pelos organismos do Estado. Assim foram formuladas sete propostas:

1. Abandonar a ideia que o mapa construído num espaço euclidiano é um horizonte indispensável à representação geográfica;

2. Procurar, no espírito dos trabalhos já realizados, uma renovação conceitual;

3. Não renunciar a construir objetos cartográficos de acordo com códigos simples;

4. Questionar sobre os alcances e limites das linguagens cartográficas;

5. Considerar a educação do mapa como componente da inovação cartográfica;

6. Tratar também o mapa como vetor de diálogo político; e

7. Pensar o mapa como um bem comum a transformar.

Conclui, ainda, que estas pistas de reflexão fazem sentido para investigação, e também para todo o ambiente que liga as ciências e as técnicas de alta tecnologia "à sociedade da inteligência", ou seja, às condições necessárias para que crescentemente os indivíduos se apropriem dos conhecimentos e aumentem sua capacidade de dominar e transformar o seu ambiente (LÉVY, 2003). 
Ressalta que os desafios do mapeamento são sociais, quando se referem ao conhecimento teórico e à vida cotidiana, à linguagem e tecnologia, à economia e política, dificuldades parcialmente abordadas pelos cartógrafos e pelos usuários contemporâneos dos mapas, que dizem respeito à qualidade do diálogo entre pensamento geográfico e a linguagem cartográfica. Além disso, existe a necessidade de uma conexão efetiva entre a construção do conhecimento e a ação cidadã.

Com base na discussão apresentada e nas questões inicialmente levantadas, considerou-se que as preocupações apontadas no manifesto pelo mapa, contribuem para as questões inicialmente levantadas e foram norteadoras para a construção dos mapas para a presente dissertação.

\subsection{Os mapas e a representação da segregação socioespacial de Guarulhos}

Com base em Lévy (2003), Fonseca (2004) aponta quatro elementos como indispensáveis nos mapas: a escala, a projeção, a métrica (os três constituem o fundo do mapa) e o simbólico, que é formado pelas informações projetadas sobre o fundo de mapa. Todos os elementos são comunicantes. O problema é que é ignorada a função comunicante do fundo de mapa, considerado neutro e dominado pelo paradigma euclidiano (FONSECA, 2007, 2012).

Se todos os elementos fundamentais do mapa comunicam e cada cidade possui uma configuração espacial particular, no caso de Guarulhos, que tipo de mapa favorece a comunicação da sua formação territorial, e no caso da segregação socioespacial, que está embasada em diferentes desigualdades, como seria esse mapa?

Como não há apenas um tipo de mapa, mas vários que favorecem diferentes tipos de leitura espacial, as respostas às questões foram buscadas com base no que se pretendia comunicar. 
Para Lévy (2003), os mapas destinados à "leitura espacial" constituem um modelo gráfico, que possibilita a analise espacial dos fenômenos representados, que como explica Fonseca (2004, p.204), "[...] a rigor a "leitura espacial" não é um ler, é um ver, o que exige um tratamento visual do objeto representado, de modo a possibilitar um olhar instantâneo e global". Diferentemente desses mapas, há aqueles em a função "ver" é prejudicada pela forma de representação das informações, como é o caso daqueles mapas formados por tabelas de dados ou simples cruzamento de duas coordenadas terrestres que associam outras informações como toponímia, cotas hipsométricas ou batimétricas. Assim, os mapas são agrupados de acordo com a Figura 05, na qual se separa a construção dos mapas da dissertação de mestrado.

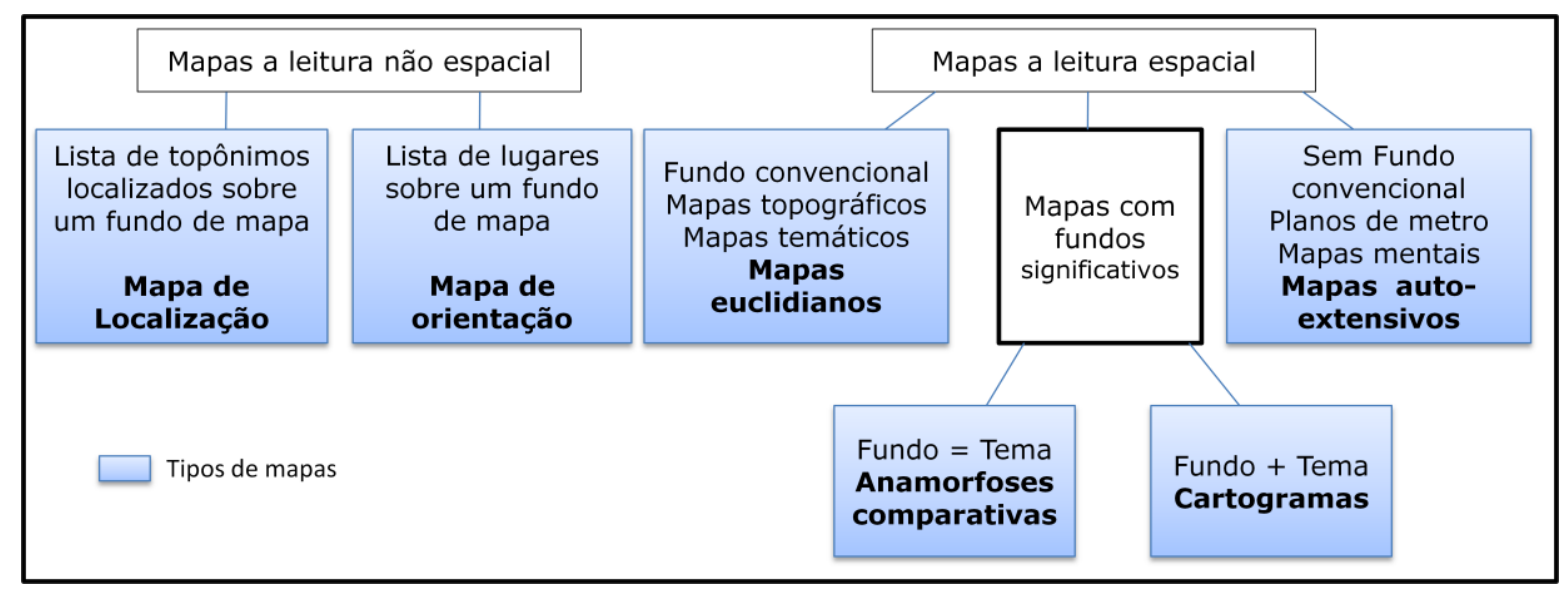

Figura 05 - Os mapas segundo suas funções (Lévy, 2003).

Pensando nos mapas voltados a "leitura espacial", questão relevante para a representação cartográfica da cidade de Guarulhos, é que sua área urbanizada se distribui por dois terços do seu território e no restante há significativas áreas de preservação, conforme mostrado na Figura 04. Ao construir os mapas exclusivamente num fundo euclidiano, ocorre o que Lévy, (2003) aponta como uma das crises do mapa, em que há o reforço dos "vazios" do território. Isso valoriza, na representação visual, as superfícies do terreno não habitadas, em detrimento daquelas densamente povoadas. Para o estudo da cidade é bastante significativo, 
sobretudo ao considerar que o objetivo central da dissertação é a segregação socioespacial, que está fundamentada em diferentes desigualdades.

Dentre as possibilidades de representações cartográficas desenvolvidas e que empregam outros parâmetros para o fundo de mapa, foram identificadas as anamorfoses.

Segundo Rosely Sampaio Archela e Hervé Théry (2008, p. 15)

[...] a anamorfose cartográfica ou geográfica é uma figura que expõe o contorno dos espaços representados de forma distorcida para realçar o tema. A área das unidades espaciais é alterada de forma proporcional ao respectivo valor, mantendo-se as relações topológicas entre unidades contíguas. Por exemplo, numa carta que represente a distribuição geográfica da densidade populacional, as áreas dos municípios podem ser ampliadas ou reduzidas de acordo com o afastamento daquele parâmetro em relação à média (ARCHELA e THÉRY, 2008, p.15).

Para Lévy (2004) como a anamorfose tem um fundo definido por uma grandeza diferente da superfície terrestre, explicita melhor as mensagens do que o "mapa tradicional" e pode contribuir numa leitura crítica, inclusive por parte dos não especialistas. Completando, Collete Cauvin (1995) destaca que as anamorfoses constituem uma transformação cartográfica espacial, que favorece a comunicação e o uso do mapa como instrumento de análise e de compreensão do espaço.

Tais potencialidades são consideradas importantes para a área de estudo e foram construídas as anamorfoses com o fundo formado pela população absoluta. A certas anamorfoses foram correlacionadas outras informações, entre elas aquelas formadas por dados relativos que não necessitavam de um grande número de classes e, em alguns casos, foi plotada a localização de equipamentos públicos.

Por outro lado, essa correlação de informações não se mostrou satisfatória para todos os mapas. Um caso foi o daqueles que precisavam de um número grande de classes para a representação dos dados numéricos. Outro caso era a necessidade de representar os dados em números absolutos e o inconveniente decorria da sobreposição de figuras 
geométricas às anamorfoses, que acabam encobrindo as áreas exíguas. Como destacado, as informações nos mapas têm como limite a quantidade que o leitor pode efetivamente apreender. Dessa forma, alguns mapas foram feitos no fundo euclidiano.

Há ainda outros dois tipos de mapas em que foi feita a opção pelo fundo euclidiano. Um deles foi para aqueles dados que a localização era a informação mais relevante, destacando-se os equipamentos públicos e de infraestrutura, que compõem a análise sobre a segregação. Ressalta-se, contudo, que o uso do mapa apenas para localização é superado pelas correlações e sínteses, que se constrói a posteriori. Outro diz respeito às informações constituídas por números absolutos, em que foram construídos mapas de símbolos proporcionais.

Assim discute-se o espaço geográfico. 


\section{O ESPAÇO GEOGRÁFICO}

"Energia nuclear O homem subiu à lua

É o que se ouve falar

Mas a fome continua..."

(Não Vadeia - Clementina de Jesus)

A Geografia é uma ciência do presente e tem como objeto de estudo, o espaço geográfico definido como "um conjunto indissociável, solidário e também contraditório, de sistemas de ações e sistemas de objetos", conforme Milton Santos (1997). Tais objetos, criados em diferentes momentos históricos, coexistem, entretanto, ainda, no momento atual.

Como ressalta Maria Adélia Aparecida de Souza (2005, p. 253), do ponto de vista miltoniano, "o espaço geográfico é uma totalidade dinâmica, produto das múltiplas totalizações a que está submetido o processo da história, a cada instante".

Nesse sentido, o espaço é formado pelo resultado material e imaterial acumulado das ações humanas através do tempo, e, também, animado pelas ações atuais que hoje the atribuem um dinamismo e funcionalidade (SANTOS, 1994b).

Diante disso, Santos (2004, p. 255-256) afirma que

[...] A reconstrução dos sucessivos sistemas temporais e dos sistemas espaciais sucessivos é um dado fundamental quando se busca uma explicação para as situações atuais. E isso implica uma identificação exata das periodizações em diferentes níveis ou escalas assim como o isolamento (com fins metodológicos) dos fatores dinâmicos próprios a cada período e a cada nível ou escala.

Para Santos (1997) é inseparável a ideia de meio geográfico e noção de sistema técnico. A técnica é o

[...] traço de união, historicamente e epistemologicamente. As técnicas, de um lado, nos dão a possibilidade de empiricização do tempo e, de outro lado, a possibilidade de uma qualificação precisa da materialidade sobre a qual as 
sociedades humanas trabalham. Então, essa empiricização pode ser a base de uma sistematização, solidária com as características de cada época. Ao longo da história, as técnicas se dão como sistemas, diferentemente caracterizados. (SANTOS, 1994b, p. 42).

Assim, propõe que a história do meio geográfico pode ser dividida em três etapas: o meio natural, o meio técnico e o meio técnico-científicoinformacional. Cada técnica pode, desse modo, ter sua história particular de um ponto de vista mundial, nacional ou local. São todas essas técnicas, incluindo as técnicas da vida, que nos dão a estrutura de um lugar (SANTOS, 1997).

Os lugares redefinem as técnicas. Cada objeto ou ação que se instala, insere-se num tecido preexistente, e seu valor real é encontrado no funcionamento concreto do conjunto. Sua presença também modifica os valores preexistentes. A idade das variáveis presentes em cada lugar acaba sendo medida como referência a fatores internos e externos, sobretudo nos países subdesenvolvidos, onde a história da produção é intimamente ligada à criação, nos países do centro, de novas formas de produzir (SANTOS, 1994b; SANTOS; SILVEIRA, 2001).

No meio natural, o homem escolhia em seu quinhão de natureza, o que Ihe podia ser útil para renovação de sua vida e construía seu espaço de vida com as técnicas que inventava para tirar do seu pedaço de natureza os elementos indispensáveis à sua própria sobrevivência; organizando a produção, organizava a vida social e o espaço, de acordo com suas próprias forças, necessidades e desejos (SANTOS,1994b).

O meio natural generalizado de que o homem se utilizava, praticamente sem transformações, vai sendo substituído pelo meio técnico. Neste, os objetos naturais passam a coexistir com os objetos artificiais, abrangendo um grande período, em que emergiu o espaço mecanizado.

É importante lembrar que o número e a qualidade dos artefatos variavam entre os diferentes recortes espaciais, em função da extensão e da densidade da substituição dos objetos naturais e dos objetos culturais, 
por objetos técnicos. Estes de prolongamentos dos corpos passam também a ser do território, verdadeiras próteses. Os tempos sociais tendem a se superpor e a contrapor-se aos tempos naturais (SANTOS, 1997).

Como ressaltam Santos e Silveira (2001), no começo era a natureza selvagem, formada por objetos naturais, os quais, ao longo da História, perdem sua vez para os objetos fabricados, objetos técnicos, mecanizados e, depois, para os cibernéticos, fazendo com que a natureza artificial tenda a funcionar como uma máquina.

A interdependência entre ciência e técnica, agora sob o comando da técnica, verifica-se em todos os aspectos e é uma situação que se encontra em todas as partes do mundo. Tais conteúdos de técnica, de ciência e de informação constituem a nova variável motora que permite reconhecer um novo sistema temporal, com a organização de um novo espaço (SANTOS, 1994b).

Assim, de acordo com autor, o meio técnico-científico informacional substituiu o meio-técnico há alguns decênios, empregados pelos cientistas, por ser um meio geográfico cujo território inclui, obrigatoriamente, ciência, tecnologia e informação. Paralelamente, inclui um novo sistema de natureza, e essa é a artificializada e não a natural.

Para Santos (1998) esses meio geográficos, além de sinônimos de espaço geográfico, o são também de território usado. Ressalta que é a utilização do território que faz dele objeto de análise social e não o território em si mesmo.

Com base nesses pressupostos Milton Santos e Maria Laura Silveira (2001) propõem uma periodização para os diferentes meios da formação socioespacial brasileira, que foi o referencial empregado para o estudo da formação territorial de Guarulhos, para discussão da segregação socioespacial. 


\subsection{Segregação socioespacial}

Um dos objetivos do presente trabalho é compreender a segregação socioespacial do Município de Guarulhos, e como os homicídios estão relacionados a ela. Dessa forma, foram discutidos alguns conceitos de segregação e suas relações com a área de estudo.

Constatou-se que o conceito de segregação é muito divulgado, mas não tanto definido. Foi o que ressaltaram Jacques Lévy e Michael Lussault (2003), ao escreverem que o termo é fartamente usado em várias ciências sociais, nas análises sobre as realidades urbanas, contudo, a precisão e o acordo sobre o que o conceito quer dizer, deixam a desejar.

Segundo os autores, é perceptível uma problemática social na repartição espacial das pessoas, dos grupos nas cidades, ou seja, nos espaços urbanos, e que está sempre associada à dinâmica social mais ampla, assim como qualquer outro fenômeno espacial, pois sendo um componente social, logo, torna-se um pleonasmo falar em "segregação socioespacial", como muitos geógrafos insistem em designar.

De acordo com eles, definir o que é segregação - uma visão mais ou menos pejorativa da repartição espacial, que se oporia a uma repartição democrática aberta às interações - é algo subordinado à visão de cidade, adotada pelos atores sociais, pela cultura, pela ciência e não existe segregação em termos absolutos.

A segregação é um recurso para se olhar a cidade, conforme Lévy e Lussault (op.cit), mas não tem força interpretativa global, como, por exemplo, teria a ideia de urbanidade, em que o discurso considera a segregação como um dos seus vários itens.

Destacam que a repartição espacial nas cidades é sempre algo complexo, logo não pode ser efeito de um único fator, como nada na cidade o seria. Assim, esses autores diagnosticam a segregação, quando, numa área particular em comparação com outras que estão na mesma organização urbana, aparecem três tendências concomitantes: 
1. uma tendência à estabilização numa área de situações de frágil diversidade societal (absoluta ou relativa);

2. a existência e a perenização de uma "descontinuidade externa" marcando nitidamente, para os indivíduos e os grupos, um limite entre o interior do espaço segregado e o exterior, limite que pode ser bem explicitado em termos materiais (muralhas, fechamento de áreas, descontinuidade na área construída, portais e afins);

3. uma propensão de parte (ao menos) dos atores sociais a procurar e/ou valorizar a distância criada estrategicamente para "afastar" outros atores e/ou outros objetos e/ou atividades da organização urbana (LÉVY; LUSSAULT, 2003).

Para eles, o fator econômico como a distribuição da renda, por exemplo, por si só, não gera necessariamente esse quadro complexo de segregação. São diversos fatores atuando ao mesmo tempo e, entre eles, sempre a intencionalidade dos atores estará presente.Tal tipo de segregação é uma das conceituadas por Tereza Pires Caldeira (2000), que propôs uma periodização para o espaço urbano de São Paulo, ao longo do século $X X$, e identificou três formas diferentes de expressão.

A primeira estendeu-se por um período que abrange o final do século XIX até os anos 1940 e produziu uma cidade concentrada, na qual os diferentes grupos sociais se comprimiam numa área urbana pequena e estavam segregados por tipos de moradia.

O segundo padrão de urbanização denominado centro-periferia, dominou o desenvolvimento da cidade entre 1940 e 1980. Tem como características principais a dispersão, ao invés da concentração; a separação das classes sociais no espaço da cidade (a classe média e alta nos bairros centrais com boa infraestrutura e os pobres vivendo nas precárias e distantes periferias); a aquisição da casa própria torna-se regra para a maioria dos moradores da cidade (ricos e pobres); e o sistema de transporte baseia-se no uso de ônibus para as classes 
trabalhadoras e automóveis para as classes média e alta. O padrão de segregação em questão estava apoiado no sistema viário, automóveis e ônibus, e consolidou-se, simultaneamente, com o processo em que São Paulo e sua região metropolitana se tornaram o principal centro industrial do país e o seu mais importante polo econômico. As novas indústrias, muitas delas metalúrgicas, localizavam-se na periferia da cidade e dos municípios circundantes, ao tempo em que o comércio e os serviços permaneceram nas regiões centrais, não apenas no velho centro, mas também próximo às novas áreas de residência das classes média e alta em direção à zona sul da cidade.

De acordo com autora, há uma terceira forma de ocupação que vem se configurando desde os anos 80 e mudando, consideravelmente, a cidade e a sua região metropolitana. Sobrepostas ao padrão centro-periferia, as transformações recentes estão criando espaços, onde os diferentes grupos sociais estão muitas vezes próximos, no espaço local, mas separados por muros e tecnologias de segurança, e tendem a não interagir em áreas comuns (CALDEIRA, 2000).

A mesma autora considera que, em 2000, São Paulo era uma região metropolitana mais diversificada e complexa do que o fora quinze anos antes, quando o modelo centro-periferia era suficiente para descrever seu padrão de segregação e desigualdade social. Uma combinação de processos causou sua transformação, entre eles a reversão do crescimento demográfico; a recessão econômica, a desindustrialização e a expansão das atividades terciárias; a melhoria da periferia combinada com o empobrecimento das camadas trabalhadoras, o deslocamento de parte das classes média e alta para fora do centro; e ampla difusão do medo do crime que levou pessoas de todas as classes sociais a buscar formas mais seguras de moradia. Destaca, contudo, que a decisão de se isolar pela construção de muros, cercas eletrificadas, segurança, fechando bairros inteiros e, também, construindo condomínios fechados vai além do medo da violência (CALDEIRA, op.cit.). Esse é o tipo que Lévy e Lussault (2003) consideram segregação. Ele vem sendo estudado pelos 
geógrafos (OLIVA, 2004; SPÓSITO, 2007 e MELGAÇO, 2010) e observa-se que tem se instalado em diferentes municípios brasileiros.

Flávio Villaça $(1998,2003)$ também pesquisou sobre segregação e destacou a mediação do espaço na estruturação das cidades, não como mero receptáculo das práticas socioeconômicas, políticas e ideológicas. Sentencia que não se trata apenas de partir do social para explicar o espacial, mas é importante também partir do espaço para explicar o social. Assim, para o autor, a segregação é uma forma de exclusão socioeconômica que se manifesta no espaço

Para ele, há segregações das mais variadas naturezas na metrópole brasileira, em que se sobressaem a de classes e de etnias ou nacionalidades. Seu estudo concentrou-se na segregação das classes sociais, devido a implicações mais profundas sobre a estrutura urbana das nossas metrópoles. Entende como segregação "[...] um processo segundo o qual diferentes classes ou camadas sociais tendem a se concentrar cada vez mais em diferentes regiões gerais ou conjuntos de bairros da metrópole" (VILLAÇA, 1998, p.142). O que determina em uma região a segregação de uma classe é a concentração significativa dessa classe mais do que em qualquer outra região geral da metrópole.

Assinala que o padrão mais conhecido de segregação metropolitana brasileira é o de centro $x$ periferia, onde o primeiro é dotado da maioria dos serviços urbanos públicos ou privados, e ocupado por classes de alta renda. A outra, subequipada e distante, é ocupada, predominantemente, pelos excluídos. Essa segregação entre centro e periferia pode ser considerada por classes, em que se evidencia a dimensão de luta.

Ressalta que "[...] a segregação é um processo dialético, em que a separação de uns provoca, ao mesmo tempo e pelo mesmo processo, a segregação de outros" (Ibid., p. 148). Aponta, ainda, a acessibilidade ao centro e, posteriormente, a posição dentro da estrutura urbana como fatores predominantes na definição da localização das camadas de alta renda em nossas metrópoles, sendo mais importantes que o sítio natural atraente. 
De acordo com essa visão, como a segregação é um mecanismo de dominação e de exclusão, ela impede ou dificulta o acesso a serviços, benefícios, direitos ou vantagens, públicos e privados. $O$ resultado é que os equipamentos e serviços urbanos são mais acessíveis a uns do que a outros, considerando-se a acessibilidade em termos de tempo e custo de deslocamento no espaço urbano (VILLAÇA, 2003).

O controle da produção e consumo do espaço urbano exercido pela classe dominante, que é relativa ao subespaço em que está inserida, se dá através do controle de três esferas. Uma esfera é a econômica em que se destaca o controle do mercado imobiliário que produz os bairros da classe dominante no local onde ela deseja. Outra esfera é política em que ocorre o controle do Estado, que, no tocante ao espaço urbano, se dá por meio da localização da infraestrutura urbana, da localização dos aparelhos do Estado e da legislação de uso e ocupação do solo. Finalmente a classe dominante desenvolve toda uma ideologia a respeito do espaço urbano, que visa auxiliar a dominação e torná-la aceitável pelos dominados (VILLAÇA, 1998).

O conceito proposto por Flavio Villaça foi aplicado em diferentes metrópoles brasileiras, entre elas a RMSP. Nesta, identificou a área, que denomina de quadrante sudoeste, como aquela em que há maior concentração de bairros de classe média e acima da média. Corresponde, também, a mais da metade das famílias dessas classes e à totalidade dos bairros de alta renda. Paralelamente, os mais pobres se distribuíam pelo restante da cidade e na sua periferia (VILLAÇA, 2003).

A relevância da instância espacial ressaltada por Flavio Villaça, que contribuiu para embasar sua pesquisa, advém, dentre outros autores, de diferentes geógrafos, entre eles Milton Santos. Deste, ressalta a localização e a acessibilidade, questões importantes na definição da segregação. Os conceitos fazem parte da obra de Santos, intitulada o Espaço do cidadão (1993), na qual não emprega especificamente o termo segregação, contudo, o conteúdo relaciona-se diretamente a ele. 
Para o autor, o espaço vivido, à mercê do jogo do mercado e fomentado pelas ações do Estado, consagra desigualdades e injustiças que resultam, em sua maior parte, num espaço sem cidadãos. Lembra que, ao observar o mapa do Brasil, é fácil constatar áreas desprovidas de serviços essenciais à vida social e individual. Situações que não diferem as plantas das cidades, nas quais as periferias, embora apresentem expressiva densidade demográfica, tais serviços estão igualmente ausentes. Assim, ignoram-se as pessoas que lá habitam.

Conforme Santos (op.cit.), a repartição espacial das classes sociais ocorre em nível nacional, regional, mas, sobretudo, na cidade. Aos diferenciais de renda agregam-se as desigualdades territoriais e um interage com outro, potencializando-os. Os acessos aos bens e serviços essenciais, públicos e até mesmo privados, são diferenciados e contrastantes, os quais uma maioria de brasileiros, no campo e na cidade, acaba sem tê-los, seja porque simplesmente não há na área, seja porque não podem ser alcançados, por questão de tempo e/ou dinheiro.

Ressalta que a relação entre a fração do espaço e a fração da sociedade segundo níveis de renda não fundamenta uma explicação sobre as desigualdades, mas acaba por ser o seu resultado. Muitas vezes, indivíduos que dispõem de condições equivalentes de capital, de formação cultural e de capacidade física, ocupando o mesmo tipo de atividade, podem ser dotados de desigualdades em função dos diferentes pontos do espaço em que se localizam. Destaca, entretanto, que na maioria das vezes, a distribuição distinta pelo espaço é por conta de razões econômicas.

Assim, segundo Santos (op.cit.), há duas circunstâncias que explicam a distribuição da pobreza no espaço. Uma é identificar por que uma determinada organização do espaço conduz a uma concentração da riqueza em poucas mãos e é criadora de pobreza. Outra circunstância se refere aos casos extremos de imobilidade.

A imobilidade é vivida, em todas as cidades, por uma parcela da população que não dispõe de meios para mudar de casa e de bairro, o que 
explica a sua pobreza. Como o bairro de sua residência não conta com os serviços públicos e comercializa serviços privados a alto preço, obrigam os residentes a pesadas despesas com transporte caso queiram acessar os serviços essenciais.

Para cada cidade ou espaço rural, os dados objetivos (entre eles os salários, os preços, a qualidade e a quantidade da informação e os serviços oferecidos) e os dados reais ou aparentemente subjetivos (noções de bem-estar, perspectivas para o futuro, sentimento de participar nas decisões), que definem uma situação de pobreza, são por demais dispares; com efeito, existem num mesmo país diferentes situações de pobreza.

De acordo com Santos (1993), sob a ótica geográfica, o estudo da pobreza, ou dos seus lugares privilegiado, permite ainda outras duas abordagens. Uma considera a situação do homem enquanto produtor, consumidor ou exclusivamente enquanto cidadão no interior de um espaço não uniforme, onde o acesso aos mercados se distingue segundo a distribuição da rede de transportes, de repartição da produção e do aparelho de distribuição, dos custos e dos preços correspondentes. Tal abordagem conduz a uma interpretação baseada no conceito de acessibilidade, que distingue os espaços. Essa abordagem é completada pela segunda, em que parâmetros externos ao lugar, muitas vezes, determinam uma estrutura interna específica a cada ponto do espaço.

As condições existentes nesta ou naquela região determinam a desigualdade no valor de cada pessoa, contribuindo, tais distorções, para que o homem passe, literalmente, a valer em função do lugar onde vive. Essas distorções devem ser corrigidas, em nome da cidadania.

Como ficam tais desigualdades com o período da Globalização?

Segundo Santos e Silveira (2001) o conceito de espaço ou meio técnico-científico e informacional está no cerne da compreensão do processo de globalização. Espaço que gera uma globalização perversa por não atingir a todos de forma igualitária, sendo, portanto, segregadora. Para Santos (1988), é perversa porque concentra e centraliza a economia 
e o poder político, pela cultura de massa, pela cientificização da burocracia, pela centralização agravada das decisões e da informação, fatores esses que embasam um acirramento das desigualdades entre os países e entre as classes sociais, assim como da opressão e desintegração do indivíduo.

Os objetos modernos, baseados na técnica, na ciência e na informação, apresentam intencionalidades ditadas pela produção material ou imaterial, que criam espaços exclusivos no território. Esses espaços em extensão são minoritários, contudo, são espaços dominadores dos processos econômicos e políticos, cuja lógica implacável se sobrepõe e comanda os demais subespaços quantitativamente dominantes na paisagem, mas qualitativamente subordinados quanto às funções. Essa segregação espacial resulta no uso corporativo do território, que impede que a cidade seja considerada como um abrigo de todos (SANTOS, 1994b).

Silveira e Santos (2001) discutem essa segregação como desigualdades territoriais para formação socioespacial brasileira, que tem como fundamento um número de variáveis bem mais vastos no presente, cuja combinação produz uma enorme gama de situações de difícil classificação. Diante disso, propõem alguns pares dialéticos para exame do território: zonas de densidade e de rarefação, a fluidez e a viscosidade do território, os espaços da rapidez e da lentidão, os espaços luminosos e os espaços opacos. Tais características geram as novas lógicas na relação centro-periferia para o Brasil.

Sobre zonas de densidade e de rarefação, os autores consideram que há no território diferenças de densidades em relação aos objetos, às coisas, aos homens, ao movimento das coisas, das informações, do dinheiro e das ações. Advertem, entretanto, que tais densidades vistas apenas como números, são apenas indicadores que revelam e escondem, simultaneamente, uma situação e uma história (SANTOS; SILVEIRA, 2001). 
A partir de Santos e de Silveira $(2001)^{5}$, Maria Adélia A. de Souza (2002) registra que as densidades técnicas, instaladas diferentemente pelo território, assim como as informacionais, que podem envolver maior ou menor densidade de leis, normas, regras reguladoras da vida coletiva, estão, principalmente, a serviço das forças hegemônicas e do Estado. Esses agentes regulam as ações que definem as novas realidades espaciais e aprofundam as desigualdades e as diversidades espaciais. Nesse sentido, quando há maior densidade técnica e informacional definem-se como espaços luminosos, em oposição aos espaços opacos, em que tais densidades são rarefeitas.

Para Santos (1994b), os espaços opacos são aqueles constituídos pelos os objetos preexistentes, envelhecidos e tecnicamente menos evoluídos, que são considerados não funcionais aos modos de operação e comando dos atores hegemônicos, se comparado com as áreas luminosas, espaços racionalizados e racionalizadores, espaços da fluidez e da competitividade, ajustados aos propósitos mais perversos da globalização.

Souza (2002) acrescenta que os espaços luminosos são os que atraem atividades com maior conteúdo de capital, tecnologia e organizacional e são os espaços obedientes aos interesses das empresas. Ressalta que esses espaços são monitorados externamente e implicam na ingovernabilidade dos lugares.

Com relação à fluidez, Santos (1997, p. 218) registra que "[...] Uma das características do mundo atual é a exigência de fluidez para a circulação de idéias, mensagens, produtos ou dinheiro, interessando aos atores hegemônicos".

Segundo Silveira $(1996)^{6}$, citado por Souza (op.cit.) a fluidez e a viscosidade são as características do território que distinguem os países.

\footnotetext{
${ }^{5}$ SANTOS, Milton e SILVEIRA, Maria Laura. O Brasil-Território e sociedade no início do século XXI. Rio de Janeiro- São Paulo: Record, 2001.

6 SILVEIRA, M. L. Um país, uma região. Fim de século e modernidade na Argentina. 1996. 379f. Tese (Doutorado em Geografia Humana) - Departamento de Geografia - Faculdade de Filosofia Letras e Ciências Humanas, Universidade de São Paulo da USP, São Paulo, 1996,
} 
Trata-se dos sistemas de engenharia que produzem os movimentos, interessando diretamente à divisão territorial do trabalho. Destaca que "[...] nos países continentais, como o Brasil, esses processos de implantação dos sistemas de engenharia (infraestruturas, sistemas viários) são seletivos e, portanto, segregadores (SOUZA, op.cit., p.4)".

Santos e Silveira (2001) distinguem a fluidez entre efetiva e virtual. Esta é medida em função da presença dos respectivos sistemas de engenharia. Ressaltam, contudo, que a densidade viária nem sempre assegura fluidez, que só se efetiva a partir do uso das vias.

A densidade viária se relaciona mais com nexos da economia e do mercado, principalmente, e não com a maioria da população, de acordo com Souza (2002). Assim, pode-se inferir que o Estado governa mais para o interesse hegemônico do que para a sociedade brasileira, pois tem sido muito expressivo o processo de tecnificação do território brasileiro, nos últimos anos.

Santos e Silveira (2001) ainda distinguem os espaços da fluidez e da rarefação entre aqueles subespaços onde há uma grande circulação, em oposição àqueles onde esse fenômeno é menos representativo.

Com base nos autores, para Souza (op.cit.) o território da rapidez reflete o mandar, que comanda o território como um todo, enquanto que território da lentidão envolve o fazer, a obediência. A rapidez refere-se mais aos veículos, transportes públicos em que sob a ótica social intensifica a vida de relações econômica e sócia cultural. Tais características diferenciam-se, conforme a divisão territorial do trabalho.

Sintetiza a autora:

Rapidez e fluidez são características da sangria do território em direção aos seus pontos de convergência, geralmente as grandes metrópoles. Por isso elas empobrecem, pois a sangria se dá com componentes que se destinam ao mercado internacional, portanto viabilizando os interesses externos, por vezes conflitantes com aqueles da sociedade brasileira. Caso contrário, como explicar o aprofundamento da desigualdade e da segregação socioespacial? (Souza, 2002, p.5). 
Assim, esses pares dialéticos propostos por Santos e Silveira (op.cit.) estão relacionados ao meio técnico-científico-informacional.

A partir desta explanação discutem-se os meios geográficos para Guarulhos e os conceitos de segregação e a operacionalização deles para área de estudo. 


\subsection{Formação territorial de Guarulhos}

\subsubsection{Meio natural}

Guarulhos até o final do século XVII era dominada pelo meio natural. O marco de sua fundação, 08 de dezembro de 1560, foi o aldeamento indígena promovido pelos jesuítas para a proteção da Vila de São Paulo de ataques indígenas (NORONHA, 1960).

Os primeiros habitantes, os índios Maromomi, nômades, não praticavam a agricultura, mantinham-se, principalmente, com a coleta do pinhão, da castanha da sapucaia e do mel silvestre, além da caça e da pesca. Eles foram aldeados, catequizados e usados para vários tipos de trabalhos (NORONHA, 1960; ROMÃO e NORONHA, 1980; OLIVEIRA et al, 2007).

De acordo com Milton Santos e Maria Laura Silveira (2001) no Brasil o meio em questão foi marcado pelos tempos lentos da natureza, que comandavam as ações de diversos grupos indígenas e pela instalação dos europeus, empenhados todos, cada qual a seu modo, em amansar esses ritmos.

Tal meio foi sucedido pelo meio técnico, que no Brasil abrangeu um longo período, em que gradualmente o ser humano buscou atenuar o império da natureza. Em Guarulhos compreendeu o período entre o início do século $X V I I$ e meados do século $X X$.

\subsubsection{Meio técnico pré-máquinas}

O meio técnico - pré-máquinas - referiu-se a primeira atividade econômica/comercial do município, a extração de ouro associada a escravidão indígena e negra. A descoberta ocorreu no final do século XVI, em 1597. Foram constituídas áreas de mineração que podiam ser formadas por canais, túneis, represas e frentes de lavras. As explorações 
esgotaram-se no século XIX, em 1812 (OLIVEIRA et al, 2007; AGUILAR et al, 2012).

Em tal momento no Brasil havia subespaços que evoluíam pelas suas relações com o mundo exterior (Portugal) (SANTOS e SILVEIRA, 2001). Esses subespaços em Guarulhos correspondiam aos garimpos de ouro localizados juntos aos morros e a serrania (NORONHA, 1960; ROMÃO e NORONHA, 1980), que faziam parte de um sistema técnico desenvolvido localmente para atender a produção.

Ainda hoje há registros dos locais que se praticavam as atividades ligadas a esse momento, que englobam objetos técnicos preservados, que são considerados importantes sítios arqueológicos, o que tem levado a estudos para viabilizar sua preservação (PINHEIRO, 2008).

A sucessão do meio técnico pré-máquinas foi feita pelo meio técnico baseado no uso das máquinas para a produção e a circulação ferroviária.

\subsubsection{Meio técnico baseado no uso das máquinas para a produção e a circulação ferroviária}

Nesse momento, em Guarulhos a produção passou a realizar-se junto às áreas de planícies, sobretudo, aquelas ligadas aos rios Tietê e seus mais importantes afluentes, Cabuçu de Cima e Baquirivu-Guaçu. Isso ocorreu por conta da exploração da argila, empregada no ciclo do tijolo cozido, em que a forma de produção artesanal, praticada desde o século XIX, coexistiu com a industrial. Esta surgiu em 1915 e prolongou-se até 1964. Conjugado desenvolveu-se o sistema de transporte fluvial e posteriormente o ferroviário (OLIVEIRA et al, 2007; OMAR et al, 2008).

A influência da imigração europeia foi importante nesse momento. Em 1912, Guarulhos contava com 7.000 habitantes, dos quais cerca de $30 \%$ eram estrangeiros e destes mais de 85\% eram italianos. Em 1940 a população atingiu 13.439 habitantes, sendo que os imigrantes correspondiam a $15 \%$, entre eles destacavam-se os portugueses $(30 \%)$, 
os italianos $(20 \%)$, os japoneses $(21 \%)$ e os alemães (13\%) (SANTOS, 2006).

Para Santos e Silveira (2001) os imigrantes europeus além de constituírem mão-de-obra qualificada, eram portadores de um modelo de consumo que conheceram ou almejavam obter nos países de origem. Segundo eles, tais fatores contribuíram para explicar o desenvolvimento industrial do começo do século XX.

Mencionam que esse momento para o Brasil foi até a década de 40, do referido século, quando novas condições políticas e organizacionais permitiram que a industrialização fosse impulsionada pelo poder público e o mercado interno ganhasse um novo papel, que se mostrou crescente, na elaboração de uma nova lógica econômica e territorial para o país.

A industrialização que resultou na hegemonia de São Paulo, Wilson Cano (1998) afirma que a década de 20 representou para São Paulo "um novo salto" de sua capacidade produtiva, não apenas quantitativa, mas significou grande avanço na diversificação estrutural de sua indústria, com inclusão de novos produtos e novos segmentos produtivos.

Em tal contexto, foram implantadas fábricas de bens de consumo em Guarulhos, estimuladas pelo mercado consumidor formado pela população urbana de São Paulo, que demandou, entre outros, matériaprima para as edificações ${ }^{7}$.

Como a produção estava direcionada principalmente para o município de São Paulo, em 1915 foi inaugurada a primeira indústria voltada à produção de telhas e tijolos, conjuntamente, foram inauguradas as primeiras estações de trem ${ }^{8}$ (ROMÃO e NORONHA, 1980).

A chegada da ferrovia até o centro de Guarulhos possibilitou a diversificação da economia local e o deslocamento do eixo produtivo para

\footnotetext{
7 Segundo dados do IBGE em 1872 o município de São Paulo tinha uma população total de 31.385, que em 1940 salta para 1.326.261 habitantes, destes 94,9\% eram urbanos.

${ }^{8}$ Em Guarulhos havia seis estações e uma parada do trem: Vila Galvão, Torres Tibagy, Gopoúva, Vila Augusta, Parada Sorocabanos, Estação Guarulhos (praça IV Centenário) e Base Aérea de São Paulo, em Cumbica (OMAR et al, 2008)
} 
outros bairros da cidade, principalmente para as regiões atendidas pelo trem. Este integrou Guarulhos a Capital e tornou-se a principal via de transporte de passageiros e de mercadorias do município (SANTOS, 2006; OMAR et al, 2008).

No início da década de 1930, chegaram às primeiras multinacionais, que se localizaram no bairro do Macedo e próximas as futuras instalações da Rodovia Presidente Dutra (NORONHA, 1960).

A tais objetos técnicos agregaram-se a energia elétrica e a rede de telefonia, que chegou em 1908. Em 1913 foi aprovada a lei que autorizava a Light \& Power a executar serviços de iluminação pública em Guarulhos por 30 anos. Foi inaugurada a luz elétrica em 1914 (OLIVEIRA et al, 2007). Somaram-se também as primeiras escolas, hospitais e biblioteca.

A partir de 1944, iniciou-se a vinda de milhares de migrantes nacionais para Guarulhos, entre eles nordestinos, mineiros, paranaenses (OLIVEIRA et al, op.cit.). Vindos principalmente para trabalharem em São Paulo e na construção da Base Aérea de Cumbica (1941) e da Via Dutra.

O Estado de São Paulo foi o maior receptor dos fluxos migratórios. Em 1940, seu fluxo acumulado de entrada bruta de imigrantes equivalia a $10,1 \%$ de sua população, cifra que aumentaria para $11,6 \%$ em 1950 (CANO, 1998).

Devido ao crescimento da cidade de São Paulo, a Base Aérea que se localizava no Campo de Marte, em Santana, foi transferida para Cumbica, Guarulhos. A Base, de propriedade do Ministério da Aeronáutica, foi estrategicamente construída próxima de onde já se iniciavam as obras da Dutra. Em 1980, a partir dessa área foram iniciadas as obras da construção do Aeroporto Internacional (SANTOS, op.cit.).

A partir da década de 50, esse subperíodo do meio técnico foi sucedido em Guarulhos, por aquele que é muito significativo para o entendimento da segregação socioespacial contemporânea. 


\subsubsection{O meio técnico e organizacional da produção industrial e da circulação rodoviária}

Para Guarulhos esse subperíodo caracterizou-se como uma transição entre o momento anterior e o próximo período. Considerou-se relevante compartimentá-lo em razão da inauguração da Rodovia Presidente Dutra (1951), evento muito significativo na estruturação do território guarulhense.

Nacionalmente, no pós-guerra, ocorre a integração nacional, por meio da construção de estradas de rodagem, à continuação do estabelecimento das ferrovias e a uma nova industrialização. Entre 1945 e 1950 a indústria brasileira ganha novo ímpeto e São Paulo confirmou-se como a grande metrópole fabril do país (SANTOS; SILVEIRA, 2001).

O termo industrialização deve ser entendido como processo social complexo, que engloba a formação de um mercado nacional, esforços de estruturação do território para torná-lo integrado, com a expansão do consumo em formas diversas, o que dinamiza o setor terciário e ativa o próprio processo de urbanização. Essa nova base econômica ultrapassou o nível regional e atingiu a escala do país; por isso a partir daí uma urbanização cada vez mais envolvente e mais presente no território ocorreu com o crescimento demográfico sustentado pelas cidades médias e maiores, além das capitais de estados (SANTOS, 1994a).

Em busca da integração territorial há investimentos do governo federal para expansão da rede rodoviária a partir da Segunda guerra mundial, que atendeu ao processo de industrialização associado aos grandes projetos nacionais. Sua criação correspondeu à configuração de uma nova circulação engendrada pela vida de relações do país a partir desse momento (SANTOS; SILVEIRA, op.cit.).

Desta forma, foi inaugurada a Via Dutra, pelo presidente Eurico Gaspar Dutra, em 1951. Constitui-se numa das mais importantes rodovias do País, responsável pela principal ligação rodoviária entre São Paulo e Rio 
de Janeiro. No final da década de 1950, no governo do presidente Juscelino Kubitscheck, entra em atividade a Rodovia Federal Fernão Dias, ligando São Paulo a Minas Gerais. Estas rodovias modificaram significativamente o fluxo de produtos, serviços e mão-de-obra entre os três maiores centros econômicos do país.

A tais expressivos sistemas de engenharia somaram-se outros resultantes do Plano de Metas, criado pelo o presidente Juscelino Kubitscheck, foram eles: no setor de energia, o aumento da potência elétrica instalada, a implantação da indústria automobilística, ampliação da infraestrutura, significativo crescimento na produção de petróleo, de alimentos e da indústria de base e avanço no processo de substituição de importações.

O trajeto daquelas rodovias passa pelo território de Guarulhos e trouxe um grande impulso e diversificação para a industrialização local, que se desenvolvia desde o período anterior e referia-se principalmente a exploração de tijolos. Destacou-se também a influência da Base Aérea, contígua a Via Dutra.

Também a esse sistema de objetos conjuga-se o processo de metropolização de São Paulo.

Segundo Paul Singer a grande valorização do solo na capital paulista atraiu estabelecimentos industriais para os municípios limítrofes servidos pelas principais estradas de rodagem (SINGER, 1977).

Com isso, em Guarulhos, entre 1953 e 1956, o número de indústrias cresceu mais de seis vezes com a constituição de 143 novos estabelecimentos, que de 27 em 1953 foram para 170 em 1956 (SANTOS, 2006). Conforme o autor (Ibid., p.158), "[...] Guarulhos teve seu território tomado pela instalação de um expressivo conjunto industrial de pequeno, médio e grande porte. Eram especialmente indústrias do setor de transformação".

Outros objetos técnicos passaram a constituir o território entre eles a Santa casa de misericórdia de Guarulhos (1951), a primeira agência 
bancária (1954), agência do correio (1955), Caixa econômica federal (1960) e bombeiros (1964).

Colaborou para a industrialização o êxodo rural, que foi responsável pelo exército de reserva de força de trabalho (SINGER, 1973). Para o autor, a migração nacional não é justificada apenas pela industrialização, assim como para Santos e Silveira (2001), em que muitas pessoas são expulsas do campo para as cidades, principalmente para as maiores, devido à persistência de uma estrutura fundiária defeituosa na maior parte do território brasileiro, onde uma grande quantidade de terras pertence a uma minoria de pessoas.

Em 1950 o município contava com 35.522 pessoas, das quais 53\% correspondiam à população rural. Esta em 1960 foi reduzida a 23\% do total de moradores. Além da preponderância da população urbana, destaca-se que o total de habitantes quase triplicou em uma década e atingiu 101.273 habitantes. É importante ressaltar que continuou a influencia da migração nacional no adensamento populacional de Guarulhos.

$\mathrm{Na}$ Figura 06 foi representado o adensamento urbano do município de 1958 a 2002, com base no terreno ocupado. Nela identifica-se que até 1958, o adensamento concentrou-se na parte sudoeste, sobretudo, desde o desenvolvimento do meio técnico e organizacional baseado no uso das máquinas na produção e circulação, isto é, as primeiras indústrias e a ferrovia. A porção leste apresentava reduzidas manchas de ocupação, algumas remontam ao meio técnico pré-máquinas.

Ressalta-se, contudo, que a partir desse momento o eixo produtivo do município, que se localizava na região central, definido pela Estrada de Ferro Sorocabana, começou a se transferir para Cumbica, zona sul e leste, nas proximidades da Rodovia Presidente Dutra.

O período em que o meio técnico e organizacional dominava foi sucedido pelo meio técnico-científico-informacional, que se subdividiu com o meio técnico-científico (SANTOS e SILVEIRA, 2001). 


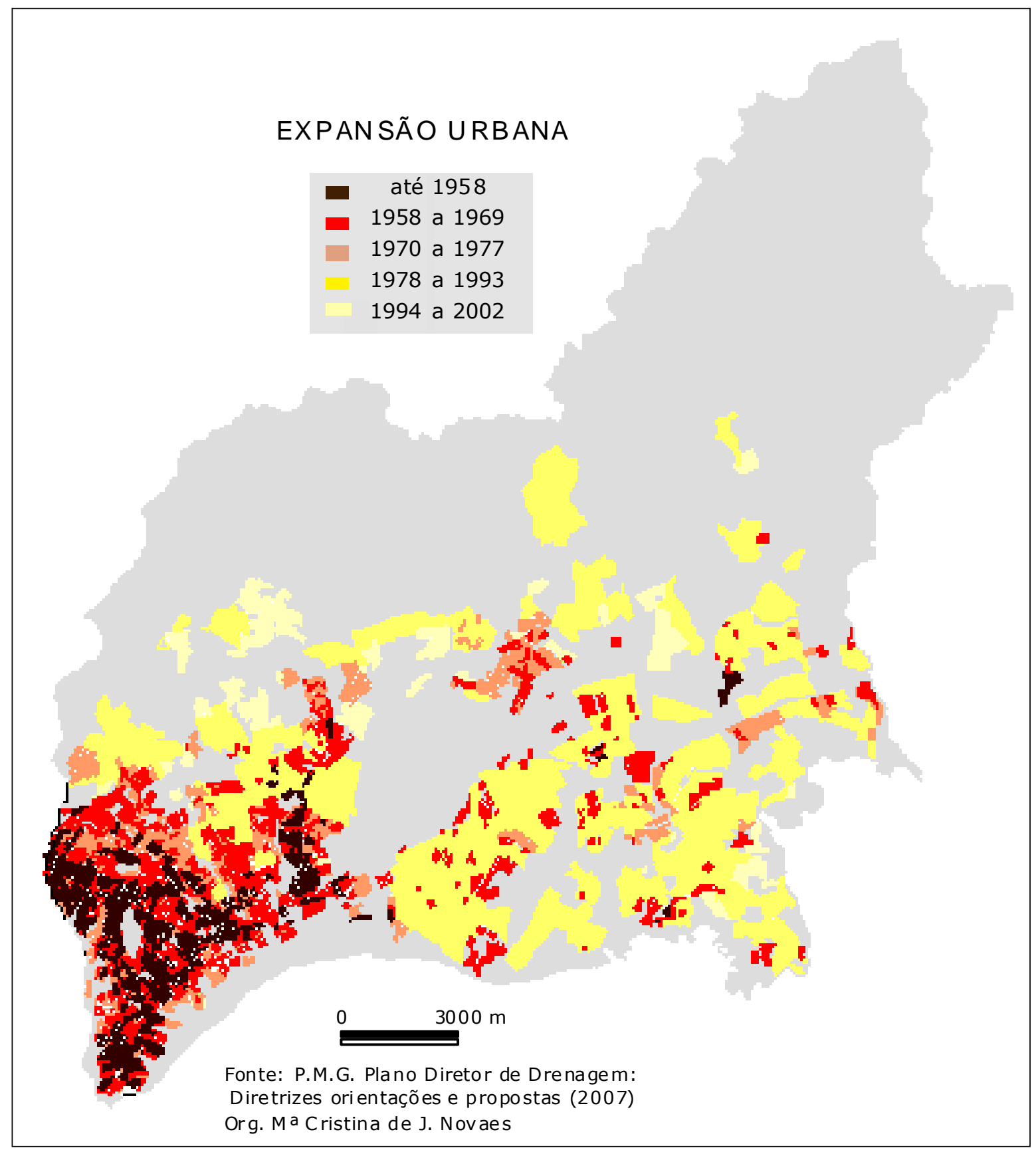

Figura 06 - Expansão urbana de Guarulhos

\subsubsection{Meio técnico-científico}

O meio técnico-científico é o momento em que territórios cada vez mais amplos agregam conteúdos de ciência e técnica, tanto para sua construção como reconstrução. Iniciou-se, praticamente, após a Segunda Guerra Mundial, e sua afirmação, incluindo os países do terceiro mundo, 
aconteceu, realmente, nos anos 70 (SANTOS, 1994a; SANTOS; SILVEIRA, 2001).

O Golpe Militar foi considerado um marco para o meio técnico-científico no Brasil, por ter criado as condições de uma rápida integração do país a um movimento de internacionalização, que aparecia irresistível em escala mundial, segundo Santos e Silveira (2001). Para Guarulhos, compreendeu o intervalo de tempo entre o Golpe Militar (1964) e a inauguração do Aeroporto internacional (1985).

A economia se desenvolveu para atender a um mercado consumidor em célere expansão e para responder a uma demanda do exterior. $O$ país passou a ser exportador, tanto de produtos agrícolas não tradicionais como a soja e cítricos, parcialmente beneficiados, antes de ser enviados para o estrangeiro, quanto de produtos industrializados.

Também impulsionou o avanço da industrialização o aumento da população, a classe média ampliada e a sedução dos pobres por um consumo diversificado e ajudado por sistemas extensivos de crédito (SANTOS, 1994a).

Legitimada pela ideologia do crescimento, a prática de modernização que o Brasil apresentou desde o chamado milagre econômico, conduziu o país a enormes mudanças econômicas, sociais, políticas e culturais apoiadas no equipamento moderno de parte do território e na produção de uma psicoesfera ${ }^{9}$ tendente a aceitar tais mudanças como um sinal de modernidade (SANTOS, 1994a; 2009a).

É importante ressaltar que a ideologia de modernização e racionalidade a qualquer preço não se limitou apenas à industrialização, estendendo-se, também, para o setor público e atingindo esferas que até então não tinham sido tocadas ou o foram apenas indiretamente, como

9 Para SANTOS (1994b) o meio técnico científico é formado pela tecnoesfera e psicoesfera. "[...] A tecnoesfera é o resultado da crescente artificialização do meio ambiente. A esfera natural é crescentemente substituída por uma esfera técnica, na cidade e no campo. A psicoesfera é o resultado das crenças, desejos, vontades e hábitos que inspiram comportamentos filosóficos e práticos, as relações interpessoais e a comunhão com o Universo (p.32)". 
por exemplo, a manipulação da mídia, a organização e o conteúdo do ensino em todos os níveis, a vida religiosa, as relações de trabalho, e afins (SANTOS; SILVEIRA, 2001).

O conjunto, formado pelas novas condições materiais e pelas novas relações sociais, cria as condições de operações de grandes empresas, nacionais e estrangeiras, que age na esfera da produção, da circulação e do consumo e cujo papel direto e/ou por intermédio do poder público, no processo de urbanização e na reformulação das estruturas urbanas, sobretudo nas grandes cidades, permite falar de urbanização corporativa e de cidades corporativas.

Um dos usos corporativos do território ocorreu a partir da primazia do sistema de produção e circulação rodoviária em relação à ferroviária, que passou a dominar a configuração territorial como um todo, inclusive a configuração urbana. No caso de Guarulhos, a ferrovia, que estava conjugada com as primeiras indústrias, foi suprimida em 1965.

O sistema de circulação rodoviário atende em especial as indústrias. De acordo com os dados do IBGE, em 1969, havia diversas multinacionais, que, junto às nacionais, somavam 791 estabelecimentos industriais no município de Guarulhos. Desse número, 27\% correspondiam a materiais elétricos e de comunicações, $14 \%$ à mecânica, $10 \%$ à metalúrgia, $7 \%$ produtos alimentares, $7 \%$ a material de transporte e 0 restante a outros tipos de empresas. Maria Adélia A. de Souza (1976) destacou as especializações industriais no Estado de São Paulo, junto ao sistema de circulação, entre elas as do Vale do Paraíba, associadas ao percurso da Rodovia Presidente Dutra, que correspondiam, parcialmente, às indústrias de Guarulhos.

Sobre as multinacionais no Brasil, Paul Singer (1989) afirma que elas se expandiram, na segunda metade da década 50, principalmente em função do mercado interno, ao passo que, após 1964, passaram a ser vistas como um caminho alternativo de industrialização, voltado para fora, ao contrário da substituição de importações que é, por definição, voltada para dentro. A partir de 1969, sobretudo, o Governo passou a oferecer um 
volume de incentivos de tal ordem às exportações de manufaturados que as multinacionais tiveram acelerado o seu crescimento. Assim, disseminaram-se por quase todos os ramos de atividade, o que implicou um sensível aumento da dependência financeira e tecnológica do exterior.

Como foi destacado, após a Segunda guerra mundial, de modo especial depois de 1960, através das rodovias, São Bernardo, Diadema, Guarulhos e Osasco, passaram, em momentos diferentes, por um rápido processo de industrialização (KOWARICK,1979), que foi acompanhado pelo aumento do exército de reserva, em que o componente migratório teve significativa participação.

As migrações intensificaram-se para o Estado de São Paulo que, por ser o mais rico dos Estados, teve, naturalmente, maior poder de atração. Entre 1970 e 1980 a RMSP recebe, sozinho, 37\% do total de migrantes do País, vindos principalmente da Bahia, de Minas Gerais e Pernambuco (SANTOS; SILVEIRA, 2001).

Nesse contexto, a população de Guarulhos apresentou elevado crescimento, iniciado a partir do meio técnico discutido anteriormente. Assim, em 1960 a população era de 101.273 habitantes, tendo, depois de dez anos, ultrapassado o dobro desse número, chegando a 237.900 moradores e, mantendo praticamente o mesmo ritmo, atingiu 532.726 pessoas em 1980 (IBGE, 1960, 1970 e 1980). Com isso, a taxa média de crescimento populacional por ano entre 1960 e 1970 foi de $8,92 \%$ e de $8,4 \%$ entre 1970 e 1980 . A migração contribuiu, significativamente, para esse aumento. Em 1970 mais da metade (57\%) dos habitantes não tinha nascido no município, percentual que, em 1980 , correspondia a $71,3 \%$ do total dos moradores (OLIVEIRA et al, 2007).

Ao processo de industrialização, somaram-se os deslocamentos dos trabalhadores em direção à periferia, o que resultou na expansão da área urbanizada da RMSP. Entre os anos 1940 e 1980, o processo de expansão periférica afetou a cidade de São Paulo e os demais municípios, que formaram uma conurbação, para constituir sua região metropolitana (CALDEIRA, 2000). 
Foi reproduzida uma coleção de mapas os quais mostram a expansão da mancha urbana do município de São Paulo (Figura 07). Ao correlacionar esses mapas com o da expansão urbana de Guarulhos (Figura 06), verifica-se que a área contínua entre os dois municípios limitava-se ao sudoeste de Guarulhos, até o final da década de 60. Na década seguinte, a ocupação de Guarulhos expandiu-se e formaram-se alguns núcleos, sobretudo, na parte leste do seu território, conforme se vê em 1972, na Figura 07 e entre 1970 e 1977, na Figura 06. Em 1983 (vide Figura 7), a ocupação guarulhense uniu-se à boa parte da zona leste da capital paulista. É importante lembrar que essa junção não é apenas das áreas territoriais, mas também de diferentes vínculos que se estabelecem entre os municípios, principalmente os socioeconômicos.

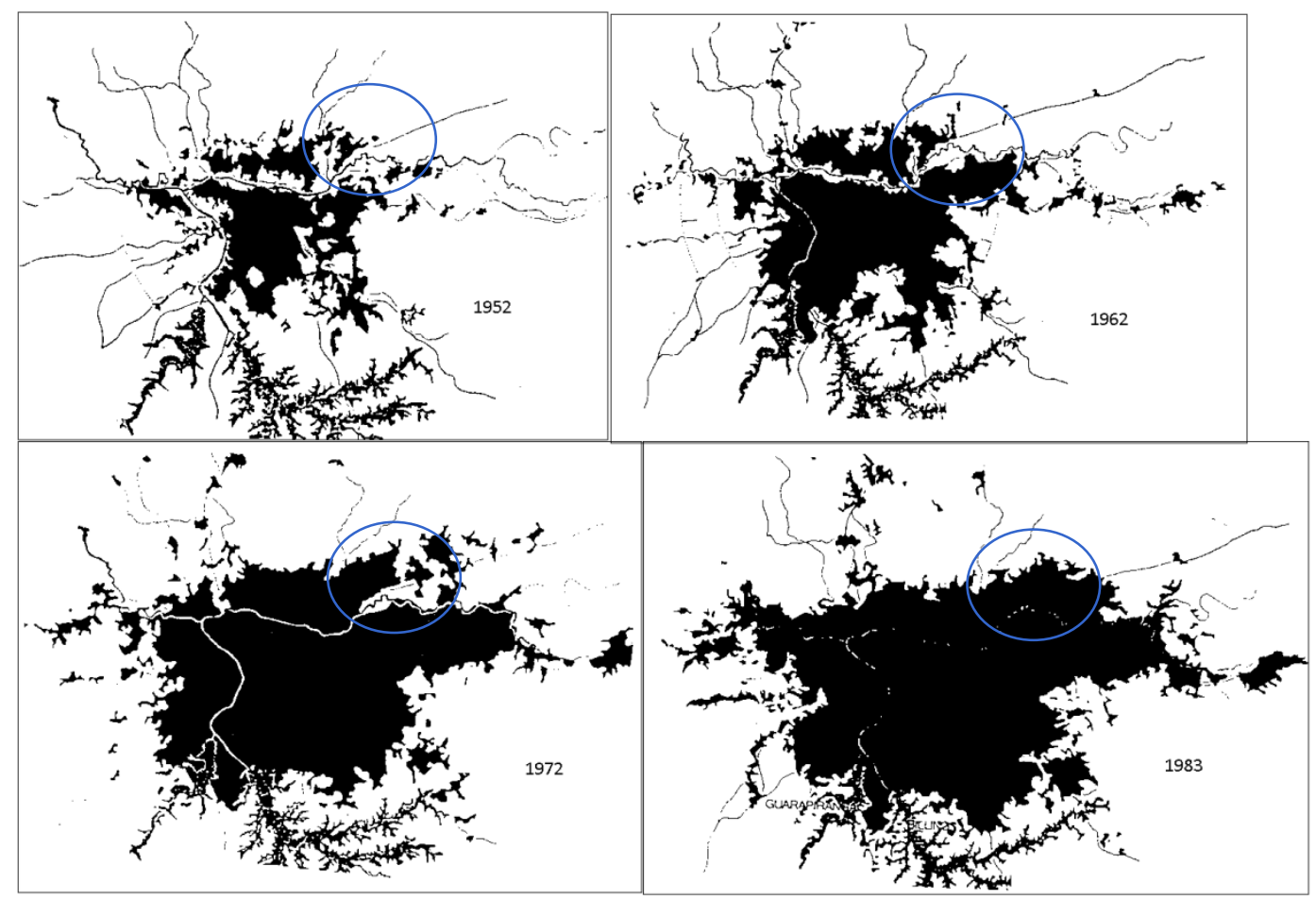

Figura 07 - Expansão da mancha urbana do município de São Paulo. Em destaque Guarulhos. Fonte: (SANTOS, 2009a).

Segundo Tereza P. Caldeira (2000) o crescimento da pobreza, combinado com melhores condições e terrenos mais valorizados na periferia da capital paulista, expulsou os mais pobres para os limites da 
cidade ou para outros municípios da RMSP. A autoconstrução tornou-se mais difícil e forçou uma considerável parcela da população mais pobre a viver em favelas ou em cortiços.

Lúcio Kowarick (1979) destaca que ao vertiginoso crescimento demográfico da Região metropolitana, conjugou-se o processo de retenção de terrenos à espera de valorização, o que levou ao surgimento de bairros cada vez mais distante. Com isso, as pessoas foram habitar áreas longínquas, afastadas dos locais de trabalho, tendo que enfrentar deslocamentos cada vez maiores. Acentuou-se o processo de criação de cidades dormitório, verdadeiros acampamentos desprovidos de infraestrutura. Assim, além do trabalho e da moradia, o sistema de transportes passou a ser um dos problemas cruciais para aquela população.

Tais constatações associam-se ao processo de ocupação territorial de Guarulhos. Além disso, como salienta o mesmo autor, à medida que os municípios industrializados se expandiam, criaram, por sua vez, a sua própria periferia que refletia, talvez ainda de forma mais dramática, os problemas socioeconômicos encontrados na capital (KOWARICK,1979).

Nesse sentido, Santos (2009a) registra que pelo fato de os municípios da RMSP formarem sua própria periferia, a análise deve ser cautelosa e também levar em consideração a burguesia local e sua segmentação socioprofissional, que induzem a uma segregação socioespacial e a uma valorização diferencial dos terrenos.

Sobre a formação da periferia em Guarulhos, Carlos J. Ferreira dos Santos (2006), em seu estudo demonstra que, além das determinações do processo de metropolização e dos modelos nacionais desenvolvimentistas, o desenvolvimento industrial e urbano de Guarulhos atendia aos interesses particulares dos chefes políticos locais e dos grupos sociais a que eles pertenciam e que representavam. Para tal afirmação, pesquisou sobre as origens sociais e econômicas de alguns prefeitos do município, a partir da década 40, tendo identificado vínculos dos 
dirigentes municipais com o setor imobiliário, comercial, industrial e de serviços locais.

Segundo o autor, vários bairros constituíram-se a partir das décadas de 50 e 60, resultantes de loteamentos promovidos pelo poder público municipal e por agentes sociais a ele vinculados. Sua análise partiu das Leis de Zoneamento, entre elas a promulgada em 1957, em que o Zoneamento foi alterado para acompanhar os constantes loteamentos que ocorriam. Em 1969, uma nova lei foi criada com o intuito de "ordenar o crescimento e ocupação do solo", incluindo, na zona urbana, vários bairros em direção à zona norte do município, onde se localiza a Serra da Cantareira (área preservada em parque e manancial). Tal zoneamento criou quatro Zonas de Expansão Urbana, com um elevado número de novos loteamentos, sendo a maioria distante do núcleo central de Guarulhos, que originaram, nas décadas de 1970 e 1980, a periferia metropolitana localizada em Guarulhos.

Enquanto poucos ganhavam com o crescimento econômico do município, a maioria da população se alojava em áreas sem infraestrutura elementar, o que é atestado por diferentes dados, entre eles o de que havia em Guarulhos, em 1987, 200.446 domicílios particulares permanentes, dos quais apenas $51 \%$ tinham ligação de água encanada e apenas $26 \%$ de rede de esgoto (SANTOS, 2009a).

Para Santos (1994a) e Kowarick (1982) as condições de vida de grande parte da população deterioraram-se, justamente quando a economia cresceu até uma significativa taxa de $10 \%$ ao ano, dando origem ao que muitos designam como o Milagre Brasileiro, o que não exclui o município de Guarulhos.

Como marco da transição do meio técnico-científico para o meio técnico-científico-informacional em Guarulhos, tomou-se como evento principal, a inauguração do Aeroporto internacional (1985). 


\subsubsection{Meio técnico-científico-informacional}

Para Milton Santos (1994a, 1994b, 1997), o meio técnico-científico-informacional corresponde à presença da ciência, da técnica e da informação nos processos de remodelação do território, essenciais às produções hegemônicas, que necessitam desse novo meio geográfico para sua realização. É a expressão geográfica da globalização, que constitui o ápice do processo de internacionalização do mundo capitalista, o qual, para ser entendido, há de levar em conta dois elementos fundamentais: o estado das técnicas e o estado da política, válidos para qualquer momento da história (SANTOS, 2000; SANTOS; SILVEIRA, 2001).

Segundo o autor, as técnicas são oferecidas como um sistema, que, atualmente, possibilita a unicidade entre elas, a convergência dos momentos, a cognoscibilidade do planeta e a mais-valia globalizada, que contribuem para a explicação da globalização atual (SANTOS, 2000).

A unicidade da técnica é dada pelo predomínio de um sistema técnico, que é a base material da mundialização. Desenvolveu-se, graças aos avanços da ciência no final do século $X X$, que produziu um sistema presidido pelas técnicas da informação, com base na cibernética, na informática e na eletrônica, que passaram a exercer um papel de elo entre as demais, unindo-as e garantindo a presença planetária desse novo sistema. Como a técnica da informação tem um papel preponderante sobre o uso do tempo, permite em todos os lugares a convergência dos momentos, garantindo a simultaneidade das ações e, por conseguinte, acelera o processo histórico. Esse sistema permite o conhecimento do planeta de forma extensiva e profunda, que é a cognoscibilidade planetária.

A existência de um motor único é possível, atualmente, por conta de a produção ser realizada em escala mundial, mediada pelas empresas mundiais, que competem ferozmente entre si, resultando na mais-valia globalizada. A competitividade é, nesse período, a mais guerreira de todas as ações, conforme SANTOS (1997), responsável pelas reorganizações, 
sociais, econômicas, políticas e, também, geográficas. Ao surgir uma nova família de técnicas, ela é apropriada pelos atores hegemônicos, enquanto que os não hegemônicos continuam empregando conjuntos menos atuais e menos poderosos.

Com isso, se um determinado ator não tem condições de utilizar as técnicas consideradas mais avançadas, passa a ter menor importância no período atual (SANTOS, 1997; 2000). Um mercado global empregando esse sistema avançado resulta numa globalização perversa, que poderia ser diferente se o seu uso político fosse outro (SANTOS, 2000). O sistema técnico hegemônico, formado por objetos e relações sociais mundializadas, é comandado pelas instituições supranacionais (Banco Mundial, FMI, BIRD, entre outras), grandes empresas e Estados (SANTOS, 1994b).

Em Guarulhos, a inauguração do Aeroporto (1985) constituiu um evento significativo na definição do meio técnico-científico-informacional, que também provocou mudanças importantes no território.

Assinalam Santos e Silveira (2001) que, na primeira metade do século $X X$, ocorreu à expansão da ferrovia e, a partir dos anos 50, o rearranjo da configuração territorial resultou, sobretudo, da expansão rodoviária e do desenvolvimento do transporte aéreo, que criam nodalidades de nova qualidade. São constatações que se associam à configuração territorial guarulhense, uma vez, que, como mencionado, a ferrovia foi extinta e as rodovias contribuíram para a modificação da configuração territorial, que sofreu novas alterações com a instalação do aeroporto.

O Aeroporto Internacional é um dos objetos hegemônicos presentes no território. A sua implantação, que inclui a zona aeroportuária, ocorreu de forma acelerada e, para tal, os demais usos existentes no território foram ignorados. Isso se depreende dos estudos realizados por Carlos J. Ferreira dos Santos (2006) e Nilton César de O. Gama (2009), que demonstram a extinção de áreas residenciais, industriais e viárias do 
entorno, mesmo que a comunidade local tivesse se mobilizado para diminuir os impactos sobre suas moradias.

Cabe lembrar, que a decisão de sua instalação no território foi uma ação conjunta dos governos federal e estadual. Os representantes municipais não se mobilizaram, embora se dissessem contrários ao empreendimento.

Reafirmando o caráter corporativo com que se instalam os objetos hegemônicos no território, apesar dos impactos negativos que chegaram com a instalação do aeroporto no território, as intervenções na infraestrutura do município preocuparam-se em garantir a acessibilidade até ele (GAMA, op.cit.). Em 1982, foi inaugurada a Rodovia Ayrton Senna que, junto com a Rodovia Dutra, foram interligadas ao aeroporto pela construção da Rodovia Hélio Schmidt.

A partir da conclusão do Aeroporto, que passou a ocupar posição no centro do município, com $14 \mathrm{~km}^{2}$, vários problemas se incorporaram ao cotidiano da população, como a ampliação das distâncias entre os bairros, a poluição atmosférica e sonora, inundações, a ausência de recuperação das áreas degradadas, superexploração do aquífero Baquirivu e ausência de retorno de impostos da área operada para o município. Soma-se, também, para parte dos habitantes vizinhos, a convivência com o medo de futuras desapropriações, advindas da possibilidade de expansão da área do aeroporto. Essa situação esteve presente quando foi cogitada a construção da terceira pista, decisão que, no momento, está suspensa. Contudo, essa indefinição sobre a ampliação de sua área, levou ao abandono do entorno, o que é mais um problema entre os diversos elencados.

Como mencionado, muitos loteamentos estabeleceram-se após a chegada da Via Dutra, conforme a Figura 06, os quais foram ocupados de forma intensa entre 1978 e 1993, sobretudo, nas partes norte, nordeste e leste do município. Essas ocupações significaram, em curto intervalo de tempo, mais que o dobro da superfície terrestre, que até então era adensada em Guarulhos. A partir da Tabela 01, depreende-se que o 
município recebeu um aporte populacional de mais de 250.000 habitantes, no período de 1980 a 1991, que resultou de taxa de crescimento anual de $3,62 \%$, bem menor do que os índices das décadas anteriores, quando eram superiores a 10\%, entre 1940 e 1960, e além de 8\%, entre 1960 e 1980.

Tabela 01 - Crescimento Populacional de Guarulhos - 1940 a 2010

\begin{tabular}{|c|c|c|c|c|c|}
\hline Ano & $\begin{array}{c}\text { População } \\
\text { absoluta }\end{array}$ & Período & $\begin{array}{c}\text { Crescimento } \\
\text { Populacional } \\
\text { anual (\%) }\end{array}$ & $\begin{array}{c}\text { Incremento } \\
\text { Populacional } \\
\text { absoluto }\end{array}$ & $\begin{array}{c}\text { Taxa anual } \\
\text { de migração } \\
\text { (por mil \%) }\end{array}$ \\
\hline 1940 & 13.439 & - & - & - & - \\
\hline 1950 & 35.522 & $40-50$ & 10,21 & 22.083 & - \\
\hline 1960 & 101.273 & $50-60$ & 11,05 & 65.751 & - \\
\hline 1970 & 237.900 & $60-70$ & 8,92 & 136.627 & - \\
\hline 1980 & 532.726 & $70-80$ & 8,4 & 294.826 & 10,96 \\
\hline 1991 & 787.866 & $80-91$ & 3,62 & 255.140 & 17,08 \\
\hline 2000 & 1.072 .717 & $91-00$ & 2,49 & 284.851 & 0,04 \\
\hline 2010 & 1.221 .979 & $00-10$ & 1,41 & 149.262 & \\
\hline
\end{tabular}

Fonte: IBGE e SEADE.

A Tabela 01 revela também que, em 1980, havia 532.726 habitantes no município, os quais, segundo a Figura 08, estavam concentrados nos bairros situados a oeste do Aeroporto, que conjuntamente apresentam-se na anamorfose bem mais volumoso do que os bairros da porção leste. $A$ partir da Figura 09, visualiza-se que, apesar de recentemente ocupada, a porção leste do município já abrigava o bairro mais populoso que era Cumbica, com 41.159 habitantes e o terceiro, o chamado Pimentas com 28.653 moradores. Na mesma figura, observa-se que o bairro do Picanço, vizinho ao Centro, com 37.021 pessoas tinha a segunda maior população, a quarta era a de Vila Galvão com 28.249, sucedido pelo Taboão com 25.036 habitantes.

Em 1991, conforme a Tabela 01, com 787.866 habitantes o município passou a ser o segundo mais populoso da RMSP, perdendo 


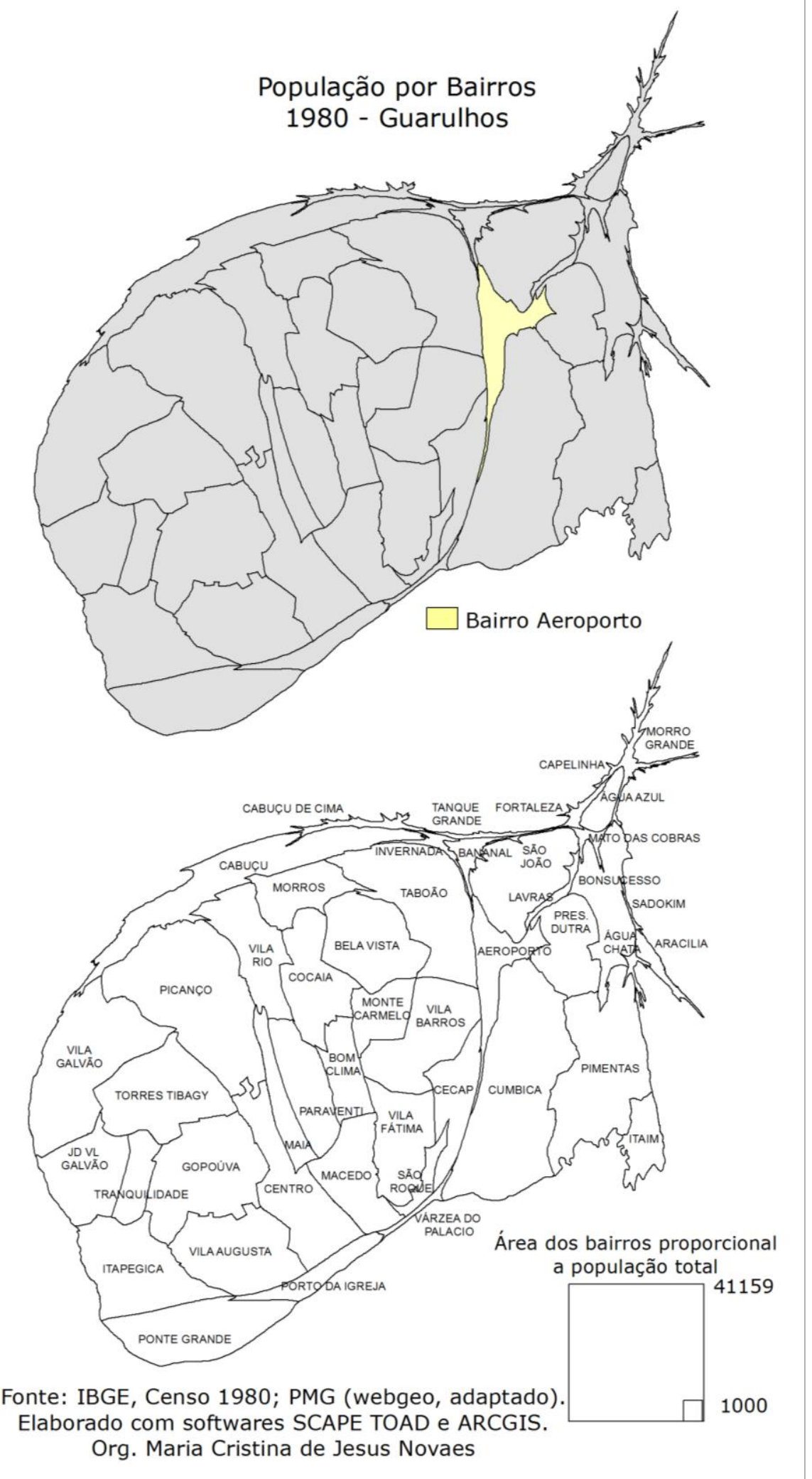

Figura 08 - População por Bairros - Guarulhos (1980). 


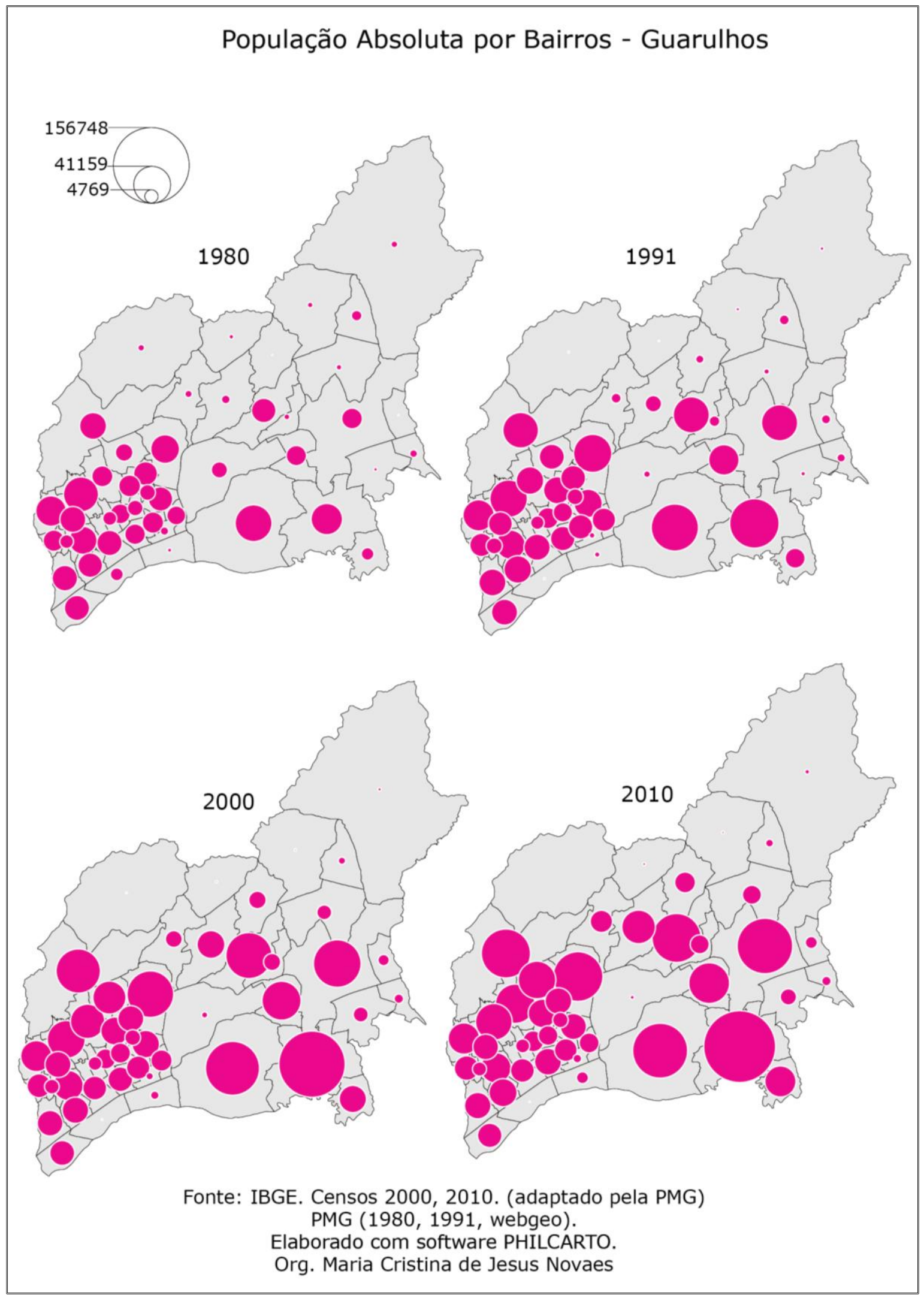

Figura 09 - População absoluta por bairros - Guarulhos (1980, 1991, 2000 e 2010). 
apenas para a capital paulista. A população mantinha-se concentrada na porção oeste do Aeroporto, em que a maioria dos bairros teve taxa de crescimento inferior a $4 \%$; os índices mais elevados, contudo, referiam-se aos bairros que se situam a leste e a nordeste do aeroporto, Pimentas, Cumbica, Bonsucesso e São João, que superaram a taxa de $8 \%$, conforme as Figuras 09 e 10.

Ainda, apresentaram aumento significativo, entre 4 e $8 \%$, o bairro do Presidente Dutra e, entre os que se situam a oeste do aeroporto, 0 Cabuçu e o Taboão. Na Figura 09, visualiza-se a população absoluta por bairros, o Pimentas abrigava 73.178 pessoas em 1991, quando passou a ser o mais populoso do município, seguido de Cumbica com 67.440, do Taboão com 44.212, do Picanço com 42.595 e do Bonsucesso com 39.613 pessoas. Outra informação relevante é que, entre 1980 e 1991, alguns bairros apresentaram queda no número de seus habitantes, entre eles o Centro e o bairro do Aeroporto, que teve a população diminuída, em função das desapropriações realizadas para a instalação do sistema de objetos, agregado ao aeroporto.

Entre 1994 e 2002, de acordo com a Figura 06, alguns bairros situados a norte e a nordeste constituíram-se os preferenciais para os novos habitantes, destacando aqueles localizados vizinhos às áreas de preservação. O período corresponde, aproximadamente, na Tabela 01 entre os anos de 1991 e 2000, em que o incremento populacional foi de 284.851 pessoas, resultando na taxa de crescimento médio anual de 2,49\%, inferior à década anterior, vide figura 11. Assim, em 2000, Guarulhos atingiu mais de um milhão de habitantes (1.072.717), quando a maior expansão continuou ocorrendo nos bairros situados na parte leste da cidade, como se observa na figura 10, sobressaindo-se, novamente, com as taxas mais elevadas, Pimentas (133.611 habitantes), Bonsucesso (68.762 habitantes) e São João (64.734 habitantes), mostrados também na Figura 09. 


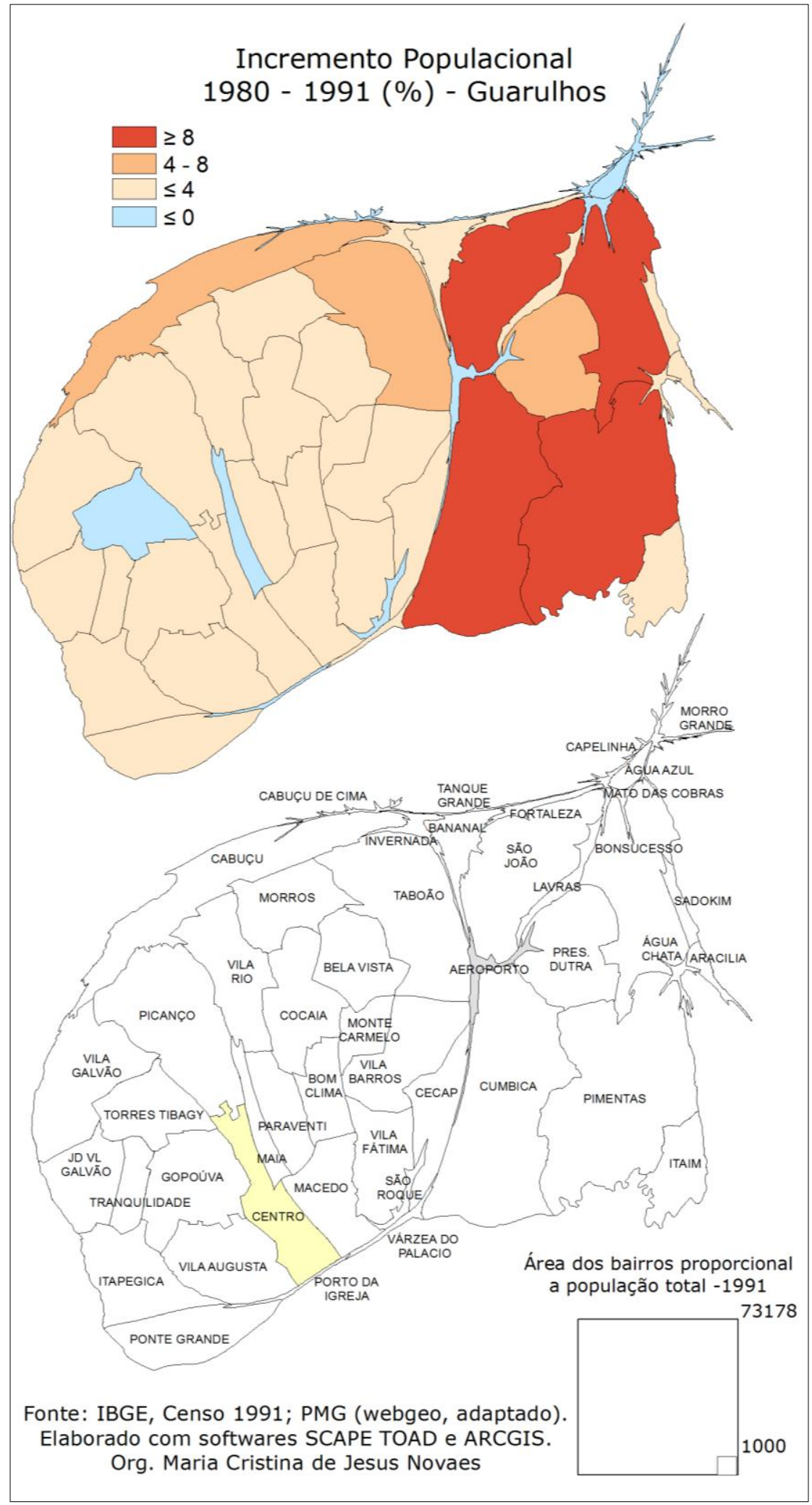

Figura 10 - Incremento Populacional - Guarulhos (1980 a 1991). 
Com índices entre 4 e $8 \%$, ficaram o Presidente Dutra e Cumbica, que teve o seu crescimento reduzido em relação ao período anterior, mas continuou detendo a segunda maior população do município, com 88.384 moradores. Além desses, apresentou o mesmo índice o conjunto de bairros posicionado na parte norte do adensamento urbano: Cabuçu (59.675 pessoas) e Taboão (66.037 pessoas), ambos desde a década passada, aos quais se agregaram a Vila Rio, Morros e Fortaleza, ver também Figuras 09 e 11.

No sentido contrário, é relevante a diminuição de moradores em alguns bairros, sobretudo, aqueles em que a ocupação remonta aos primórdios da urbanização do município e que, relativamente, apresentam melhor infraestrutura e maior quantidade de equipamentos coletivos. 0 mesmo ocorreu com o conjunto de bairros próximos à margem esquerda do Aeroporto. Parte dessa dinâmica atribui-se à refuncionalização dos objetos, em que a função residencial foi substituída pelas funções ligadas aos serviços e comércios, entre os bairros com destaque para o Centro.

Em 2010, no último censo, a população totalizou 1.221 .979 habitantes, após apresentar o menor índice de crescimento dos períodos analisados, que foi de $1,41 \%$, entre 2000 e 2010, resultando em 149.262 pessoas a mais no município. Na Figura 08, ao adotar-se como parâmetro o bairro do Aeroporto, observa-se que, ao comparar o conjunto de bairros da porção oeste com o conjunto de bairros da porção leste, percebe-se, na Figura 12, que em 2010 a desproporção entre eles já não era tão acentuada como em 1980.

Não se chegou a um equilíbrio por conta do crescimento elevado do grupo de bairros posicionados no centro-norte do adensamento urbano, formados pela Vila Rio, Morros, Taboão, Bananal, Invernada, com taxas de crescimento anual entre 4 e $8 \%$ e do Cabuçu, que se juntou aos bairros com índices superiores a $8 \%$. Este foi o caso do Pimentas, que atingiu 156.748 habitantes, e do Bonsucesso, com 93.666 pessoas.

Com relação aos bairros que perderam habitantes, ocorreram pequenas alterações. Ressaltam-se os bairros de Vila Augusta e Vila 


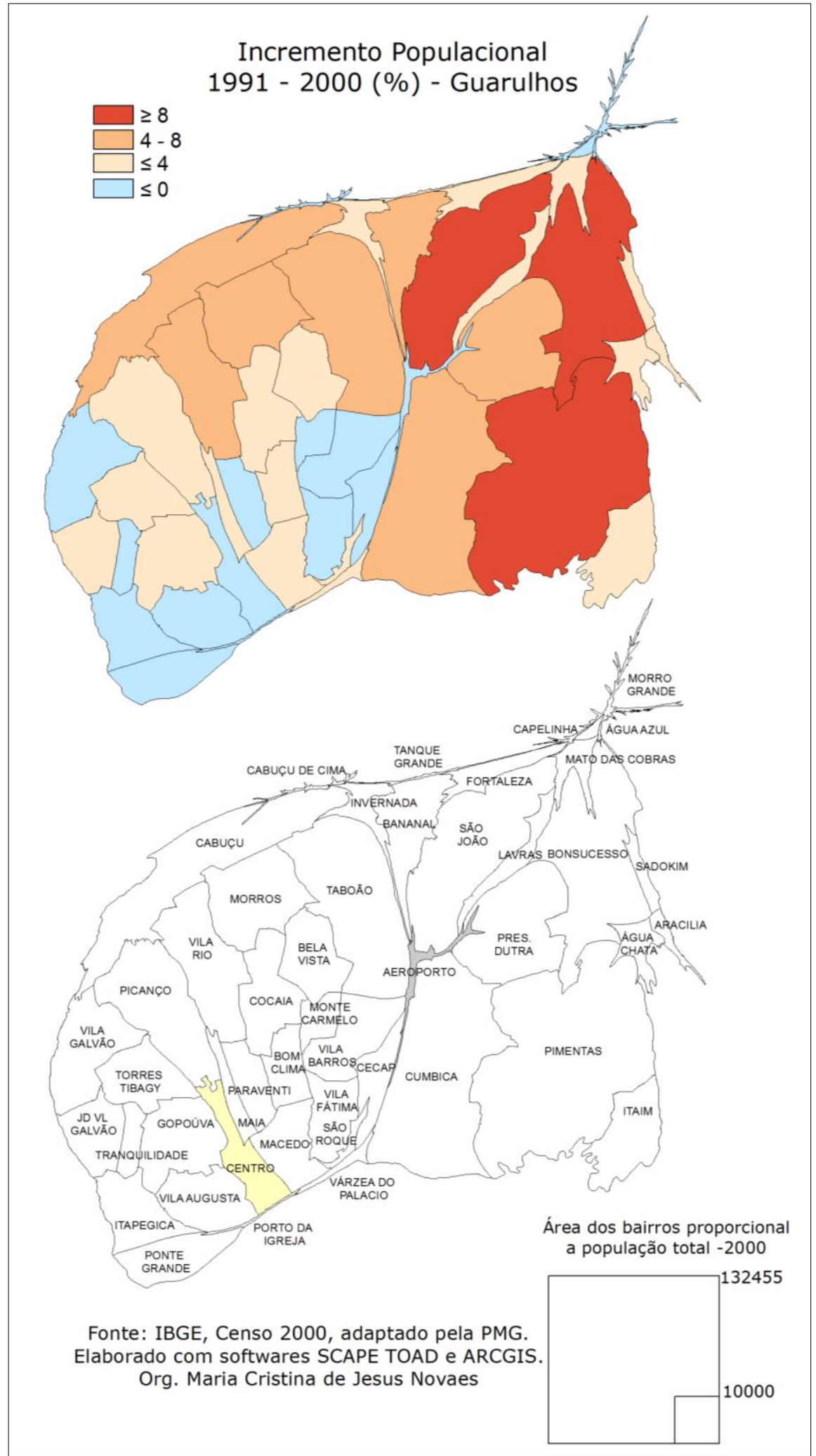

Figura 11 - Incremento Populacional - Guarulhos (1991 a 2000). 
Galvão, que deixaram de perder habitantes, sobretudo, pela instalação de edifícios residenciais. O município passa por um intenso processo de verticalização, principalmente depois de 2007, o que se discute no próximo capítulo. O mesmo processo atingiu o Centro que, mesmo assim, manteve incremento populacional negativo, mas como mencionado, resultante da refuncionalização dos objetos, incentivados, inclusive, pelo próprio processo de verticalização.

A figura 06 revela ainda, que, ao excluir o aeroporto, a evolução urbana à medida que avançava, ia deixando vários terrenos vazios por todo o município, incluindo as áreas centrais. De acordo com a PMG (2002) predominavam terrenos de $500 \mathrm{~m}^{2}$, porém havia outros maiores em todos os bairros. Ainda, segundo a Prefeitura, em 2000, de aproximadamente 300.000 imóveis registrados na área urbana, cerca de 57.000 estavam vagos, totalizando $43 \mathrm{Km}^{2}$. Se considerarmos a área ocupada do município, que é em torno de $212 \mathrm{Km}^{2}$, destes um pouco mais que $20 \%$ estão desocupados (PMG, 2011). Vale mencionar que pequena parte desses terrenos vazios foi destinada à construção de edifícios.

A partir de 1991, o aporte populacional guarulhense resultou, em sua grande maioria, do crescimento vegetativo, diferentemente das décadas precedentes em que o componente migratório era mais significativo. Segundo a Tabela 01, entre 1980 e 1991, a taxa anual de migração foi de 10,96\%, que subiu e chegou a 17,08\%, entre 1991 e 2000 e caiu, drasticamente, entre 2000 e 2010, quando foi de apenas $0,04 \%$.

Da forma como ocorreu a evolução urbana, grande aumento da área "ocupada", em curto intervalo de tempo, entremeada de vazios, pode-se afirmar que Guarulhos se caracteriza como uma cidade espraiada. Este conceito foi desenvolvido por Santos (1994a e 2009a) e tem como fundamento uma urbanização corporativa, em que há interdependência entre as categorias espaciais relevantes: tamanho urbano, modelo rodoviário, carência de infraestruturas, especulação fundiária e imobiliária, problemas de transporte, extroversão e periferização da população, 


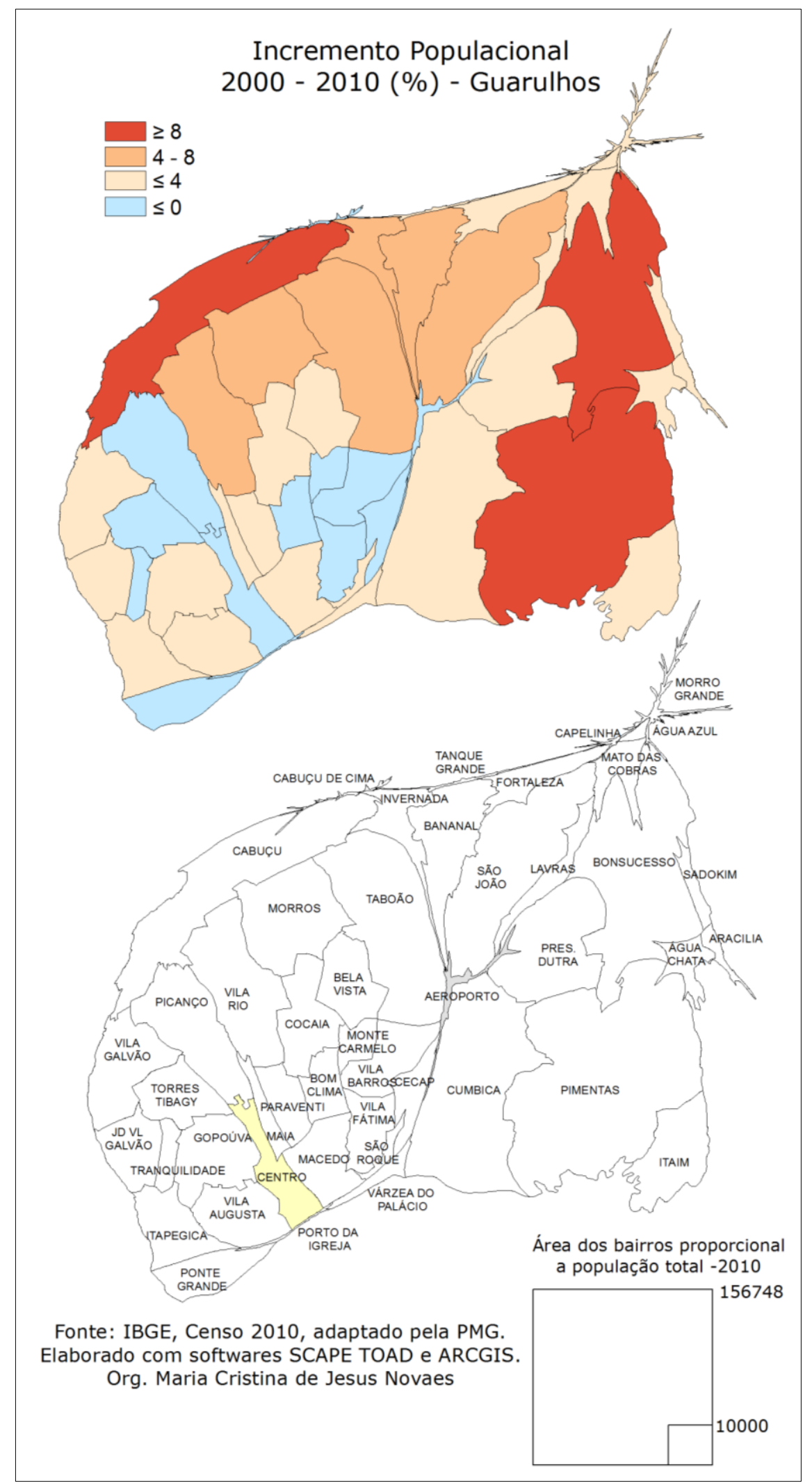

Figura 12 - Incremento Populacional - Guarulhos (2000 a 2010). 
gerando, graças às dimensões da pobreza e seu componente geográfico, um modelo específico de centro-periferia. Segundo o autor, essas categorias espaciais interagem com crescimento urbano. Esses conteúdos são retomados e aprofundados na discussão sobre a segregação.

Adotado pelos discursos voltados para atrair os investimentos econômicos, o adensamento populacional correlacionou-se às mudanças na vida material e imaterial. Essas transformações, um dos aspectos importantes do meio técnico-científico-informacional, ocorrem pelo grande desenvolvimento da produção material, que se modifica estruturalmente, assim como a circulação, a distribuição e o consumo. As formas de produção não material como saúde, educação, lazer, informação e esperanças, também se expandem pelo território (SANTOS, 1994b).

No gráfico 01, é mostrada a evolução do PIB guarulhense, observando-se que ele se manteve estagnado entre 1980 e 1990. Nesse período, o Brasil enfrentava uma crise econômica e transitava da Ditadura Militar para a abertura democrática, que resultou, a partir dos anos 90, na eleição de presidentes, os quais impuseram a Política neoliberal. Esta passou a acionar os objetos da produção material, assim como aqueles referentes aos serviços sociais. Entre as ações, destacam-se as adotadas pelo presidente Fernando Henrique Cardoso como a privatização das indústrias estatais, a reorganização da estrutura bancária no sentido de sua concentração (PROER), o estabelecimento da paridade da nova moeda (real) com o dólar, o incentivo a vinda de capital estrangeiro, a promoção do desemprego em grande escala e a introdução do assistencialismo como política de Estado. Para tal contou com a contribuição do Fundo Monetário Internacional e do Banco Mundial.

De acordo com Santos (1997), o neoliberalismo é o braço político da globalização mas, se por um lado os discursos que sustentam tal política defendem a menor interferência do Estado, ou seja, o Estado Mínimo, livre para a ação da iniciativa privada, por outro lado, não é o que se vê na prática. Como ressalta o autor 
Ao contrário do que se repete impunemente, o Estado continua forte e a prova disso é que nem as empresas transnacionais, nem as instituições supranacionais dispõem de força normativa para impor, sozinhas, dentro de cada território, sua vontade política ou econômica (SANTOS,2000, p.77).

Aliás, é o Estado, em todas as suas esferas, que viabiliza estruturalmente os sistemas de objetos necessários às ações hegemônicas, como se busca demonstrar a partir das analises aqui empreendidas, em que os custos para instalação dos sistemas de engenharia ocorrem de forma socializada, mas os benefícios mais expressivos são apropriados de forma privada e, cada vez mais, ultraminoritária.

Ao retomar o gráfico 1 , pode-se observar que, a partir de 1990, 0 PIB passa a aumentar e, em 2000, girava em torno de 13 bilhões de reais, e na primeira década do século XXI teve um crescimento expressivo, chegando, em 2009, a mais de 32 bilhões de reais e ao nono maior PIB brasileiro. Esse desempenho é justificado pela mudança do governo federal, em que Luís Inácio Lula da Silva passou a ser o presidente, entre 2003 e 2010. A política econômica praticamente manteve-se a mesma do antecessor, com algumas mudanças, como a suspensão das privatizações das indústrias, embora tenha instituído novas parcerias entre o público e o privado, como é o caso do PROUNI. Este criado em 2004, consiste em oferecer bolsas de estudo integrais e parciais, em instituições de educação superior privadas a estudantes brasileiros, sem diploma de nível superior. Também expandiu as políticas assistencialistas.

O crescimento econômico também foi favorecido pela retomada do crescimento externo, resultando, entre outros, na redução da taxa do desemprego, recuperação parcial do poder de compra dos salários, alta arrecadação de impostos, fluxo contínuo de capital externo e superávit comercial. 


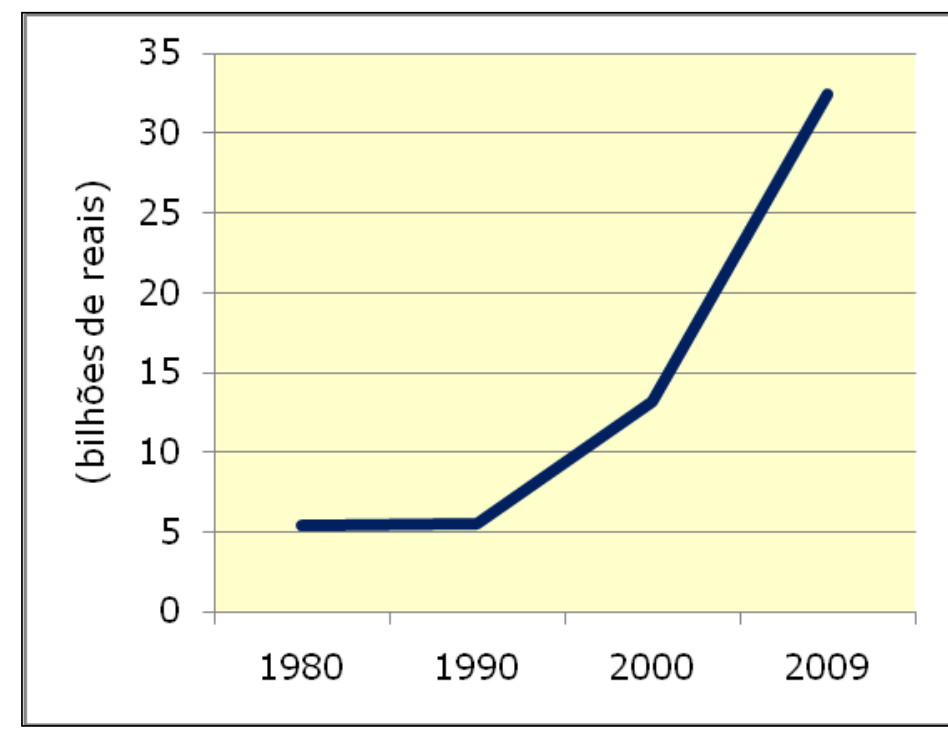

Gráfico 01 - PIB - 1980 a 2009 Guarulhos (IBGE -SEADE).

A chegada do aeroporto conjugou-se à reestruturação produtiva que, como destacaram Milton Santos (2009a) e Maria de Fátima I. Araújo (2001), se acelerou a partir dos anos 90, e a RMSP não deixou de ser a metrópole industrial, tornando-se, também

[...] a metrópole dos serviços, metrópole terciária, ou ainda melhor quaternária, o grande centro de decisões, a grande fábrica de ideias que se transformam em informações e mensagens, das quais uma parte considerável são ordens (SANTOS, 2009a, p.38).

Isso resultou na conversão da região, no final do século passado, em lócus das sedes de grandes empresas industriais, financeiras e prestadoras de serviço do país, transformando-se numa metrópole informacional, que se assenta sobre a metrópole industrial, não sendo, porém, a mesma metrópole (SANTOS, 1994b; ARAÚJO, 2001).

Como metrópole de um país subdesenvolvido industrializado, de acordo com Milton Santos (2009a), a RMSP combina traços de opulência, resultante da pujança da vida econômica e suas expressões materiais com o atraso das estruturas sociais e políticas.

Segundo Araujo (op.cit.), o que desconcentrou e reduziu na RMSP no período, foi o emprego, especialmente o industrial. No caso de Guarulhos, o gráfico 02 registra que os menores índices de contratações 
ocorreram entre 1995 e 2000; a partir de então, praticamente, só aumentaram as contratações, que, em 2010, chegaram a mais de 325.000 pessoas oficialmente contratadas.

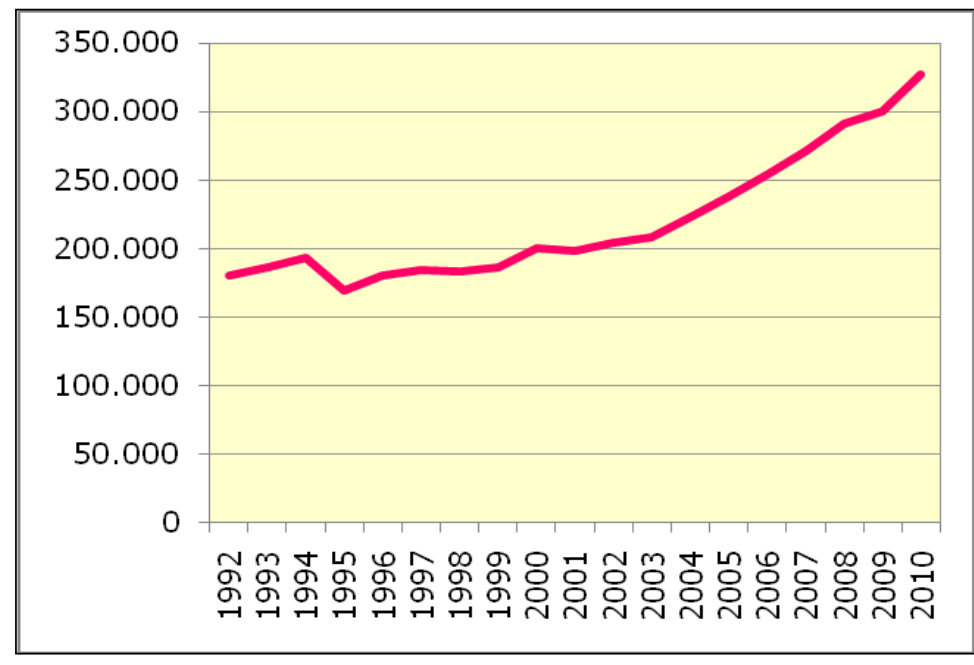

Gráfico 02 - Pessoas formalmente contratadas Guarulhos - 1991 a 2010 (SEADE).

Outro fenômeno importante do momento histórico, assinalados por Santos (1994b, 2009b) e Silveira (2006b) é que nas regiões metropolitanas, boa parte da população está ocupada em atividades de serviços, mas o comércio não para de crescer e é também um importante contratador de mão-de-obra. Esse fenômeno resulta de uma economia pontual de atividades modernas coexistindo com uma enorme economia pobre, orientada ao comércio e aos serviços mais banais nessas grandes cidades, que é o que Milton Santos (2009b) denomina de involução urbana, concerne no crescimento das atividades modernas e da pobreza, identificada pela queda no rendimento salarial médio e na expansão de empregos mal remunerados, com a correspondente piora nas condições de vida.

Nesse sentido, o autor aponta para a economia dois grandes circuitos, o circuito superior e o circuito inferior (SANTOS, 2003), que é excluído das estatísticas oficiais. Marina Montenegro (2006), em sua dissertação de mestrado, discute as características de tais conceitos para o atual período da globalização. Segundo a autora, o circuito superior 
resulta das modernizações que atingem o território, alimentados pela aceleração contemporânea global, e o circuito inferior tem o tempo e as formas do lugar em que está inserido. Ele compreende as formas de fabricação não capital intensivo, os serviços não modernos fornecidos a varejo e o comércio de pequena dimensão, voltados, sobretudo, ao consumo dos mais pobres. É importante lembrar que o Circuito inferior atinge também a produção fabril.

Em Guarulhos, o Circuito Inferior da economia, necessita de um importante estudo, diante da sua abrangência em intensidade e extensão pelo território. Como se correlaciona ao território guarulhense a formação de lugares resultantes de loteamentos totalmente desprovidos de recursos básicos, sem nenhuma característica de urbanização (GAMA, 2009), as pessoas que passaram a residir nesses locais tiveram de forjar os meios para prover suas necessidades elementares, que incluíam o abastecimento das atividades de serviços e comércios. Vale lembrar que essa é uma entre outras formas com que se foram expandindo as atividades ligadas ao Circuito Inferior. Outra característica importante é que, muitas vezes, certos espaços com função residencial conjugam funções vinculadas ao sistema produtivo, que é um complicador na sua identificação e mensuração.

Se durante um momento da sua existência, muitos bairros não contavam com sistemas de objetos modernos ligados aos serviços e comércios, no presente é diferente. Eles vão ajudando a compor os objetos das centralidades secundárias que se vêm constituindo na cidade, graças também às políticas públicas, implementadas no município, que se associam ao fortalecimento do núcleo central. Essas centralidades secundárias referem-se aos populosos bairros Pimentas, São João, Taboão, Presidente Dutra, Cumbica e Bonsucesso, cujo conteúdo será abordado com a segregação no próximo capítulo.

Com relação à produção fabril, que tem um papel importante na economia guarulhense, nota-se que passou a compartilhar com o setor terciário as principais funções produtivas e, em menor proporção, com a 
construção civil. A produção agropecuária do município é muita reduzida, empregando apenas $0,04 \%$ das 327.525 pessoas que estavam formalmente contratadas em 2010.

De acordo com a classificação da Fundação Seade sobre o perfil do município até 2005, Guarulhos enquadrava-se na tipologia industrial, devido ao peso relativo que tinha na composição do PIB (Produto Interno Bruto). A partir de 2006, passou a ser classificado como "multissetorial". Essas mudanças estão presentes no gráfico 03, construído com base nos dados do SEADE, que representa a proporção de estabelecimentos. Entre 1991 e 2010, ao comparar as indústrias com as outras funções produtivas, observa-se que elas vêm diminuindo desde 1995, embora, a partir do mesmo ano, em números absolutos, tenham aumentado os estabelecimentos industriais, que saltaram de 1.760 em 1995 para 2.675 em 2010.

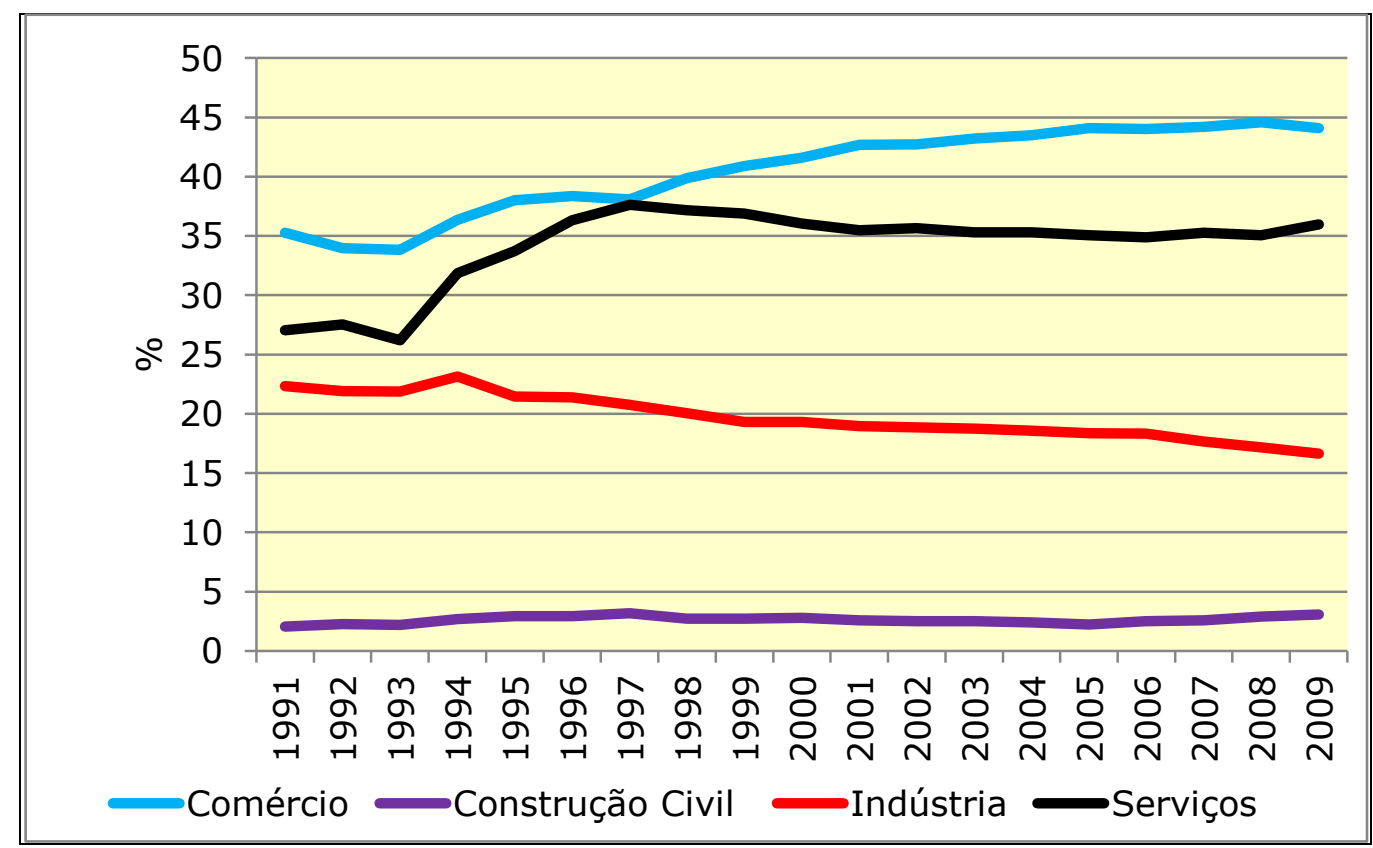

Gráfico 03 - Proporção de Estabelecimentos do Total - Guarulhos (SEADE).

Com relação à geração de emprego, o gráfico 04 mostra a participação das funções produtivas, conforme os vínculos empregatícios. Identifica-se que, em 1991, a indústria era o principal empregador do município, responsável por mais da metade dos vínculos; a partir de 
então, esse número foi se reduzindo, sobretudo na década de 90 do século passado e, desde 2008, deixou de ser o setor que mais empregava no município, posição que foi ocupada pela área de serviços. Mesmo com essa queda, em 2010, a indústria correspondeu a mais de $37 \%$ dos vínculos empregatícios e ao maior rendimento médio do município (RS $2.259,00)$, mostrado no Gráfico 05. Parte dessa queda na participação das indústrias parece estar associada à modernização da produção, assim como as indústrias passaram a terceirizar algumas funções, visando baratear os custos com a mão-de-obra.

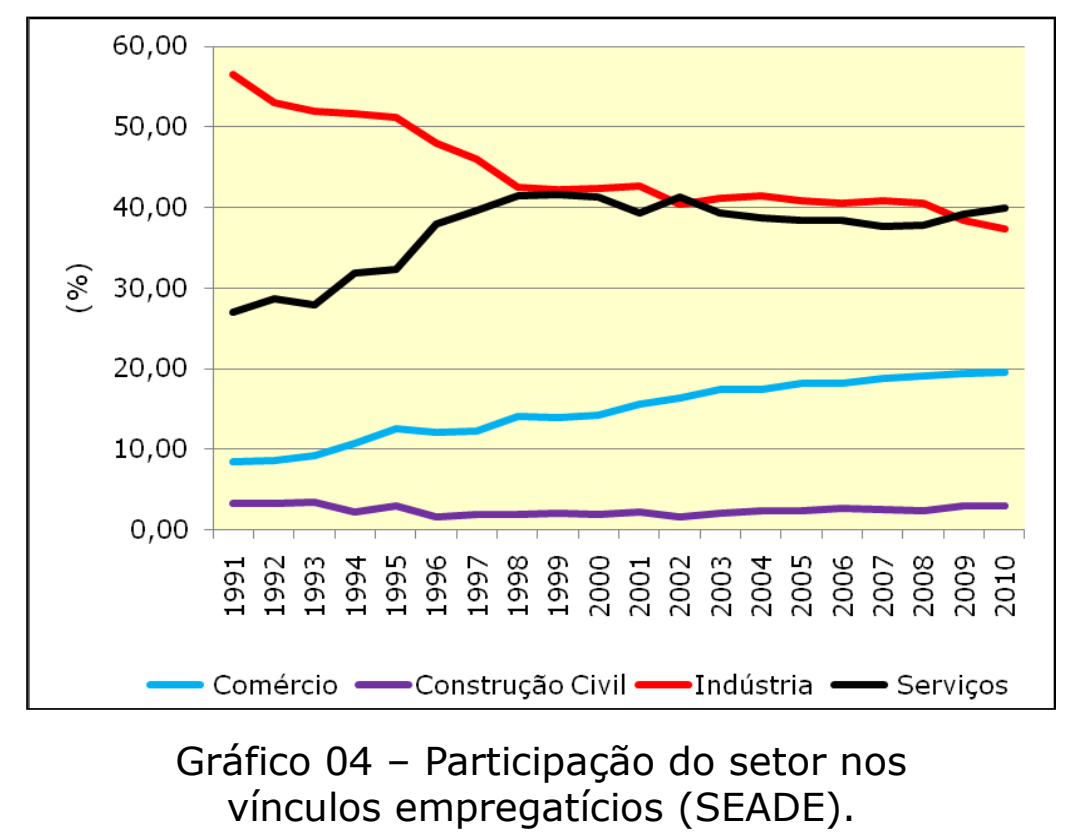

O parque industrial guarulhense constitui um dos maiores do país (oitavo) e o segundo maior do Estado de São Paulo (PMG, s/d). As principais áreas industriais correspondem aos bairros de Bonsucesso (próximo à Dutra), Itapegica (contíguo à Dutra e à Rodovia Fernão Dias), Taboão (vizinho ao Aeroporto) e Cumbica (contíguo às Rodovias Dutra e Ayrton Senna). Este se constitui no principal deles e reúne mais de 700 empresas, (área com maior concentração contínua, que se observa na Figura 13), contando, também, com grande número de transportadoras e empresas de logística, o que permite o escoamento dos produtos fabricados pelas indústrias locais (PMG, 2002). Ressalta-se a correlação 
entre a localização do sistema produtivo e do sistema de circulação, que se associa à afirmação de Flávio Villaça (1998), segundo à qual as indústrias exploram a acessibilidade como critério para a sua localização.

Das mais de 2.500 empresas, cerca de 2.000 delas são de pequeno e médio porte ( $P M G, s / d$ ), desses números, infere-se a coexistência entre indústrias modernas e indústrias menos modernas, que se associam à discutida involução urbana. Assim, há no mesmo tecido urbano, segundo Milton Santos (2009b), a convivência entre unidades distintas quanto ao tamanho, grau de capitalização, organização e tecnologia, que contam com a diversidade do consumo local formado por diferentes classes sociais.

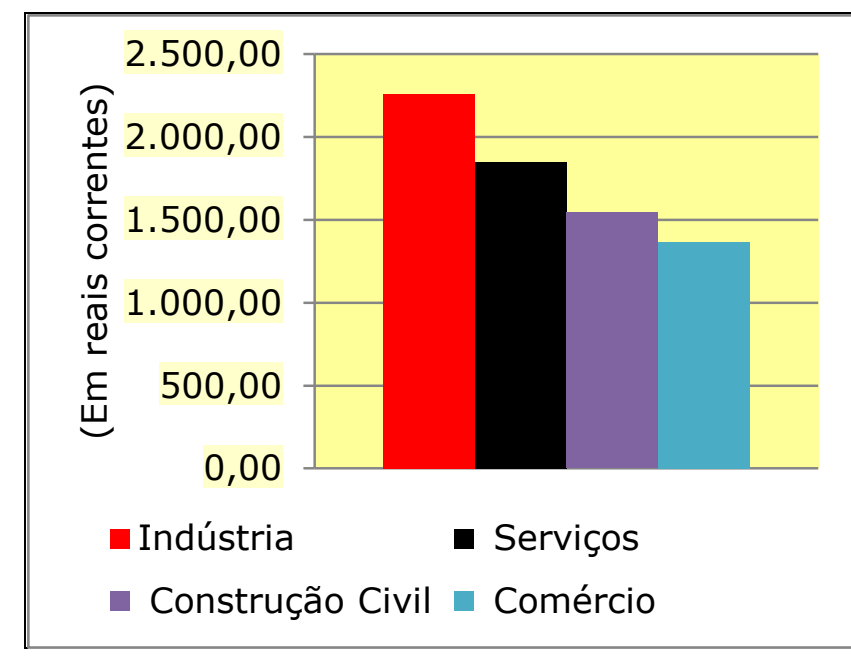

Gráfico 05 - Rendimento médio dos vínculos empregatícios Guarulhos - 2010 (SEADE).

O valor adicionado fiscal, proveniente do setor industrial foi de $R \$$ 13,5 bilhões, aproximadamente, em 2009. Entre as indústrias se sobressai a participação das farmacêuticas com $20,8 \%$ desse valor, seguida pelas de material de transporte (montadoras e autopeças) com 12,3\%, das empresas de produtos de metal que detêm $9,9 \%$, das de máquinas e equipamentos com $9,1 \%$, dos produtos químicos com $8,0 \%$ e de metalurgia básica com 5,5\%. 


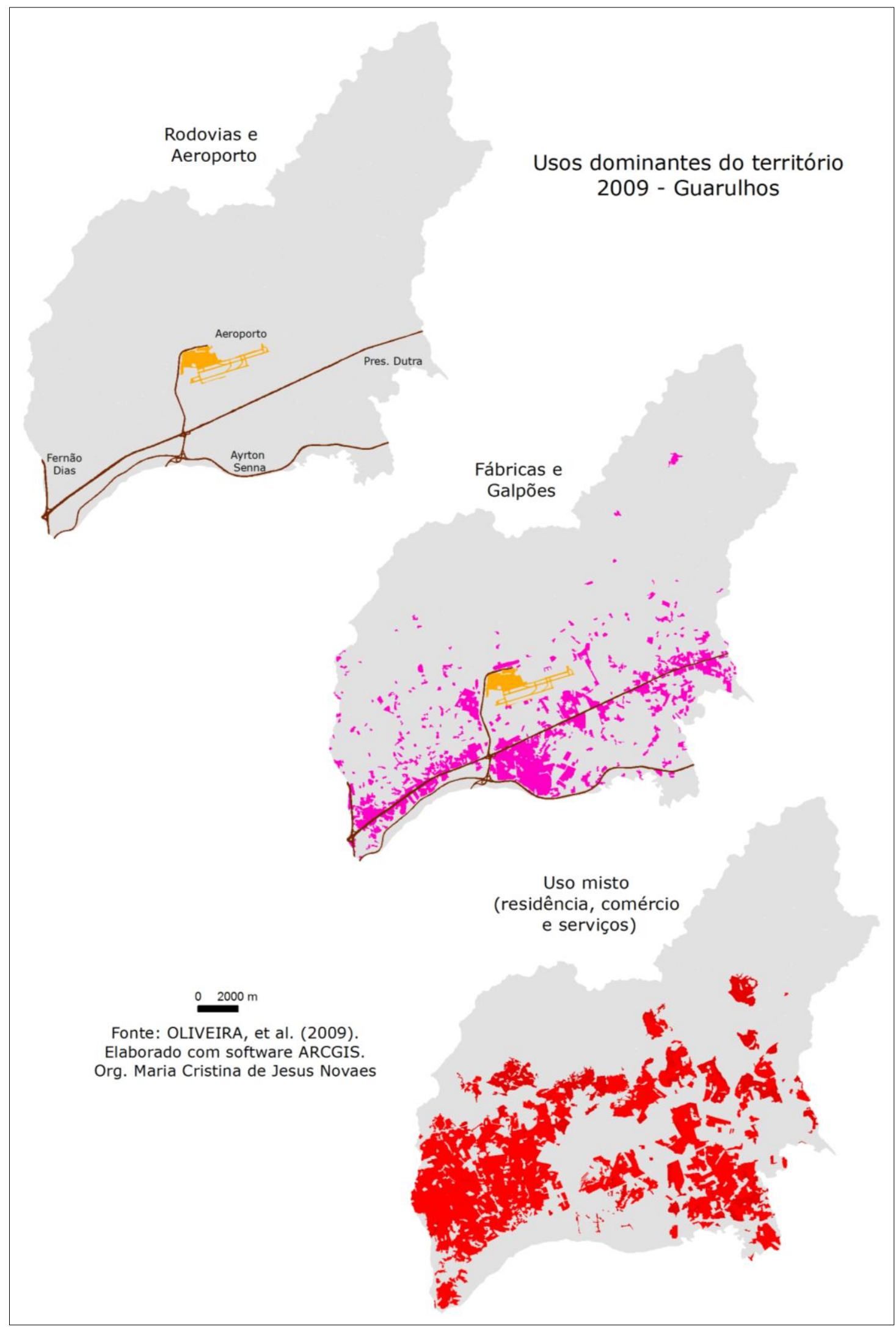

Figura 13 - Usos dominantes do território - Guarulhos. 
O Grupo Olho Vivo (2008), que faz parte da imprensa local, publicou, em 2008, em sua revista "Quem é Quem", a classificação das empresas conforme o faturamento líquido em 2007. Na tabela 02, foram reunidas as 10 primeiras colocadas que, juntas, faturaram cerca de $R \$ 7,8$ bilhões, das quais oito são do setor industrial e seis delas são de capital estrangeiro.

A produtividade associada as funções ligadas ao serviço, principalmente, e ao comércio ganharam relevância no município. As atividades terciárias corresponderam a $67,66 \%$ do total do valor adicionado e significaram mais de R\$ 18 bilhões em 2009 (SEADE). Os objetos ligados as atividades terciárias estão distribuídas por todo 0 território, por isso aparece na Figura 13, com os usos mistos.

Ao ater-se especificamente ao comércio, o Gráfico 04 indica que, em relação aos demais setores compreendidos por ele, os vínculos empregatícios que mais cresceram, sem interrupção, foram aqueles ligados ao comércio. Em 1991, eram menos de 10\% dos empregos formais e em 2010 quase atingiram a taxa de 20\%; o rendimento salarial, contudo, é o mais baixo do município - R\$1.366,59 - como se observa no gráfico 05 .

A função comercial subdivide-se em comércio atacadista, que correspondeu a pouco mais que um terço do valor adicionado, e comércio varejista, em que se sobressai a expansão das empresas mundiais, principalmente neste século. Entre elas, há as grandes redes de hipermercados, como os franceses Carrefour e parte majoritária do Extra, o norte-americano Walmart e os brasileiros Sonda e Roldão; assim como os de materiais de construção, que são a Telha Norte, que integra a rede varejista francesa Saint-Gobain, e as brasileiras Dicico e a C\&C Casa e Construção. Existem, também, os shopping centers, que reúnem grandes 
Tabela 02 - As dez maiores empresas, segundo o faturamento de 2007.

\begin{tabular}{|c|c|c|c|c|c|}
\hline $\begin{array}{c}\text { Classifi } \\
\text { cação }\end{array}$ & Empresa & Setor & Subsetor & $\begin{array}{l}\text { Receita } \\
\text { líquida } \\
\text { (Valores } \\
\text { em R\$ } \\
1.000 \text { ) }\end{array}$ & $\begin{array}{c}\text { Capital/ } \\
\text { Fundação } \\
\text { em } \\
\text { Guarulhos }\end{array}$ \\
\hline 1 & $\begin{array}{c}\text { LABORATÓRIOS } \\
\text { PFIZER LTDA }\end{array}$ & Indústria & $\begin{array}{c}\text { Produtos } \\
\text { farmacêuticos } \\
\text { e veterinários }\end{array}$ & 1.472 .000 & $\begin{array}{c}\text { Americano } \\
1960\end{array}$ \\
\hline 2 & ABB LTDA & Indústria & $\begin{array}{c}\text { Serviços } \\
\text { elétricos e } \\
\text { equipamentos }\end{array}$ & 1.394 .000 & $\begin{array}{l}\text { Suíço } \\
1954\end{array}$ \\
\hline 3 & $\begin{array}{c}\text { CUMMINS } \\
\text { BRASIL LTDA }\end{array}$ & Indústria & Autopeças & 1.328 .250 & $\begin{array}{c}\text { Americano } \\
1974\end{array}$ \\
\hline 4 & $\begin{array}{c}\text { VISTEON } \\
\text { SISTEMAS } \\
\text { AUTOMOTIVOS }\end{array}$ & Indústria & Autopeças & 1.096 .000 & $\begin{array}{c}\text { Americano } \\
1972\end{array}$ \\
\hline 5 & $\begin{array}{c}\text { ACHÉ } \\
\text { LABORATÓRIOS } \\
\text { FARMACÊUTICOS } \\
\text { LTDA. }\end{array}$ & Indústria & $\begin{array}{c}\text { Produtos } \\
\text { farmacêuticos } \\
\text { e veterinários }\end{array}$ & 954.233 & $\begin{array}{c}\text { Brasileiro } \\
1966\end{array}$ \\
\hline 6 & $\begin{array}{c}\text { RIO NEGRO } \\
\text { COMÉRCIO E } \\
\text { INDÚSTRIA DE } \\
\text { AÇO S/A }\end{array}$ & Indústria & $\begin{array}{c}\text { Produtos } \\
\text { metalúrgicos }\end{array}$ & 733.973 & $\begin{array}{c}\text { Brasileiro/ } \\
\text { Japonês } \\
1973\end{array}$ \\
\hline 7 & $\begin{array}{c}\text { FELÍCIO } \\
\text { VIGORITO \& } \\
\text { FILHOS LTDA. }\end{array}$ & Comércio & $\begin{array}{l}\text { Revenda de } \\
\text { automóveis }\end{array}$ & 536.968 & $\begin{array}{c}\text { Brasileiro } \\
1966\end{array}$ \\
\hline 8 & FACCHINI S/A & Indústria & Carrocerias & 481.912 & $\begin{array}{c}\text { Brasileiro } \\
1950\end{array}$ \\
\hline 9 & CLAREX S/A & Comércio & $\begin{array}{c}\text { Empresas } \\
\text { Com. } \\
\text { Exportadoras }\end{array}$ & 416.970 & $\begin{array}{c}\text { Brasileiro } \\
1997\end{array}$ \\
\hline 10 & $\begin{array}{c}\text { BRENNTAG } \\
\text { QUÍMICA BRASIL } \\
\text { LTDA. }\end{array}$ & Indústria & $\begin{array}{l}\text { Diversos } \\
\text { produtos } \\
\text { químicos }\end{array}$ & 373.000 & $\begin{array}{c}\text { Alemão } \\
1996\end{array}$ \\
\hline
\end{tabular}

Fonte: Quem é Quem na Economia de Guarulhos (2008) 
empresas de distribuição de produtos e serviços, como o Internacional (inaugurado em 1998, com 320 lojas), um dos maiores da RMSP, o de Bonsucesso (inaugurado em 2006, que abriga 140 lojas) segundo maior do município, o Poli Shopping (inaugurado em 1989, com 61 lojas) e o Aeroshopping.

Considerando os dados do setor de serviços, no gráfico 03, identifica-se que a proporção desses estabelecimentos aumentou entre 1991 e 1997, com exceção do ano de 1993, quando houve um declínio. Após esse período, foram pequenas as variações, sobretudo as negativas, que se deveram ao crescimento dos objetos ligados ao comércio. Em 2010, os estabelecimentos de serviços eram 6.049 , que correspondiam a $36 \%$ do total dos presentes no município.

Com relação à geração de empregos, nota-se no gráfico 04 , que as funções ligadas aos serviços cresceram mais na última década do século passado, do que na primeira desse século, em que se manteve praticamente estabilizado. Desde 2008, é o setor que mais emprega no município, responsável por cerca de $40 \%$ dos vínculos empregatícios, mas o rendimento médio salarial é inferior ao da indústria, e foi de $R \$$ 1.850,02, em 2010, segundo o Gráfico 05.

O crescimento do setor de serviços, como mencionado, na última década é atribuído também ao processo de terceirização, promovido pela indústria local que, cada vez mais, terceiriza serviços como armazenagem, vendas, entregas, manutenção, segundo Pilotto et al.(2012), que precariza as condições de trabalho e diminui o rendimento salarial, sendo mais um fator que se associa à involução urbana.

Entre objetos que se expandiram pelo território ligados aos serviços, estão as instituições bancárias que ampliaram o número de agências, de postos de atendimentos e caixas eletrônicos. No gráfico 06, percebe-se que em 1988 havia menos de 60 agências, as quais, no final do século, chegaram a quase 80 , e na década seguinte viu esse ritmo acelerar, quando, em 2010, atingiu 125 agências. 


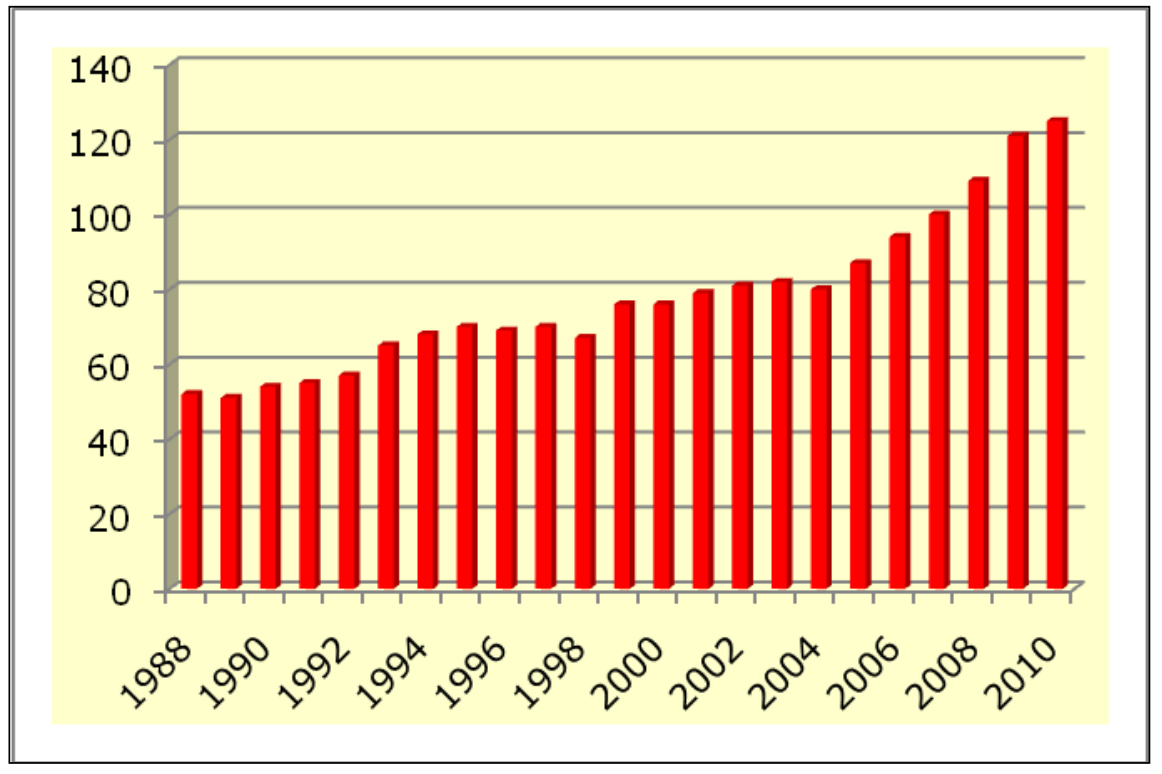

Gráfico 06 - Número de agências bancárias

Fonte:SEADE

O Grupo Olho Vivo realizou levantamento sobre as instituições bancárias instaladas em Guarulhos em 2008, que foram reunidas na Tabela 03. De acordo com ela, os bancos privados Itaú e Bradesco, considerando as fusões que realizaram após a data do levantamento, eram os que detinham o maior número, respectivamente, 29 e 19 agências. Entre os bancos estatais, a Caixa Econômica Federal tinha 11 agências, número inferior ao de agências do Banco do Brasil, que chegou a 17 agências, considerando a incorporação da Nossa Caixa. As áreas de maior concentração de agências bancárias estão nos bairros do Centro, Cumbica, Vila Galvão e Aeroporto, mostrando a correlação com a concentração das demais funções produtivas.

Outro subsistema de objetos, ligado ao setor terciário, que teve grande expansão pelo território foi o de telecomunicações, sobretudo a partir de 2010. Segundo Santos (1994b), constitui um outro aspecto do meio técnico-científico-informacional, o desenvolvimento da configuração territorial associado ao desenvolvimento exponencial do sistema de transportes e do sistema de telecomunicações.

Em 2002, segundo dados da Prefeitura, os serviços oferecidos referiam-se, principalmente, à rede de telefonia fixa, à internet discada e, 
pontualmente, à TV a cabo, que eram realizados pela Telefônica, Vésper e Embratel. Esta última atuava nos serviços de telefonia de forma bastante limitada.

Tabela $03-\mathrm{N}^{0}$ de agências por instituição bancária

\begin{tabular}{|l|c|}
\hline Banco & No agências \\
\hline Banco Itaú S.A. & 29 \\
\hline Banco Bradesco S.A & 19 \\
\hline Banco do Brasil S.A & 17 \\
\hline Caixa Econômica Federal & 11 \\
\hline Banco Santander S.A. & 18 \\
\hline HSBC Bank Brasil S.A & 3 \\
\hline Banco Safra & 2 \\
\hline Banco Citibank S.A. & 1 \\
\hline Banco Fibra S.A. & 1 \\
\hline Banco Mercantil do Brasil S.A & 1 \\
\hline Banco Industrial e Comercial S.A> & 1 \\
\hline Total & 103 \\
\hline
\end{tabular}

Fonte: Quem é Quem na Economia de Guarulhos (2008)

Atualmente, as empresas de telefonia vêm passando por diferentes fusões entre as diversas operadoras existentes. Dessa forma, continuou atuando em Guarulhos a TELEFÔNICA que, atualmente, passou a ser denominada VIVO; a EMBRATEL, que passou a ser a CLARO; e, além dessas, agregaram-se a NET e a GVT. Essas empresas disputam acirradamente a venda de serviços de telefonia fixa, internet banda larga e TV por assinatura. Tudo isso resultou na diversificação dos tipos de produtos oferecidos e na expansão pelo território guarulhense.

A presença do aeroporto atrai uma série de serviços ligados à área de transporte e logística, hotelaria e eventos. Sua presença, no período de instalação trouxe certo incômodo; atualmente, no entanto, é um dos principais atrativos do território guarulhense, utilizado pelos representantes do poder público e empresariado, assim com os demais objetos do sistema de circulação (representados na Figura 09), a inserção 
da cidade na RMSP e sua proximidade com a capital paulista. Esses fatores exercem influência, atraindo para a cidade diferentes objetos produtivos, além de incentivo a aquisição de imóveis para fins residenciais em Guarulhos.

Em 2010, o Aeroporto de Cumbica totalizou o embarque e o desembarque de aproximadamente 285 milhões de pessoas pelos terminais de passageiros. São 46 empresas aéreas nacionais e internacionais, regulares, cargueiras e charters que utilizam 286 balcões de check-in. De Guarulhos, partem e chegam vôos procedentes e com destinos a 27 países e 153 cidades nacionais e estrangeiras. Para atender os usuários do aeroporto são 198 pontos comerciais presentes nos terminais de passageiros (INFRAERO, 2011).

Segundo a Infraero, o mercado de trabalho formado pelo sistema aeroportuário é de cerca de 1.700 empresas prestadoras de serviços, que empregam 28,2 mil profissionais, sendo, praticamente, a metade desse número, moradores de Guarulhos.

Nesse ano de 2012, o Aeroporto que era administrado pelo Infraero, autarquia federal, através de leilão passou a ser uma concessão da Invepar, consórcio que o arrematou. Esse consórcio é formado pela construtora baiana OAS, os fundos de pensão Previ, dos funcionários do Banco do Brasil, o Petros, dos funcionários da Petrobras, e o Funcef, dos servidores da Caixa Econômica e pela sul-africana ACSA. Segundo a Invepar, seu foco inicial é modernizar os estabelecimentos comerciais e os estacionamentos, juntos ao sistema aeroportuário que, segundo ela, opera com a produtividade muito aquém, se comparado a outros aeroportos internacionais.

O Consórcio pretende investir também no setor hoteleiro, que teve uma grande expansão pelo território nos últimos anos.

Hoje há hotéis ligados às redes mundiais como Accor, Meliá, Marriott, Monaco, Bristol Caesar Park, entre outros. Segundo a PMG (s/d), em 2002 eram 500 vagas de apartamentos nos hotéis existentes, que em 
2008 chegaram a 1.880 unidades. Atualmente, o município tem 23 hotéis em operação, que recebem por mês, aproximadamente 60 mil hóspedes.

Por fim, entre as funções produtivas discutidas, há aquelas que dizem respeito à construção civil. Em 1993, correspondia a 3,44\% dos vínculos empregatícios, alternando, desde então, pequenas quedas e subidas e atingindo o menor índice em $2002(1,67)$, quando voltou a subir e chegou a 3,05\% em 2010, em que o rendimento médio foi de $R \$$ $1.545,88$, visto no Gráfico 05 , que superou a média do comércio. O desempenho desse setor associa-se, também, ao comentado processo de verticalização.

Para o avanço do meio técnico-científico-informacional pelo território foi necessária a expansão dos serviços essenciais como a água e ligações elétricas residenciais, visto que eram extremamente precários.

Como explicado por Santos e Silveira (2001) a mudança do padrão de circulação no território, com as novas atividades econômicas (ligadas à industrialização e a formação de um setor urbano de serviços importantes) provocou a aceleração dos ritmos de vida e uma necessidade de maior fluidez na movimentação de pessoas e mercadorias, com o expressivo crescimento dos fluxos dos sistemas de movimento rodoviário e aeroviário no período posterior a Segunda Guerra Mundial.

Nesse sentido, verifica-se que o que vem sendo planejado ou está em execução no município, prioriza o sistema de circulação que, junto com os dados sobre as formas de produção não material do município, compõe o conteúdo sobre a segregação socioespacial de Guarulhos. 


\subsection{Segregação socioespacial em Guarulhos}

Para o atual momento histórico podem ser distinguidos três conceitos de segregação dentre os apresentados, e que estão presentes na cidade de Guarulhos.

O mais conhecido refere-se ao padrão de segregação centro e periferia, ao qual se vêm sobrepondo subespaços que recorrem, entre outros, a diferentes meios arquitetônicos e tecnológicos para evitar a socialização com os demais subespaços do entorno, que Caldeira (2000) nomeia "enclaves fortificados". O terceiro, também coexistindo com os demais, corresponde às desigualdades advindas com a disseminação do meio técnico-científico-informacional pelo território.

O modelo de segregação baseado no isolamento de um subespaço em relação aos demais tem se propagado pelo território de Guarulhos, por diferentes bairros, que contemplam perfis de renda distintos, como ressaltaram Lévy e Lussault (2003). Tal tipo não é o foco de estudo da presente dissertação, diferentemente dos outros dois que aqui se discutem.

Ao retomar o estudo sobre a formação territorial do município de Guarulhos, depreende-se que sua ocupação foi ocorrendo num contexto de periferização da RMSP. Como elucidaram Kowarick (1979), Santos (2009a) e Caldeira (2000), contudo, à medida que se expandia o adensamento urbano, os municípios que integram a RMSP iam constituindo a sua própria periferia. Nesse sentido, Guarulhos apresenta, no interior de sua configuração territorial, desigualdades que este trabalho se propõe identificar, a partir dos parâmetros em discussão.

Villaça $(1998,2003)$ considera a existência de segregação, quando há a concentração significativa de uma classe ou camada social em uma região ou conjunto de bairros, em relação aos demais. Assim, para RMSP apontou o quadrante sudoeste, como aquele que apresenta a maior concentração de bairros de classe média e acima da média. 
Ao comparar a proporção de domicílios, de acordo com as classes de rendimento, exposto na tabela 04, percebe-se que, em Guarulhos, o número entre 10 e 20 salários mínimos é de $5,76 \%$, quando no município de São Paulo é de 10,69\%. Na faixa acima de 20 salários mínimos, Guarulhos tem apenas $1,41 \%$ dos domicílios que, em São Paulo, correspondem a 6,33\%. A pequena proporção de domicílios de Guarulhos nas duas maiores faixas de rendimento reflete o contexto em que ocorreu o adensamento populacional no município. Outro diferencial é que aqueles domicílios constituem pequenas manchas no interior de alguns bairros. Assim, o principal critério adotado por Villaça de maiores faixas de rendimento, foi considerado insuficiente para Guarulhos. Vale lembrar que, em seus estudos, o autor correlaciona outros dados sociais para reafirmar o quadrante sudoeste como área privilegiada na RMSP.

Tabela 04 - Domicílios particulares permanentes - classes de rendimento mensal (\%)

\begin{tabular}{|l|c|c|c|c|c|c|c|c|}
\hline $\begin{array}{l}\text { Salário } \\
\text { mínimo }\end{array}$ & $\begin{array}{c}\text { Até } \\
1 / 2\end{array}$ & $\begin{array}{c}\text { Mais de } \\
1 / 2 \text { a } 1\end{array}$ & $\begin{array}{c}\text { Mais de } \\
1 \text { a } 2\end{array}$ & $\begin{array}{c}\text { Mais de } \\
2 \text { a } 5\end{array}$ & $\begin{array}{c}\text { Mais de } \\
5 \text { a } 10\end{array}$ & $\begin{array}{c}\text { Mais de } \\
10 \text { a } 20\end{array}$ & $\begin{array}{c}\text { Mais de } \\
20\end{array}$ & $\begin{array}{c}\text { Sem } \\
\text { rendimen } \\
\text { to }\end{array}$ \\
\hline Guarulhos & 1,35 & 7,81 & 21,85 & 38,23 & 17,75 & 5,76 & 1,41 & 5,85 \\
\hline São Paulo & 0,53 & 6,3 & 16,48 & 33,96 & 20,04 & 10,69 & 6,33 & 5,66 \\
\hline
\end{tabular}

Fonte: IBGE, Censo 2010.

Pensando nas desigualdades territoriais que, como mostrou Santos (1993), nas cidades brasileiras tornam as pessoas ainda mais pobres, às classes de rendimento agregam-se a questão da acessibilidade aos bens e serviços públicos essenciais. Nesse sentido, para Santos (op.cit.), os direitos inalienáveis do homem são, entre outros, a educação, a saúde, a moradia e o lazer, que, na presente dissertação, foram estudados com base nos principais equipamentos e indicadores a eles relacionados para identificação dos bairros, os quais, comparativamente, são segregados em Guarulhos. Para completar a identificação de tal tipo de segregação no interior da cidade, discutem-se as desigualdades associadas à instalação do meio técnico-científico-informacional. 
Sobre discussão desenvolvida a partir de Lévy e Lussault (2003), na qual destacam a redundância que advém da combinação do termo sócio e segregação, decidiu-se pela manutenção do termo, em razão de os parâmetros sociais operacionalizarem o estudo sobre segregação, mesmo reconhecendo que o espaço é uma instância, e como tal é composto pela instância social.

A partir desses critérios são discutidas a questão da saúde, educação, moradia e cultura/lazer e meio técnico-científico-informacional. 


\subsubsection{Saúde}

A partir de 1988, foi criado no Brasil o Sistema Único de Saúde (SUS) pelo Governo Federal, que tem como princípio a saúde como direito do cidadão e dever do Estado, buscando prover atenção abrangente e universal, preventiva e curativa, por meio da gestão e prestação descentralizadas de serviços de saúde, promovendo a participação da comunidade em todos os níveis de Governo. O contexto político e econômico em que foi instituído era regido pela Política neoliberal, cujo ideário é contrário as ações do financiamento público de sistemas de saúde; entretanto, as lutas, que integravam o processo de redemocratização do país, organizadas por distintos setores da população, colaboraram para a estruturação do sistema de saúde (PAIM et al., 2011).

Segundo Paim et al (op.cit), nos últimos 20 anos, entre os avanços obtidos pelo Sistema, houve a expansão do acesso à atenção básica e de emergência, cobertura universal para a vacinação e assistência pré-natal e investimentos na expansão dos recursos humanos e de tecnologia. Completando esse entendimento, Mariana Vercesi Albuquerque (2006) mostra que a modernização do uso do território pela saúde, enquanto norma, chegou a todos os lugares do Brasil, ou seja, os brasileiros têm o direito à saúde e o SUS é o sistema nacional que garante esse direito a todos os cidadãos. Mas a modernização do uso do território, enquanto direito efetivo, não se estende a todos os seus limites e quando o faz, é de maneira seletiva. Esse é um dos desafios do sistema: diminuir a distribuição desigual dos serviços de saúde, uma vez que eles estão concentrados nas regiões mais desenvolvidas do país, que também internamente apresentam disparidades.

Outro complicador é que o sistema público utiliza serviços privados, como serviços hospitalares e ambulatoriais pagos diretamente pelo SUS, além de reembolso de medicamentos e atendimentos de planos e seguros de saúde privados. A forma como ocorre essa associação, normalmente 
privilegia o atendimento privado, contradizendo, entre outros, o princípio de igualdade ao acesso à saúde.

Merece destaque, ainda, a questão do subfinanciamento crônico do SUS. Os recursos financeiros são insuficientes para financiamento do sistema, oriundos dos impostos e contribuições sociais, inclusive uma delas, criada em 1997 exclusivamente para financiar a Saúde (a Contribuição Provisória sobre a Movimentação Financeira - CPMF), mas foram utilizados para outros setores, em detrimento dessa mesma Saúde. Desde 2007, tal contribuição social foi revogada e os fundos previamente destinados a ela não foram repostos.

A despesa federal com saúde tem aumentado, desde 2003, em termos nominais, mas fica aquém, em relação ao crescimento da inflação. Em 2007, os gastos com saúde correspondiam a apenas $8,4 \%$ do produto interno bruto, em que a proporção pública com despesas em saúde foi de $41 \%$, valor baixo se comparado com outros países como Reino Unido (82\%), Itália (77,2\%), Espanha (71,8\%), EUA (45,5\%) e México (46,9\%) (PAIM et al., 2011).

Em Guarulhos, o demonstrativo financeiro elaborado pela Prefeitura sobre o orçamento investido na Saúde, segundo a esfera de Governo é mostrado na Tabela 05, que abrange o período de 2005 a 2009. Segundo ela, o maior custeador da Saúde é o município cuja contribuição no período variou entre $68,3 \%$ a $65,5 \%$ do total dos gastos.

Tabela 05 - Valores financeiros destinados a saúde por esfera de governo (reais).

\begin{tabular}{|r|r|r|r|r|r|r|r|}
\hline & \multicolumn{2}{|c|}{ Município } & \multicolumn{2}{c|}{ Estaduais } & \multicolumn{2}{|c|}{ Federais } & \multirow{2}{*}{ Total } \\
\hline & Absoluto & $\%$ & Absoluto & $\%$ & Absoluto & $\%$ & \\
\hline 2005 & $156.558 .316,87$ & 68,3 & 0 & 0 & $72.632 .731,41$ & 31,7 & $229.191 .048,28$ \\
\hline 2006 & $195.501 .251,57$ & 66 & $1.559 .866,60$ & 0,5 & $99.337 .430,45$ & 33,5 & $296.398 .548,62$ \\
\hline 2007 & $200.768 .016,49$ & 64,1 & $3.513 .773,33$ & 1,1 & $108.906 .907,35$ & 34,8 & $313.188 .697,17$ \\
\hline 2008 & $252.158 .536,84$ & 65,6 & $1.043 .454,29$ & 0,3 & $131.233 .812,13$ & 34,1 & $384.435 .803,26$ \\
\hline 2009 & $289.420 .937,00$ & 65,5 & $3.444 .628,94$ & 0,8 & $149.153 .934,60$ & 33,7 & $442.019 .500,54$ \\
& & & & & & & \\
\hline
\end{tabular}

Fonte: PMG (2010). 
Essa diminuição deveu-se ao aumento da proporção dos recursos advindos do Governo Federal, que era de 31,7\% em 2005 e chegou a 33,7\% em 2009, assim como a do Governo Estadual. Este não tinha gastos em 2005; no ano seguinte passou para 0,5\%, chegando à maior contribuição do período em 2007, quando era $1,1 \%$, tendo reduzido para $0,3 \%$ em 2008, voltando a subir até $0,8 \%$ em 2009, do total dos gastos em Guarulhos.

Os valores que constituem a Tabela 05 foram publicados no Plano Municipal de Saúde elaborado pela Prefeitura, para o período de 2010 a 2013, em que os dados são distintos dos disponibilizados pelo SEADE, conforme a Tabela 06; diferem, também, daqueles apresentados pela empresa contratada para fazer a revisão do Plano Diretor, que produziu, sobre o município, demonstrativo das despesas por órgão e função, entre 2006 e 2010.

Tabela 06 - Total de Despesas Municipais - Saúde (Em reais)

\begin{tabular}{|l|r|}
\hline Ano & Valores \\
\hline 2005 & sem dados \\
\hline 2006 & $414.399 .988,00$ \\
\hline 2007 & $417.674 .678,00$ \\
\hline 2008 & $458.793 .291,00$ \\
\hline 2009 & $517.038 .830,00$ \\
\hline
\end{tabular}

Fonte: SEADE

Conforme esse demonstrativo, a receita total da Prefeitura apresentou a taxa de crescimento anual de $39,02 \%$ em 2006, 10,75\% em 2007, 12,92\% em 2008, 13,79\% em 2009 e 14,31\% em 2010. Se, por um lado, em sintonia com o aumento da receita as despesas com saúde pelo município expandiram-se em valores absolutos, por outro lado, em dados relativos ela diminuiu, conforme a Tabela 07, em que as despesas municipais com saúde atingiram o maior patamar em 2007 e foi de $21,5 \%$. No ano seguinte, regrediu e chegou a $19,9 \%$, caindo para $18 \%$ em 2009 e, com uma mínima variação negativa manteve-se, praticamente, no mesmo patamar. 
Tabela 07 - Despesas da Secretaria Municipal de Saúde - 2006 a 2010 (reais).

\begin{tabular}{|c|c|c|}
\hline Ano & Absoluto & $\%$ \\
\hline 2006 & 262.656 .748 & 18,386 \\
\hline 2007 & 329.820 .000 & 21,468 \\
\hline 2008 & 349.332 .000 & 19,942 \\
\hline 2009 & 362.126 .201 & 17,986 \\
\hline 2010 & 454.588 .380 & 17,981 \\
\hline
\end{tabular}

Fonte: Pilotto et al (2012).

Além da diferença entre os dados apresentados nos diferentes órgãos, o que dificulta a análise, há, também, os investimentos indiretos como em saneamento, habitação e meio ambiente, que refletem nos gastos de saúde diretamente.

No censo 2010, o grau de urbanização do município atingiu 100\% e o número de habitantes 1.221.979, resultado, quase que exclusivamente do crescimento natural, que foi de 1,41\%, entre 2000 e 2010, inferior aos $2,49 \%$ da década anterior, conforme se vê na Tabela 08. Apesar da queda, o índice é maior do que a média da RMSP e ESP, bem como ocorre com outros dados associados à Saúde dos munícipes guarulhenses, reunidos na Tabela 08. Percebe-se que a maioria avançou, estando, porém, ainda em desvantagem ao ser comparados os outros recortes espaciais.

Assim como no Brasil, a dinâmica demográfica do município tem se alterado, resultando em mudanças na estrutura etária da população, que se relaciona ao declínio das taxas de mortalidade e de fecundidade, como se observa nas Tabelas 08 e 09. Nesta percebe-se que na última década, reduziu a proporção de crianças e adolescentes e aumentou a população de adultos e idosos, mudanças que implicam novas demandas das políticas públicas específicas, entre elas, saúde, educação e lazer.

Ao considerar a distribuição da população por faixa etária entre os bairros, constata-se que as maiores desproporções entre eles se referem às crianças com idades entre 1 e 11 anos e idosos, seguidos dos adolescentes, motivos que fizeram com que se optasse por construir o conjunto de anamorfoses, que formam a Figura 14, para contribuir na leitura e interpretação das informações. 
Tabela 08 - Estatísticas vitais de Guarulhos, RMSP e ESP

\begin{tabular}{|c|c|c|c|c|}
\hline \multirow{2}{*}{ DADOS } & \multicolumn{2}{|c|}{ GUARULHOS } & \multirow{2}{*}{$\begin{array}{l}\text { RMSP } \\
2010\end{array}$} & \multirow{2}{*}{ ESP } \\
\hline & 2000 & 2010 & & \\
\hline $\begin{array}{l}\text { Taxa Geométrica de Crescimento Anual da } \\
\text { População - 2000/2010 (\% ao ano) }\end{array}$ & 2,49 & 1,41 & 0,97 & 1,09 \\
\hline Grau de Urbanização (\%) & 97,85 & 100,00 & 98,86 & 95,94 \\
\hline Natalidade (por mil habitantes) & 22,32 & 16,75 & 15,76 & 14,59 \\
\hline $\begin{array}{l}\text { Fecundidade Geral } \\
\text { (por mil mulheres entre } 15 \text { e } 49 \text { anos) }\end{array}$ & 75,24 & 56,84 & 53,71 & 51,12 \\
\hline $\begin{array}{l}\text { Mortalidade de Mulheres em Idade Fértil (Por cem } \\
\text { mil mulheres entre } 15 \text { e } 49 \text { anos) }\end{array}$ & 148,41 & 121,51 & 112,15 & 113,54 \\
\hline $\begin{array}{l}\text { Mães Adolescentes } \\
\text { (com menos de } 18 \text { anos) (\%) }\end{array}$ & $s / d$ & 6,57 & 6,37 & 6,96 \\
\hline $\begin{array}{l}\text { Mães que Tiveram Sete e Mais Consultas de Pré- } \\
\text { Natal (\%) }\end{array}$ & $\mathrm{s} / \mathrm{d}$ & 70,13 & 75,39 & 78,11 \\
\hline $\begin{array}{l}\text { Nascimentos de Baixo Peso } \\
\text { (menos de } 2,5 \mathrm{~kg})(\%)\end{array}$ & $s / d$ & 9,51 & 9,39 & 9,15 \\
\hline Gestações Pré-Termo (\%) & $\mathrm{s} / \mathrm{d}$ & 7,94 & 8,79 & 8,67 \\
\hline Índice de Envelhecimento (\%) & 19,44 & 33,69 & 48,59 & 53,86 \\
\hline População com 60 Anos e Mais (\%) & 5,69 & 8,23 & 10,64 & 11,55 \\
\hline População com Menos de 15 Anos (\%) & 29,26 & 24,43 & 21,95 & 21,48 \\
\hline $\begin{array}{l}\text { Mortalidade Geral (por local de residência) } \\
\text { (por mil habitantes) }\end{array}$ & 5,74 & 5,5 & 5,96 & 6,39 \\
\hline $\begin{array}{l}\text { Mortalidade Infantil } \\
\text { (por mil nascidos vivos) }\end{array}$ & 20,98 & 12,67 & 11,80 & 11,86 \\
\hline $\begin{array}{l}\text { Mortalidade da População entre } 15 \text { e } 34 \text { Anos (por } \\
\text { cem mil habitantes nessa faixa etária) }\end{array}$ & 269,76 & 129,27 & 119,10 & 117,98 \\
\hline $\begin{array}{l}\text { Mortalidade da População de } 60 \text { Anos e Mais (por } \\
\text { cem mil habitantes nessa faixa etária) }\end{array}$ & $4.271,93$ & $3.853,66$ & $3.552,87$ & $3.638,16$ \\
\hline $\begin{array}{l}\text { Mortalidade materna } \\
\text { (por cem mil nascidos }\end{array}$ & 29,31 & 48,92 & 49,02 & 45,55 \\
\hline
\end{tabular}

Fonte: SEADE

Tabela 09 - Estrutura etária da população

\begin{tabular}{|l|r|r|r|r|}
\hline \multirow{2}{*}{ Faixa etária (anos) } & \multicolumn{2}{|c|}{2000} & \multicolumn{2}{c|}{2010} \\
\cline { 2 - 5 } & População & \multicolumn{1}{c|}{$\%$} & População & \multicolumn{1}{c|}{$\%$} \\
\hline Menor 1 & 21.539 & 2,01 & 18.616 & 1,52 \\
\hline Crianças (1 a 11) & 228.951 & 21,34 & 214.716 & 17,57 \\
\hline Adolescentes (12 a 17) & 127.077 & 11,85 & 128.728 & 10,53 \\
\hline Adultos (18 a 59) & 634.128 & 59,11 & 760.123 & 62,20 \\
\hline Idoso (maior 60) & 61.023 & 5,69 & 99.796 & 8,17 \\
\hline Total & 1.072 .718 & 100,00 & 1.221 .979 & 100,00 \\
\hline
\end{tabular}

Fonte: Censo 2000, 2010, IBGE. 
Proporção em relação a população total (\%) - 2010

Bairros - Guarulhos

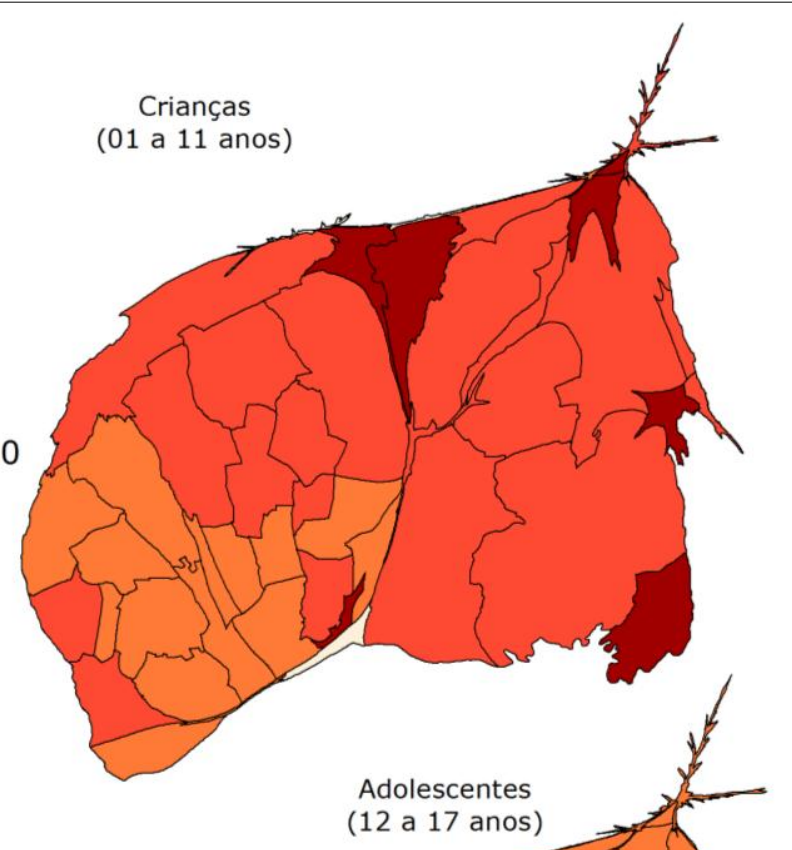

$\geq 20$

$\geq 15-20$

$\geq 10-15$

$\geq 5-10$

$<5$

Área dos bairros proporcional a população total -2010

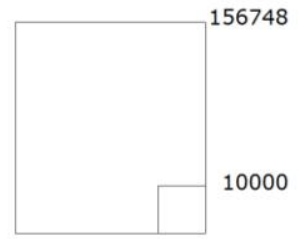

(01 a 11 anos)

Fonte: IBGE, Censo 2010. Elaborado com softwares SCAPE TOAD e ARCGIS. Org. Maria Cristina de Jesus Novaes

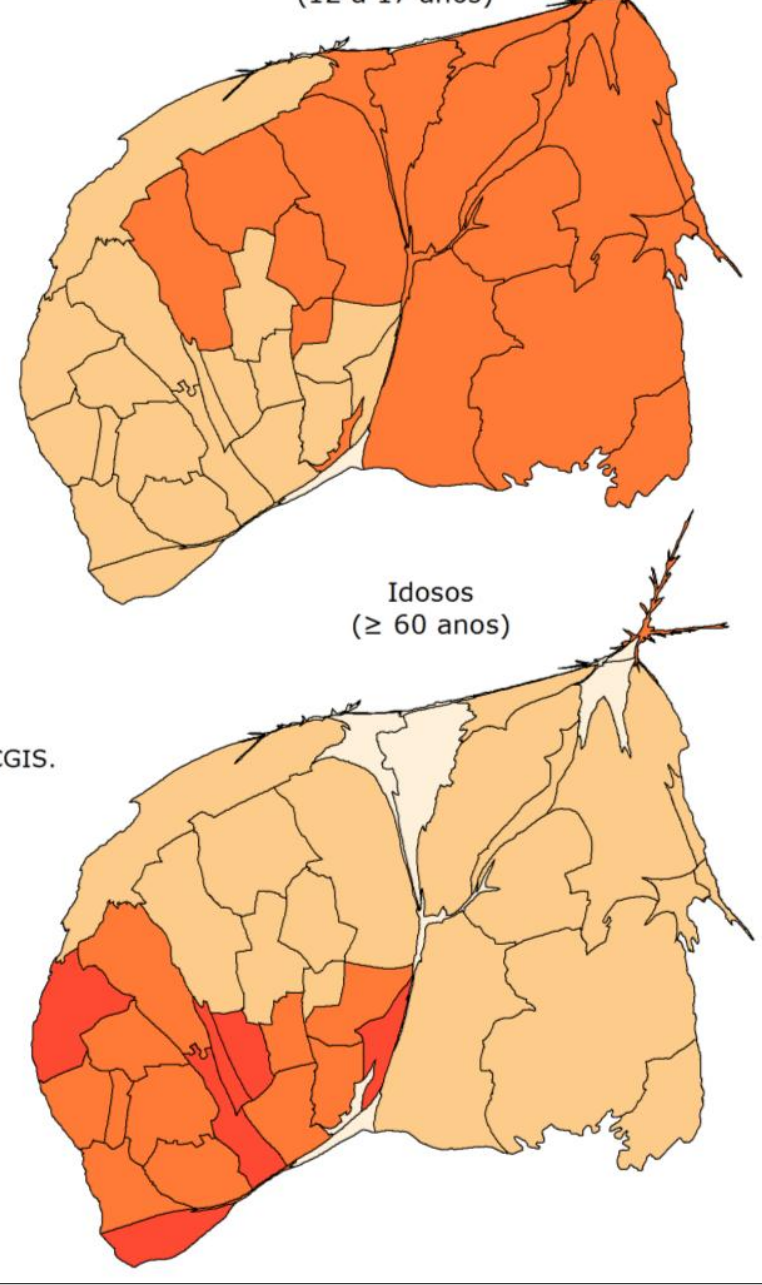

Figura 14 - Faixas etárias (crianças, adolescentes e idosos) - Guarulhos. 
Observa-se, conforme a Figura 14, que a proporção de crianças entre 10 e $15 \%$ se concentra no conjunto de bairros situados a oeste do município. Entre as exceções, com taxas que variam de 15 a 20\%, vale destacar os bairros de Itapegica e Jardim Vila Galvão, localizados a sudoeste, que também apresentam número relativamente elevado de moradias precárias, conforme se nota adiante. Essa última taxa é a da grande maioria dos bairros do município.

Concentrando, proporcionalmente, o maior número de crianças, que superou os $20 \%$, os bairros da Água Chata, Itaim, Invernada, Bananal e Mato das Cobras, estes dois últimos, também apresentam comparativamente o maior número de pessoas em moradias precárias. Parte dos bairros que concentram mais crianças possui os menores índices de idosos, que não chega a $5 \%$ dos habitantes.

$\mathrm{Na}$ maioria dos bairros, esse número corresponde de 5 a $10 \%$ habitantes, sendo um pouco maior, entre 10 e 15\%, nos bairros posicionados a oeste do município, que abriga, ainda, a Ponte Grande, Centro, Maia, Paraventi, Vila Galvão e Cecap, em que o índice variou entre 15 e $20 \%$

No caso dos adolescentes há dois grandes conjuntos: um, cuja taxa correspondeu à porcentagem de 5 a $10 \%$, em que a maioria se posiciona na parte oeste da cidade, onde também há bairros, com índices entre 10 e $15 \%$, que se unem aos demais bairros, formando outro grande conjunto.

Os serviços ligados à Saúde do município, assim como no Brasil, dividem-se entre os públicos, para os quais os serviços são financiados e providos pelo Estado em suas três esferas: Federal, Estadual e Municipal; nos privados (com fins lucrativos ou não), no qual os serviços são financiados de diversas maneiras, com recursos públicos ou privados; e no suplementar, com diferentes tipos de planos privados de saúde e de apólices de seguro, além de subsídios fiscais (PAIM et al., 2011). 
Os objetos que compõem os equipamentos de saúde são formados por 607 estabelecimentos, 480 dos quais são privados e os demais públicos.

A maioria dos serviços referentes à Saúde é gerida pela própria Prefeitura que, do total de estabelecimentos, é responsável por 124 deles (DATASUS), além de manter convênios com hospitais filantrópicos (Hospital Stella Maris e Maternidade Jesus, José e Maria) e com clínicas de hemodiálise privadas (Centro Integrado de Nefrologia - Cine e Assistência Médica Nefrológica de Guarulhos) (PMG, 2010). O Governo Estadual é responsável por dois hospitais e pela farmácia de medicamentos de alto custo (PMG, 2010).

Atendo-se aos objetos públicos, especificamente às unidades básicas de saúde, as policlínicas e os hospitais, os quais são os responsáveis pelo atendimento da população em geral; e os hospitais privados, que podem disponibilizar atendimento pelo SUS. Foram construídos mapas que mostram a distribuição deles pelo município, apresentados na Figura 15.

Ao observar a Figura 15, depreende-se que os hospitais, num total de 12 , estão concentrados nos bairros mais centrais, exceção feita ao Hospital Municipal Pimentas-Bonsucesso, situado na parte leste do município, no bairro dos Pimentas, inaugurado em 2006. Na Tabela 10 é apresentado o gestor responsável por cada hospital, bem como o total de leitos (1.317) disponíveis em cada um deles, distinguindo aqueles vinculados ao SUS (837), que são atendidos pelos hospitais públicos (estaduais e municipais) e por filantrópicos.

A Fundação Seade mostra números distintos de leitos que atendem o SUS no município, segundo a qual havia em 2011, 1.413 leitos. Também mostra - vide o Gráfico 07 - o número de leitos proporcionais a mil habitantes, no período de 1995 a 2011, percebendo-se que não acompanharam o crescimento populacional, que chegou quase a dois leitos para cada 1.000 habitantes, os quais, com oscilação ora positiva ora negativa, foram reduzidos, chegando, em 2011, à taxa de 1,14 leitos para aquele mesmo número de habitantes. 


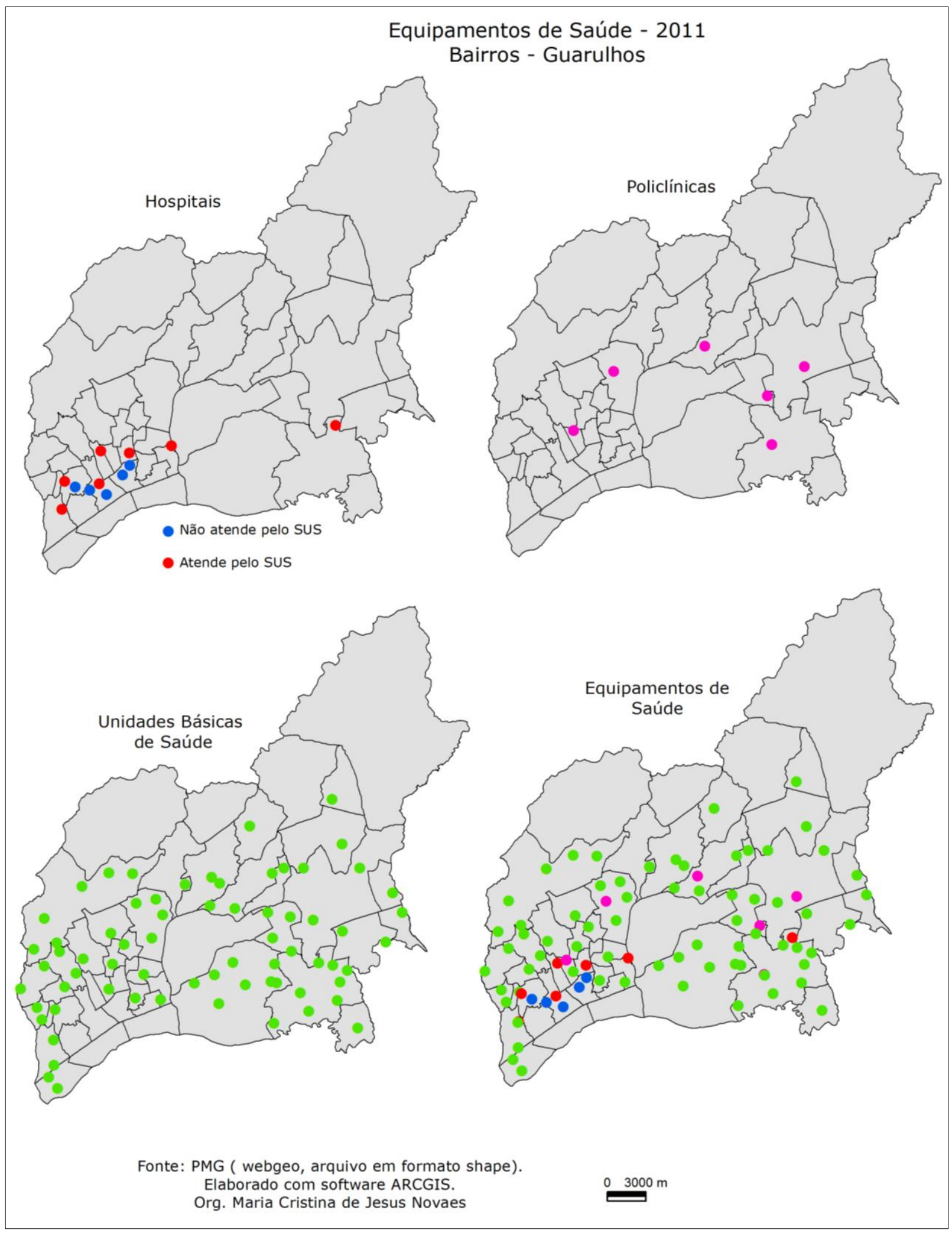

Figura 15 - Equipamentos de Saúde - Guarulhos 
Tabela 10 - Hospitais Guarulhos

\begin{tabular}{|c|c|c|c|}
\hline \multirow[t]{2}{*}{ Hospital } & \multirow[t]{2}{*}{ Gestão } & \multicolumn{2}{|c|}{ Leitos } \\
\hline & & Gerais & SUS \\
\hline 1. Hospital Municipal da Criança & Municipal & 48 & 48 \\
\hline 2. Hospital Municipal de Urgências & Municipal & 74 & 74 \\
\hline 3. Hospital Municipal Pimentas - Bonsucesso & Municipal - UNIFESP & 117 & 117 \\
\hline $\begin{array}{l}\text { 4. Complexo Hospitalar Padre Bento de } \\
\text { Guarulhos }\end{array}$ & Estadual & 126 & 126 \\
\hline 5. Hospital Geral de Guarulhos & $\begin{array}{l}\text { Estadual, sob gestão } \\
\text { da Organização } \\
\text { Social da Santa Casa } \\
\text { de São Paulo }\end{array}$ & 270 & 270 \\
\hline 6. Hospital Stella Maris & $\begin{array}{l}\text { Filantrópico com } \\
\text { atendimento misto, } \\
\text { convênios, particular } \\
\text { e SUS, contrato com } \\
\text { o município. }\end{array}$ & 186 & 117 \\
\hline 7. Maternidade Jesus José e Maria & $\begin{array}{l}\text { Filantrópico com } \\
\text { atendimento } 100 \% \\
\text { SUS, contrato com o } \\
\text { município. }\end{array}$ & 85 & 85 \\
\hline 8. Hospital Bom Clima & Privado & 77 & 0 \\
\hline 9. Hospital Carlos Chagas & Privado & 164 & 0 \\
\hline 10. Hospital Casa de Saúde Guarulhos & Privado & 47 & 0 \\
\hline 11. Hospital UNIMED de Guarulhos & Privado & 66 & 0 \\
\hline 12. Hospital UNIMED de Guarulhos & Privado & 57 & 0 \\
\hline Total & & 1317 & 837 \\
\hline
\end{tabular}

Fonte: PMG (2010) e DATASUS (2012).

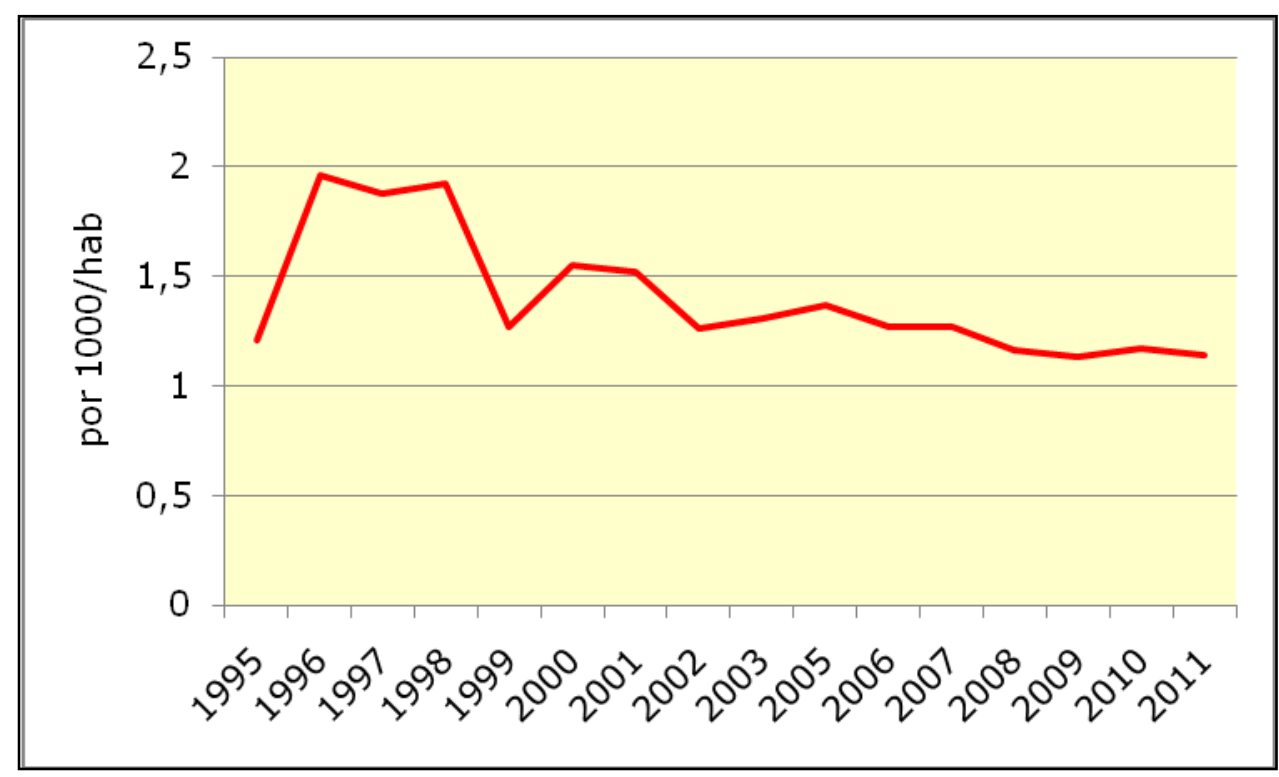

Gráfico 07 - Leitos SUS (SEADE). 
São sete hospitais que atendem o SUS e realizam serviços de urgência e emergência; completam esse atendimento seis policlínicas com algumas especialidades, geridas pelo município e o Serviço de Atendimento Móvel de Urgência - SAMU (PMG, 2010).

Percebe-se, a partir da figura 15, que as policlínicas atendem em parte os serviços hospitalares, inexistentes em muitas regiões da cidade, dando a primeira assistência em casos de emergência (PMG, 2010). A diferença entre as policlínicas e os hospitais, é que estes dispõem de UTIs e de outros serviços e diagnósticos de maior complexidade.

$\mathrm{O}$ atendimento inicial para qualquer especialidade ou tratamento oferecido pelo município passa pela unidade básica de Saúde (UBS), mais próxima da casa das pessoas. As UBSs subdividem-se em dois modelos: o tradicional e o programa saúde da família (PSF), que se distingue porque há o agente comunitário de Saúde, que é morador da região e visita as famílias cadastradas no programa para identificar situações de risco, em que a intenção é prevenir as doenças e promover a saúde.

Em ambos os modelos há atendimento para as áreas de clínica médica, pediatria, ginecologia, odontologia e algumas contam também com serviços especializados. No caso das UBSs com o Programa Saúde da Família, a assistência é realizada pelo médico generalista, além dos demais profissionais. UBS apresenta área de atuação territorial definida pela Prefeitura, distinta da divisão de bairros, mostrada na Figura 16.

Segundo a Política Nacional de Atenção Básica, para a UBS tradicional o adequado é o máximo de 30.000 habitantes e a UBS com a Estratégia Saúde da Família é de 12.000 habitantes (PMG, 2010). Com base nisso, foram construídos os mapas para analisar esse parâmetro das UBSs. Cabe ressaltar que, além do número ideal de pessoas, parâmetro que melhoraria a discussão, estão os dados sobre o histórico de uso pelos habitantes da UBS, bem como instrumentos que ajudem a mensurar a qualidade desses serviços do ponto de vista da população.

O município tem 67 Unidades Básicas de Saúde, sendo 30 do modelo tradicional, a que se somaram mais três, que estão em transição 
para o modelo saúde da família, com 34 unidades, atualmente. De acordo com a Figura 15, percebe-se que, em ambos os modelos, há várias UBSs que ultrapassam o número de pessoas considerado ideal. No caso das UBSs com modelo tradicional, concentradas no oeste da cidade, muitas enfrentam problemas de superlotação e, assim também, mais outras quatro localizadas na parte leste e nordeste do município.

No caso das UBSs baseadas no modelo saúde da família, ausentes nos bairros próximos ao centro, apresentam-se com número de pacientes superiores ao ideal, principalmente naqueles bairros que rodeiam o Aeroporto; entre as poucas unidades situadas na parte oeste, também a quantidade de pessoas é acima do desejável.

Ressalta-se que muitas dessas UBSs compartilham o território com muitas moradias com diferentes precariedades, discutidas adiante, o que eleva a frequência de uso delas.

Entre os problemas vividos pela população em boa parte das UBSs, além da superlotação, estão as más condições de atendimento; há demora para marcação de consulta, há falta de médicos, de medicamentos e até de higiene.

O modelo de atendimento baseado na saúde da família, esta em estruturação, espera-se que, além da necessidade de superação do problema de superlotação, concretize a melhoria no atendimento da saúde, o que dependerá das ações que movimentaram tais objetos, assim como outros referentes à habitação, educação e à infraestrutura do bairro.

Com relação às ações em saneamento básico, em 2011, 93\% das unidades domiciliares contavam com ligações de água, segundo Pilotto et al (2012), mas ainda parte considerável dos bairros enfrenta o rodízio, em que o número de dias com e sem água varia de um para outro bairro. 0 atendimento na coleta de esgoto e no tratamento sofreu alterações, em 2011, quando a extensão da rede coletora, atendia $80 \%$ da demanda domiciliar, a partir desse ano de 2012, 35\% desse esgoto passou a ser tratado. 


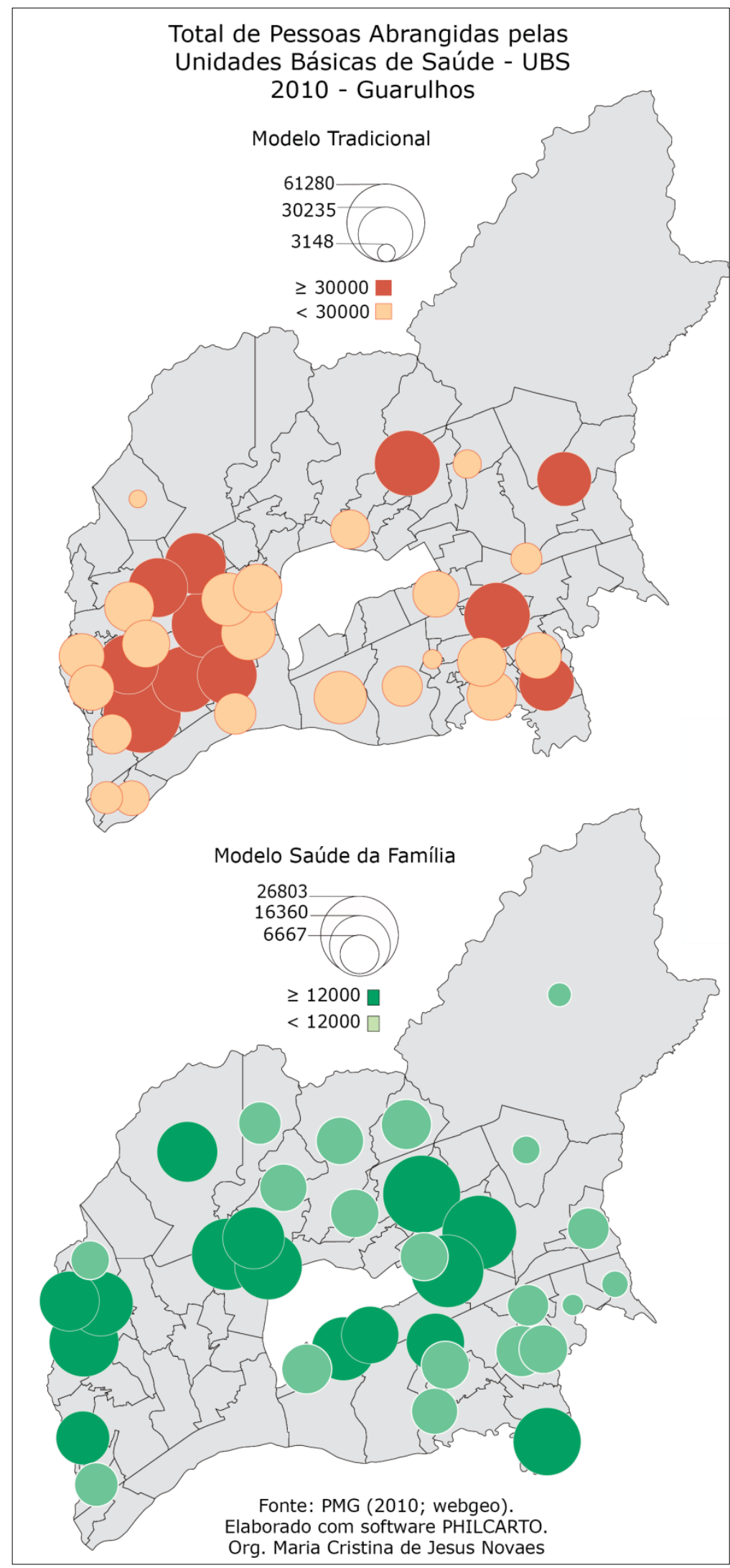

Figura 16 - Total de pessoas abrangidas pelas UBSs - Guarulhos 
As estações de tratamento recém-inauguradas atendem às ocupações mais antigas dos bairros do São João, Presidente Dutra e Pimentas, que têm praticamente toda sua área atendida pela rede coletora. Entretanto, nesses bairros melhor atendidos, ainda existem áreas com alta densidade demográfica, que não usufruem do sistema coletivo de esgoto (PILOTTO et al,op.cit.).

Como mostrado, grande parte do esgoto coletado, não é tratado, com isso vai para os cursos d'água; assim, os investimentos para ampliação da rede de coleta de esgoto ficam comprometidos pela falta de destino adequado ao esgoto bruto, conforme Pilotto et al (op.cit).

Praticamente, a discussão dos objetos ligados à Saúde, assim como aos demais serviços sociais, muitas vezes resultam na discussão do acesso a eles, o que é importante, mas não apontam instrumentos que mensurem diretamente a qualificação desses serviços. Atualmente, vem sendo estabelecidos indicadores para áreas da Educação e da Saúde, que precisam ser melhorados em diversos aspectos, como a forma pela qual eles são obtidos, as concepções que movem as avaliações, como servirão para modificar as ações ora praticadas e a satisfação da população sobre tais serviços.

\subsubsection{Educação}

Entre as políticas que gerem objetos ligados aos serviços públicos essenciais, a Educação foi uma das que mais sofreram reformas, sobretudo nas duas últimas décadas, movidas por ações vinculadas ao ideário neoliberal e aplicadas pelo Estado em suas três esferas, com a participação dos organismos internacionais, entre eles o Banco Mundial e Fundo Monetário Internacional - FMI. Para tal, vários instrumentos normativos foram instituídos durante o Governo Federal do Presidente Fernando Henrique Cardoso, focados, principalmente, no Ensino 
Fundamental que, nos mandatos do Presidente Luís Inácio Lula da Silva, se estenderam para o Ensino Básico em algumas metas, mas a essência das ações foi mantida.

Como instrumentos normativos, destacam-se o Plano Decenal de Educação para Todos (1993), substituído pelo Plano Nacional de Educação 2011-2020, a Lei de Diretrizes e Bases da Educação Nacional (LDBEN/1996), o Fundo de Manutenção e Desenvolvimento do Ensino Fundamental e de Valorização do Magistério (FUNDEF/1996) que, a partir de 2007, foi modificado para o Fundo de Manutenção e Desenvolvimento da Educação Básica e de Valorização dos Profissionais da Educação (FUNDEB), o Plano Nacional de Educação (PNE/2001) e o Plano de Desenvolvimento da Educação.

Observa-se que os objetos e dados sobre Educação do Município estão estruturados em consonância com essa política. Os estabelecimentos de ensino subdividem-se entre os da rede particular e da rede pública, atendida, sobretudo, pelas esferas estadual e municipal.

As ações realizam-se em consonância com a LDB (Lei de Diretrizes e Bases da Educação Nacional - 9394/96), que instituiu o caráter obrigatório para o ensino fundamental e de responsabilidade dos municípios, resultando na municipalização. A Educação Infantil sob a mesma gestão, segundo a LDB não tem caráter obrigatório, e cujos planos de ação para a Educação acenam com o aumento gradativo no atendimento desse nível, assim como o Ensino Médio, que é de responsabilidade dos Estados. À União, compete o Ensino Superior, que pode ser oferecido por Estados e Municípios, e cabe a ela, também, autorizar e fiscalizar as instituições privadas de ensino superior.

O Governo Federal conta apenas com um campus da Universidade Federal de São Paulo - UNIFESP, instalado em 2006, no bairro dos Pimentas, que ainda funciona de modo precário, o que dificulta, em muito, as condições de ensino-aprendizado. Há, ainda, outros 12 estabelecimentos de ensino superior privados, entre faculdades e 
universidades, que oferecem cursos de graduação, pós-graduação e especialização nas áreas de Humanas, Exatas e Biológicas.

Observa-se, na Tabela 11, que, entre as redes estadual, municipal e a particular, ocorreram mudanças significativas na distribuição das matrículas, na última década. Destaca-se o processo de municipalização, que diminuiu a atuação da esfera estadual no ensino fundamental no Ciclo I, e o crescimento do atendimento da rede particular, justificado pela expansão do consumo, somado à pretensa busca de melhores condições de ensino, diante da precarização do ensino público. Houve, ainda, o fortalecimento do ensino privado, promovido pela Prefeitura, por meio de convênios. As redes de ensino oferecem também atendimento à Educação de Jovens e Adultos e Educação Especial, não analisados na presente pesquisa.

Na Figura 17, ao observar a distribuição das escolas de acordo com a sua gestão, depreende-se que aquelas vinculadas à Rede Estadual estão distribuídas por todos os bairros. A Rede Municipal, que teve grande expansão na última década, apresenta-se, em menor número, junto às áreas centrais. A Rede Particular é a que mostra maior desigualdade de distribuição entre os bairros da cidade, pois estão concentradas na parte oeste do município, refletindo as consequências da lei da oferta e da procura, visto ser ali que se abriga a população de, relativamente, maior poder aquisitivo. Engloba, ainda, a rede conveniada pela Prefeitura, que atende a Educação Infantil, percebendo-se que ela se pulveriza pelos bairros de Guarulhos, diferentemente das demais particulares; o maior número delas atende o bairro dos Pimentas.

No caso da Rede Estadual, que tinha como uma das metas principais a universalização do Ensino Fundamental, que implicaria a ampliação dos investimentos financeiros e do aparato estatal, isso ocorreu de forma contrária, e a justificativa do Governo apontava apenas como uma questão de ordem gerencial na distribuição dos recursos. 
Tabela 11 - Matrículas iniciais por nível e rede de ensino - 2000 e 2010.

\begin{tabular}{|c|c|c|c|c|}
\hline \multicolumn{5}{|c|}{ Educação infantil - Creche } \\
\hline & 2000 & $\%$ & 2010 & $\%$ \\
\hline Total & 1.522 & 100 & 21.134 & 100 \\
\hline Rede Estadual & 0 & 0 & 0 & 0 \\
\hline Rede Municipal & 351 & 23,06 & 10.452 & 49,45 \\
\hline Rede Particular & 1.171 & 76,93 & 10.682 & 50,55 \\
\hline \multicolumn{5}{|c|}{ Educação infantil - Pré-escola } \\
\hline Total & 25.892 & 100 & 34.788 & 100 \\
\hline Rede Estadual & 0 & 0 & 0 & 0 \\
\hline Rede Municipal & 20.058 & 77,47 & 26.054 & 74,89 \\
\hline Rede Particular & 5.834 & 22,53 & 8.734 & 25,11 \\
\hline \multicolumn{5}{|c|}{ Ensino fundamental - ciclo I - ( $1^{a}$ a $4^{a}$ séries $)$} \\
\hline Total & 95.076 & 100 & 99.377 & 100 \\
\hline Rede Pública & 85.329 & 89,8 & 81.972 & 82,5 \\
\hline Rede Estadual & 81.847 & 86,1 & 35.590 & 35,8 \\
\hline Rede Municipal & 3.482 & 3,7 & 46.382 & 46,7 \\
\hline Rede Particular & 9.747 & 10,2 & 17.405 & 17,5 \\
\hline \multicolumn{5}{|c|}{ Ensino fundamental - ciclo II ( $5^{a}$ a $8^{a}$ séries) } \\
\hline Total & 98.358 & 100 & 105.470 & 100 \\
\hline Rede Pública & 89.195 & 90,68 & 91.858 & 87,09 \\
\hline Rede Estadual & 89.195 & 90,68 & 91.858 & 87,09 \\
\hline Rede Municipal & 0 & 0 & 0 & $\underline{0}$ \\
\hline Rede Particular & 9.163 & 9,32 & 13.612 & 12,91 \\
\hline \multicolumn{5}{|c|}{ Ensino médio } \\
\hline Total & 55.836 & 100 & 61.707 & 100 \\
\hline Rede Estadual & 49.149 & 88,02 & 54.599 & 88,48 \\
\hline Rede Municipal & 0 & 0 & 0 & 0 \\
\hline Rede Particular & 6.687 & 11,98 & 7.108 & 11,52 \\
\hline
\end{tabular}

Fonte: IBGE/SEADE.

Entre as ações empreendidas incluem-se a precarização das relações trabalhistas dos profissionais da educação, redução dos níveis salariais, superlotação de salas, instituição da progressão continuada, a qual, na prática, resultou na promoção automática, que faz com que os alunos avancem, sem projeto qualificado de recuperação para aqueles que dela necessitam, além de outras medidas perversas. 


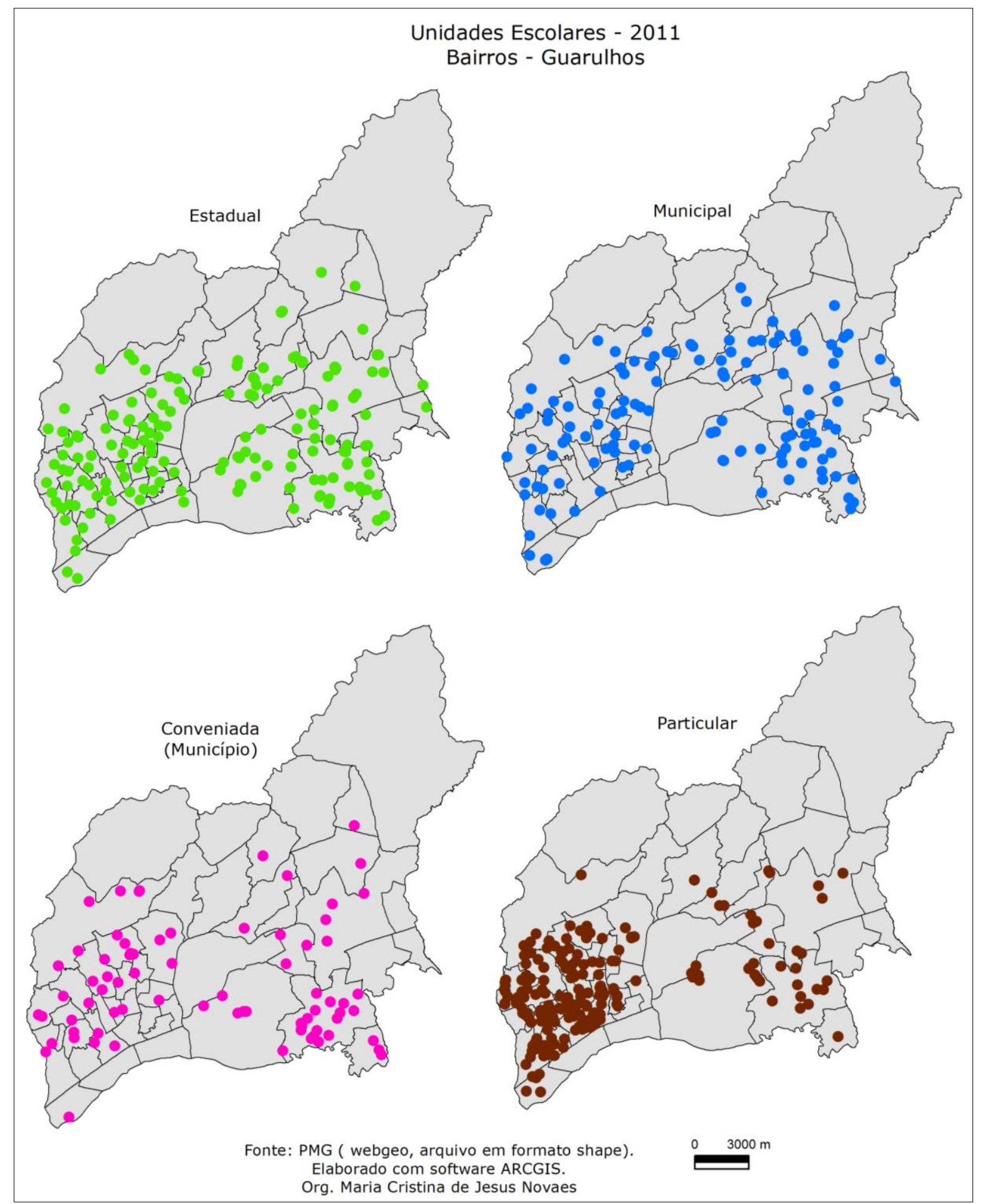

Figura 17 - Distribuição das escolas das redes estadual, municipal, conveniada e particular - Guarulhos. 
O resultado é que o acesso ocorreu, mas sem qualidade para a maioria dos alunos da rede. Silveira (2008) observa que o desmantelamento do Estado de bem-estar é mais uma forma de empobrecimento da população.

Ao todo, em 2011, eram 169 escolas estaduais, em 82 das quais era oferecido o Ensino Fundamental do Ciclo I, que sofreu grande redução no número de alunos matriculados. Segundo a Tabela 11, em 2000, eram $86,1 \%$ do total, que se reduziu para $35,8 \%$, no ano de 2010 (IBGE, CENSO ESCOLAR, 2011). As escolas do Ciclo II do Ensino Fundamental eram atendidas por 133 escolas, que atendiam 90,68\% das matrículas (2000), que declinaram para 87,09\% (2010), em função da ascensão da rede particular. 0 ensino médio era oferecido em 100 unidades escolares, as quais, em 2010 , contaram com $88,48 \%$ das matrículas que foram de $88,02 \%$ em 2000.

Ainda é expressivo o número de pessoas que não ingressam nesse nível de ensino, sendo uma das justificavas a necessidade de trabalhar. Com o processo de municipalização e com as medidas econômicas visando à diminuição de gastos, o Governo Estadual vem diminuindo sua atuação no ensino de Guarulhos, e os desdobramentos para o ensino aprendizado têm sido nefastos, confirmados por meio dos resultados de diferentes tipos de avaliação.

Atualmente, há escolas parcialmente ociosas, fechadas em alguns períodos do dia, o que inviabiliza o uso das bibliotecas, salas de informática, quadras e afins. Há, ainda, escolas em que parte das salas de aula está fechada.

Uma medida que amenizaria um pouco tal situação seria a redução significativa do número de alunos em sala de aula, já que vem diminuindo o número de pessoas em idade escolar para o Ensino Fundamental, mas isso implicaria a ampliação da contratação de profissionais, o que iria na contramão das ações praticadas pelos recentes governantes. Vale lembrar, que são apenas medidas pontuais, num grande problema estrutural que envolve a Educação brasileira. 
A Rede Municipal de ensino de Guarulhos conta 132 escolas próprias, de forma conjugada ou não: são 56 creches, 95 escolas da préescola e 97 do Ciclo I do Ensino Fundamental e mantém convênio com 74 particulares (CENSO ESCOLAR, 2011).

O número de matrículas na Educação Infantil nas creches, em 2000, era ínfimo, apenas 1.522 no total, perante a existência 66.500, com idade inferior a três anos, que teriam direito a esse atendimento (SEADE, IBGE). Em 2010, cresceu o número de alunos matriculados, totalizando 21.134 nas creches, das quais 49,45\% eram atendidas pela Rede Municipal e o restante na rede particular. Para tal, como mostrado, o Município optou pela associação da esfera pública e privada. Nas pré-escolas, também houve avanço no número de matrículas, no entanto, ele foi mais significativo na rede particular. Em 2000, ao todo, eram 25.892 matrículas, das quais $77,47 \%$ na Rede Municipal que, com o aumento do número total de matrículas para 34.788, reduziu essa proporção para 74,89\%, em 2010. Mesmo com o crescimento no atendimento a Educação Infantil, há ainda, praticamente, metade das crianças fora da escola nesse nível de ensino, se se considerar o total de crianças (110.525) com idade até cinco anos e o número total de matrículas (55.922).

As unidades escolares associadas ao Ensino Fundamental do Ciclo I, geridas pela Rede Municipal, começou em 1997 e, desde então, as matrículas tem se expandido. Elas eram apenas 3,5\% do total, em 2000, e subiram para 35,8\%, em 2010, instalando-se, principalmente, nos bairros periféricos para norte, nordeste e leste. Se, por um lado, contribuiu para diminuir a lotação das escolas estaduais, por outro, como apontado, fez com que algumas das unidades estaduais ficassem ociosas.

Tal situação poderia ter sido revertida, se os recursos financeiros despendidos para os novos objetos fossem direcionados para as carências da Educação Infantil, por exemplo, ao invés de recorrer a convênios, sobretudo pela importância do atendimento desse nível, como medida para a melhoria da educação em geral. No caso dos convênios, a parceria 
pública e privada, resulta, normalmente, na precarização dos serviços públicos.

Vale ressaltar que esse avanço da Rede Municipal no Ensino Fundamental e Infantil está vinculado às ações conjuntas com o Governo Federal, por meio do FUNDEF/FUNDEB, que redistribuiu recursos financeiros para os Municípios e Estados.

O mapa da Figura 17 focou-se na questão da distribuição dos objetos escolares pelo território, o que é insuficiente, por não considerar seu uso, para o que seriam necessárias outras variáveis, muitas delas indisponíveis. Nesse sentido, nas Figuras 18, 19 e 20 procurou-se associar o objeto a partir do nível de ensino, da proporção de crianças e jovens na idade escolar ideal, e da pré-escola em diante, adotando-se o número de alunos por escola, o que revela, parcialmente, uma das dificuldades do ensino, a superlotação de salas de aula.

No caso das creches, na Figura 18 fica expressa a dependência da rede conveniada, perante a ausência de unidades municipais em muitos bairros. Nas regiões que somam bairros populosos com índices mais elevados de crianças com idade inferior a três anos, evidencia-se o pequeno número de creches, como Taboão, Cumbica e Pimentas que, mesmo concentrando o maior número delas, mostram-se insuficientes para a população que precisariam atender.

Com relação ao atendimento na pré-escola, visto na Figura 19, onde foi associado o número de alunos por unidade escolar, fica evidenciado que elas são mais numerosas na parte leste e nordeste do município, assim como atendem o maior número de alunos por unidade escolar, correspondem aos bairros com os índices mais elevados (maior que $3 \%$ ) de crianças entre quatro e cinco anos. $\mathrm{Na}$ parte oeste, em que a proporção de crianças é inferior a $3 \%$ e os bairros são menos populosos, as unidades têm menores quantidades de alunos por escola. 


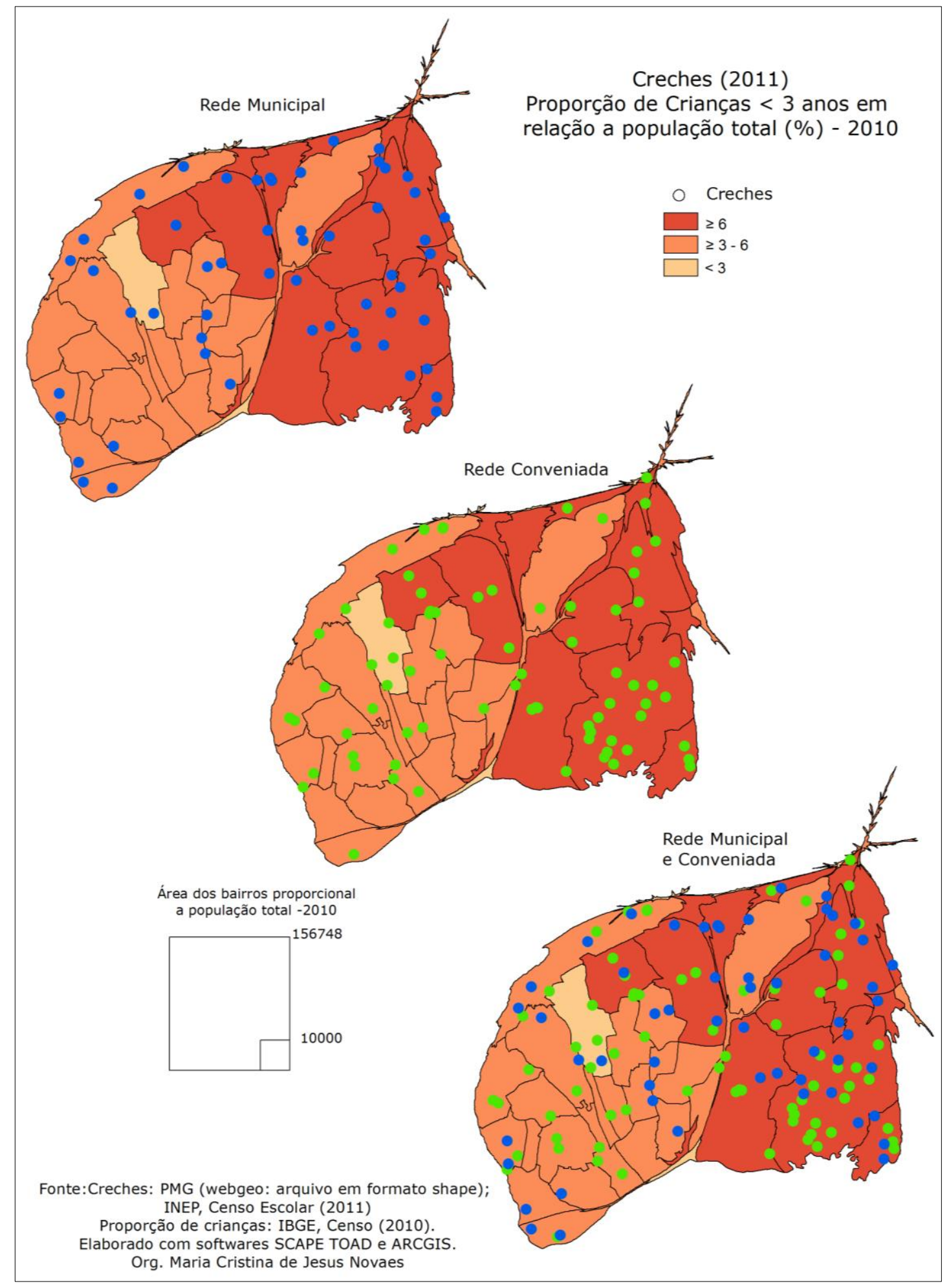

Figura 18 - Distribuição das creches municipais e da rede conveniada e proporção de crianças $<3$ anos - Guarulhos. 
Número de Alunos por Pré-escolas Municipais (2011)

Proporção de Crianças com 4 e 5 anos em relação

a População Total (\%) - 2010
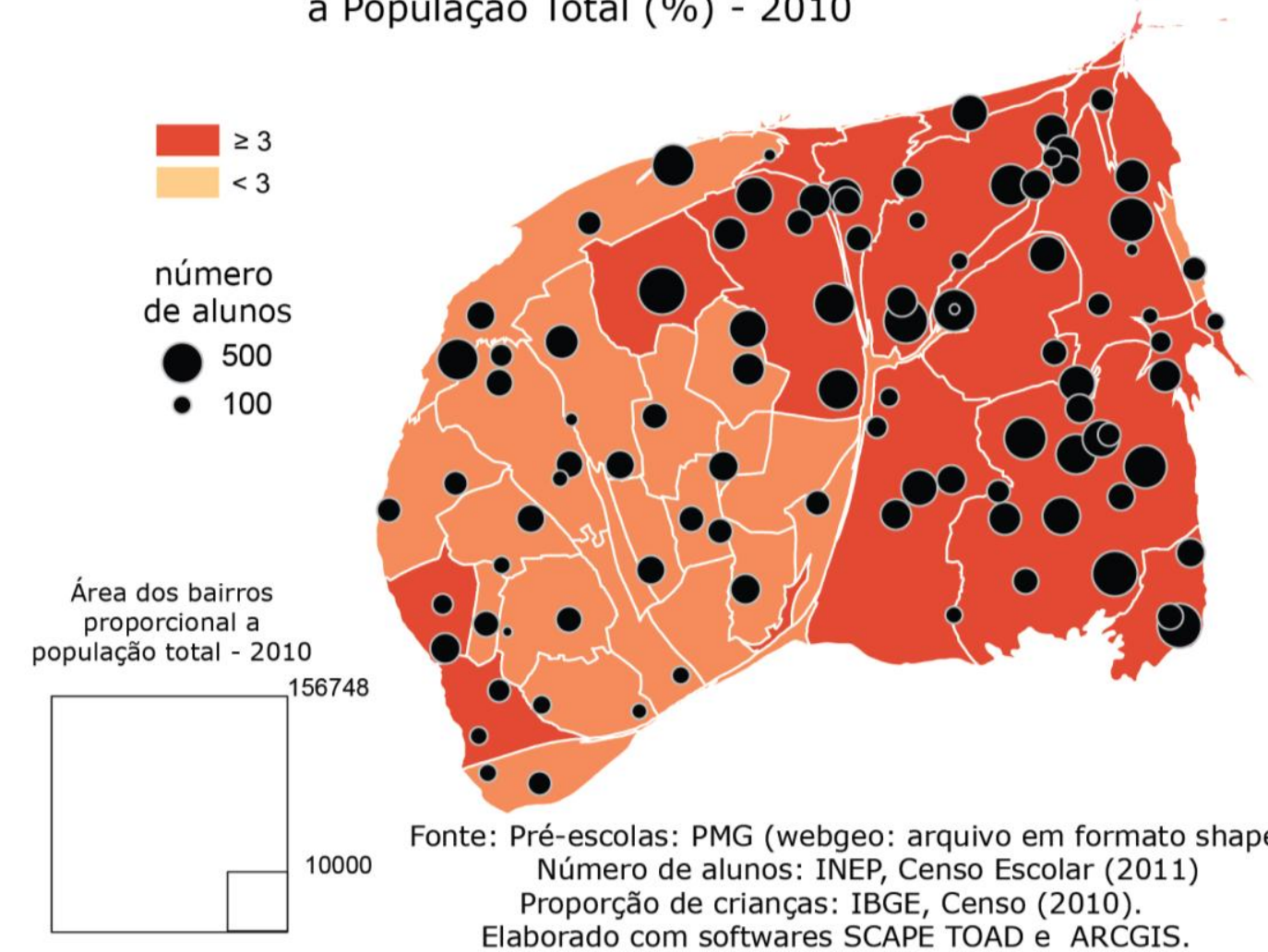

Fonte: Pré-escolas: PMG (webgeo: arquivo em formato shape); Número de alunos: INEP, Censo Escolar (2011)

Proporção de crianças: IBGE, Censo (2010).

Elaborado com softwares SCAPE TOAD e ARCGIS. Org. Maria Cristina de Jesus Novaes

Figura 19 - Número de alunos por pré-escolas municipais e proporção de crianças com 4 e 5 anos - Guarulhos.

As Escolas Municipais de Ciclo I, mostradas na Figura 20, estão concentradas nos bairros com maior proporção de crianças (superior a $8 \%$ ), também contam com mais alunos por unidade, os quais, em 2011, variavam de 35 a mais de 1300 alunos. No caso das Escolas Estaduais, distribuídas por toda cidade, as unidades no geral apresentaram menor número de alunos do que as da Rede Municipal, e variaram entre $28 \mathrm{e}$ 1.038 alunos por unidade. A quantidade de alunos por escola revela que para atender o processo de municipalização, o Município teve que elevar o número de estudantes por unidade escolar, visto que, atualmente, atende mais alunos do que a Rede Estadual e em menor número de escolas. Assim, há a inclusão de todos na escola, que é fator primordial, 


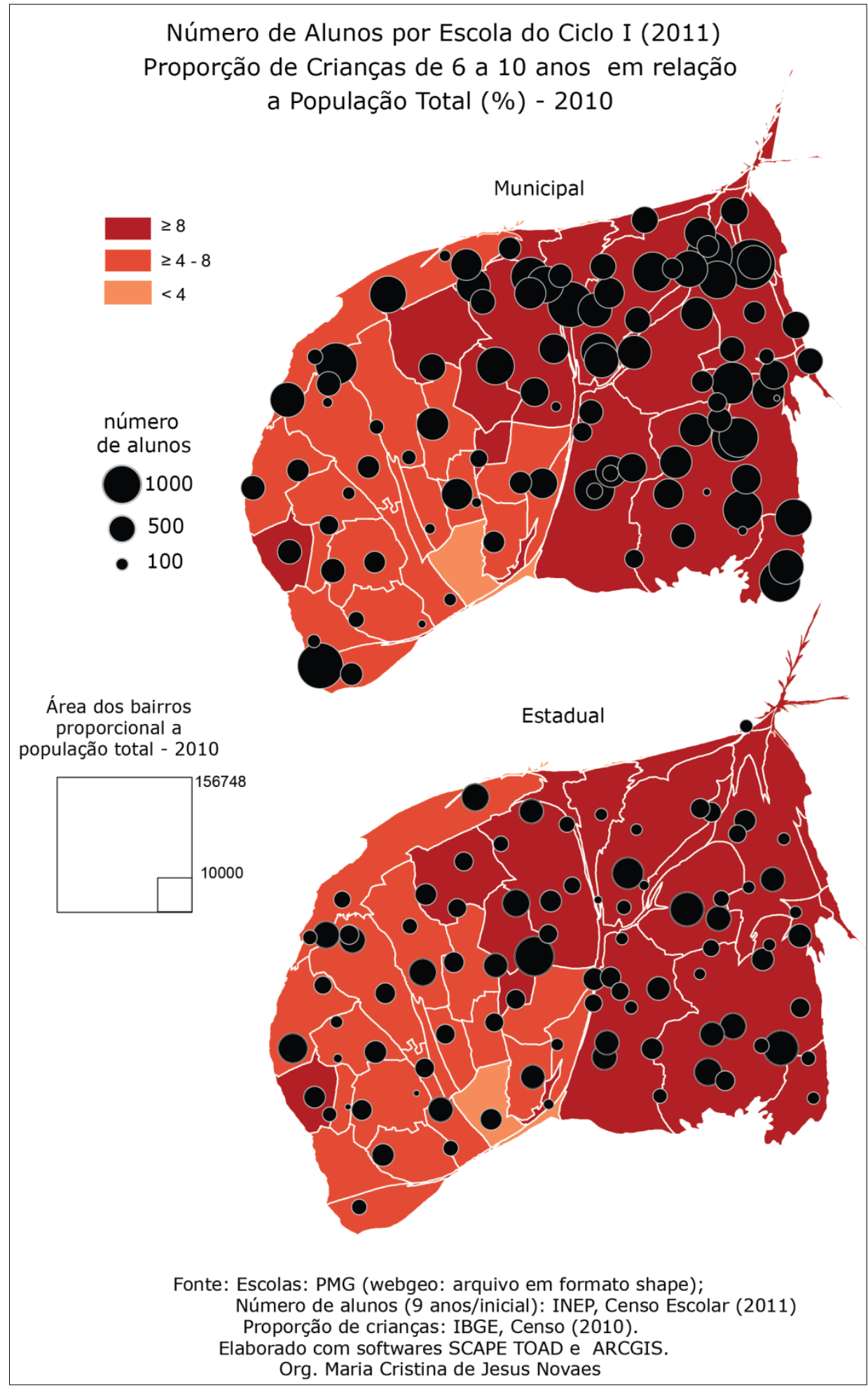

Figura 20 - Número de alunos por escolas do ciclo I e proporção de crianças com 6 e 10 anos - Guarulhos. 
entretanto, em que condições? Essas unidades escolares compartilham o território com inúmeras outras carências como se discutirá e como construir conhecimento escolar em situações tão adversas?

Para o Ensino Fundamental do Ciclo II, atendido apenas pela Rede Estadual, a Figura 21 mostra que as escolas distribuídas por toda cidade, abrigam menor número de alunos, naquelas próximas ao Centro, em que parte da demanda é atendida pelas escolas particulares e a proporção de crianças e adolescentes é entre 3 e $6 \%$, que é menor do que a maioria dos bairros do município, em que esse número supera a taxa de $6 \%$.

Como discutido, a questão da superlotação das escolas constitui-se mais um agravante para o ensino. No caso do Ensino Médio, a Figura 21 mostra que poucos bairros têm menos que 4\% de jovens entre 15 e 17 anos, os quais se referem àqueles localizados junto ao Centro e Vila Galvão. A maioria dos bairros da cidade tem índices superiores a $4 \%$ de jovens e as escolas com maior número de alunos distribuem-se por vários bairros do Município.

Na questão da Educação, como mostrado para a Saúde, ainda é difícil qualificar esse atendimento, posto que os indicadores estão mais associados ao acesso, mas tem-se como desafio, qualificar esse serviço acessado. 


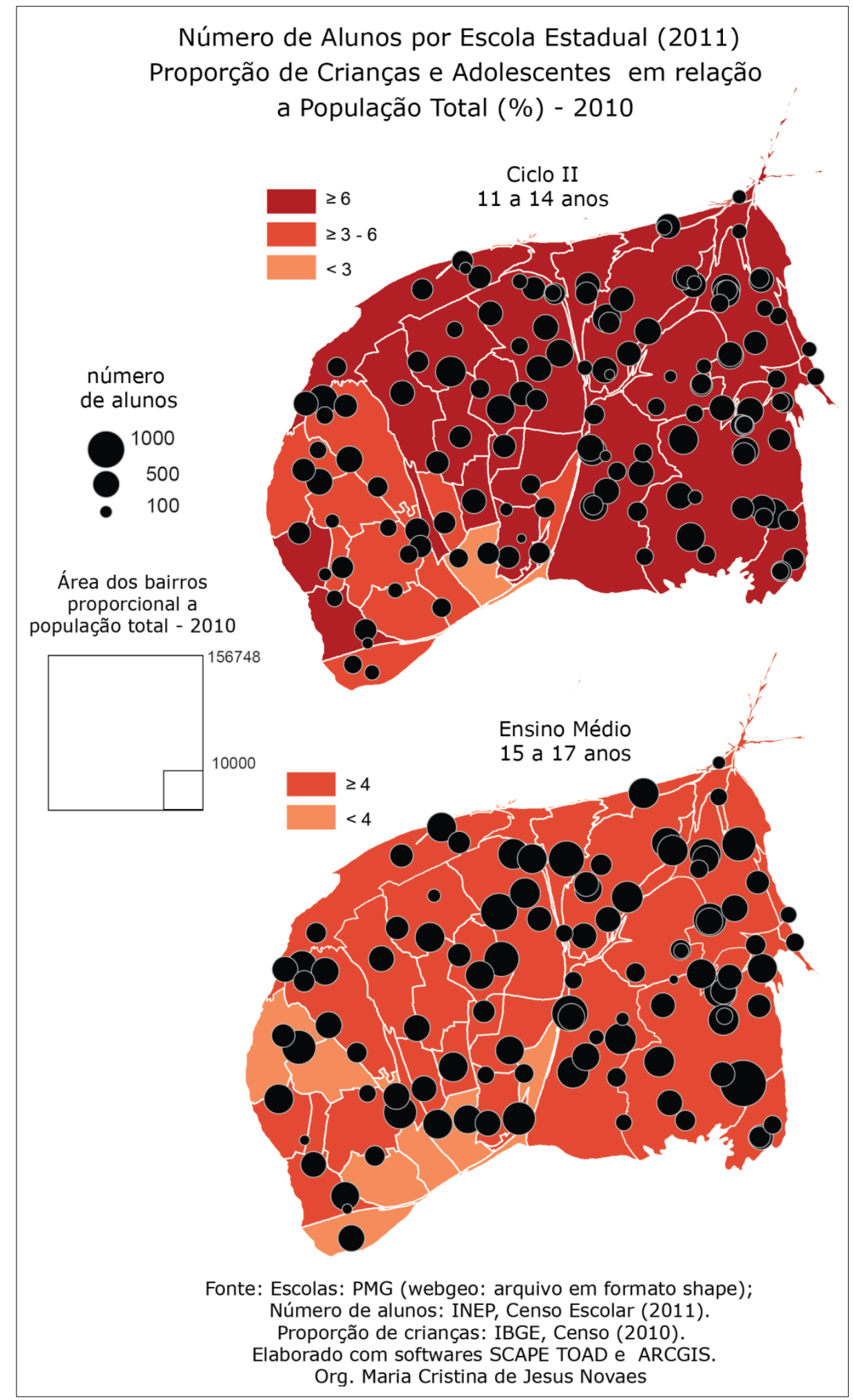

Figura 21 - Número de alunos por escolas estaduais do ciclo II e ensino médio e proporção de crianças e adolescentes - Guarulhos. 


\subsubsection{Moradia, lazer e cultura}

No censo 2010, o município atingiu o número de 360.540 domicílios, que resultou da taxa de crescimento de 24\%, aproximadamente, em relação à década passada. O número de habitantes por domicílio, que era de 3,69 em 2000, caiu para 3,39 em 2010 e, mesmo com essa redução, ainda é maior do que a média da RMSP, onde a taxa foi de 3,23, e que a do Estado de São Paulo, com 3,21 habitantes por domicílio.

A média de moradores por domicílio, de acordo com o bairro, variou entre 2,79 e 3,73, e a Figura 22 mostra a sua distribuição pela cidade. Os índices inferiores a três moradores por domicílio referem-se ao Centro, a alguns bairros do entorno dele e ao Cecap, os quais são circundados por outro conjunto de bairros, em que o número de pessoas variou entre 3 e 3,28. Boa parte dos bairros situados a leste, norte e nordeste do município apresentou taxa entre 3,28 e 3,49, incluindo-se o Jardim Vila Galvão, situado a oeste. Os bairros com maior número de moradores por domicílios, 3,49 a 3,73, associam-se àqueles com maior número de crianças e aglomerados subnormais.

Ao considerar a forma de apropriação dos domicílios do município de Guarulhos, tem-se, conforme a Tabela 12, que 312.931 deles apresentam ordenamento regular, dos quais $70,54 \%$ eram próprios, $21,45 \%$ alugados, $6,60 \%$ cedidos e o restante apresentava outra condição (SEADE, 2010). Com ordenamento irregular, denominado pelo IBGE como aglomerados subnormais, havia 57.563 domicílios, em 2010, que correspondiam a $15,5 \%$ do total, nos quais habitavam 214.885 pessoas, ou seja, $17,5 \%$ do total da Cidade. Ressalta-se que ao somar os domicílios com ordenamento regular e irregular o total é de 370.494, distinto do apontado anteriormente pelo IBGE. 


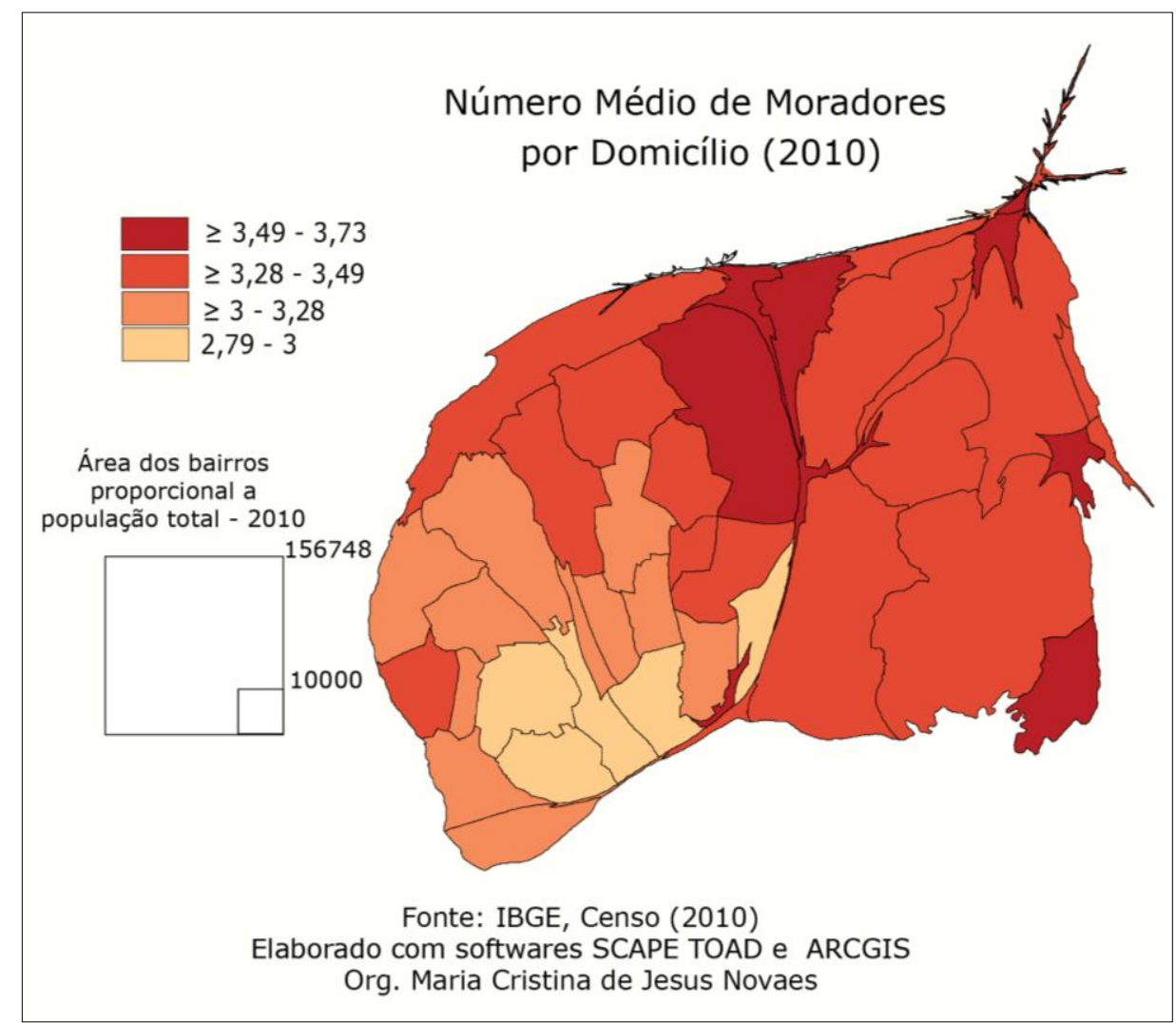

Figura 22 - Número médio de moradores por domicílio - Guarulhos

Tabela 12 - Moradores e Domicílios particulares permanentes, com ordenamento regular, por condição de ocupação, 2010.

\begin{tabular}{|c|c|c|}
\hline Condição de ocupação & (Unidades) & $(\%)$ \\
\hline Total & 312.931 & 100,00 \\
\hline Próprio & 220.755 & 70,54 \\
\hline Alugado & 67.376 & 21,53 \\
\hline Cedido & 20.646 & 6,60 \\
\hline Outra condição & 4.154 & 1,33 \\
\hline
\end{tabular}

Fonte: Seade (2010).

O IBGE classifica como aglomerados subnormais "cada conjunto constituído de, no mínimo, 51 unidades habitacionais carentes, em sua maioria, de serviços públicos essenciais, ocupando ou tendo ocupado, até período recente, terreno de propriedade alheia (pública ou particular) e estando dispostas, em geral, de forma desordenada e densa".

É importante mencionar que ao associar os aglomerados subnormais aos bairros, identifica-se que existem bairros que têm moradias nessa 
condição, no entanto, não foram apontados no levantamento do IBGE, que é o caso do Fortaleza, por exemplo.

Ao resgatar como ocorreu a formação territorial do município, onde, até os anos 60, do século passado, a ocupação se concentrava, principalmente, na porção sudoeste do município, em torno da área central, com núcleos menores como os bairros de Cumbica, Pimentas, Presidente Dutra e Taboão, a autoconstrução, já era a solução para obtenção da casa própria, que se generalizaria nas décadas seguintes, com o grande adensamento populacional.

Conjugados a esse tipo de ocupação, surgem os primeiros núcleos de favelas que, inicialmente, se localizavam próximas ao Centro, geralmente em áreas verdes remanescentes dos loteamentos ou glebas vazias. Em 1970, conforme a Tabela 13, estabeleceu-se a primeira delas e, três anos depois, totalizariam 32 favelas, com 1.386 domicílios, em que moravam 6.930 pessoas.

Tabela 13 - Favelas de Guarulhos

\begin{tabular}{|c|c|c|c|}
\hline Ano & No de favelas & No de domicílios & População \\
\hline 1970 & 01 & 12 & Sem informação \\
\hline 1973 & 32 & 1.386 & 6.930 \\
\hline 1987 & 65 & Sem informação & Sem informação \\
\hline 1989 & 94 & 8.600 & 43.000 \\
\hline 1991 & Sem informação & Sem informação & 52.506 \\
\hline 1993 & 203 & 22.000 & 112.000 \\
\hline 1994 & 218 & 22.500 & 115.000 \\
\hline 1995 & 240 & 26.000 & 130.000 \\
\hline 1996 & 253 & 26.000 & 133.000 \\
\hline 1997 & 289 & 28.200 & 141.000 \\
\hline $1998 / 99$ & 301 & 39.000 & 177.000 \\
\hline 2000 & Sem informação & Sem informação & 163.757 \\
\hline 2002 & 343 & 33.000 & 152.000 \\
\hline
\end{tabular}

Fonte: PMG (2002).

Desde então, de acordo com os dados disponíveis, esse número aumentou continuamente até o ano de 1999, quando abrigavam 177.000 pessoas. Nos dois anos seguintes, essa população mesmo tendo se reduzido, ainda mantinha 152.000 pessoas em 2002, que correspondiam a $15 \%$ da população total. As favelas que se instalavam, normalmente nas 
áreas com restrições ambientais de declividade, cursos de água e vegetação nativa, passaram a conviver com enchentes, escorregamentos e lançamentos de esgotos sem tratamento.

Também merecem destaque as favelas que se instalaram ao longo do sistema viário, em especial na Cidade Industrial Cumbica, em situação bastante precária, parte da qual foi retirada, recentemente, para revitalizar aquele setor industrial.

Atualmente, muitas favelas se aproximam dos 40 anos de existência.

No mapa da Figura 23, foram representados os núcleos de favelas de acordo com a localização no território e nele percebe-se que elas estão disseminadas praticamente por toda cidade. Como o critério adotado pela Prefeitura distingue-se daquele do IBGE, que os define como aglomerados subnormais e abrange diferentes tipos de precariedade, além das favelas, foram organizados os mapas que compõem a Figura 24.

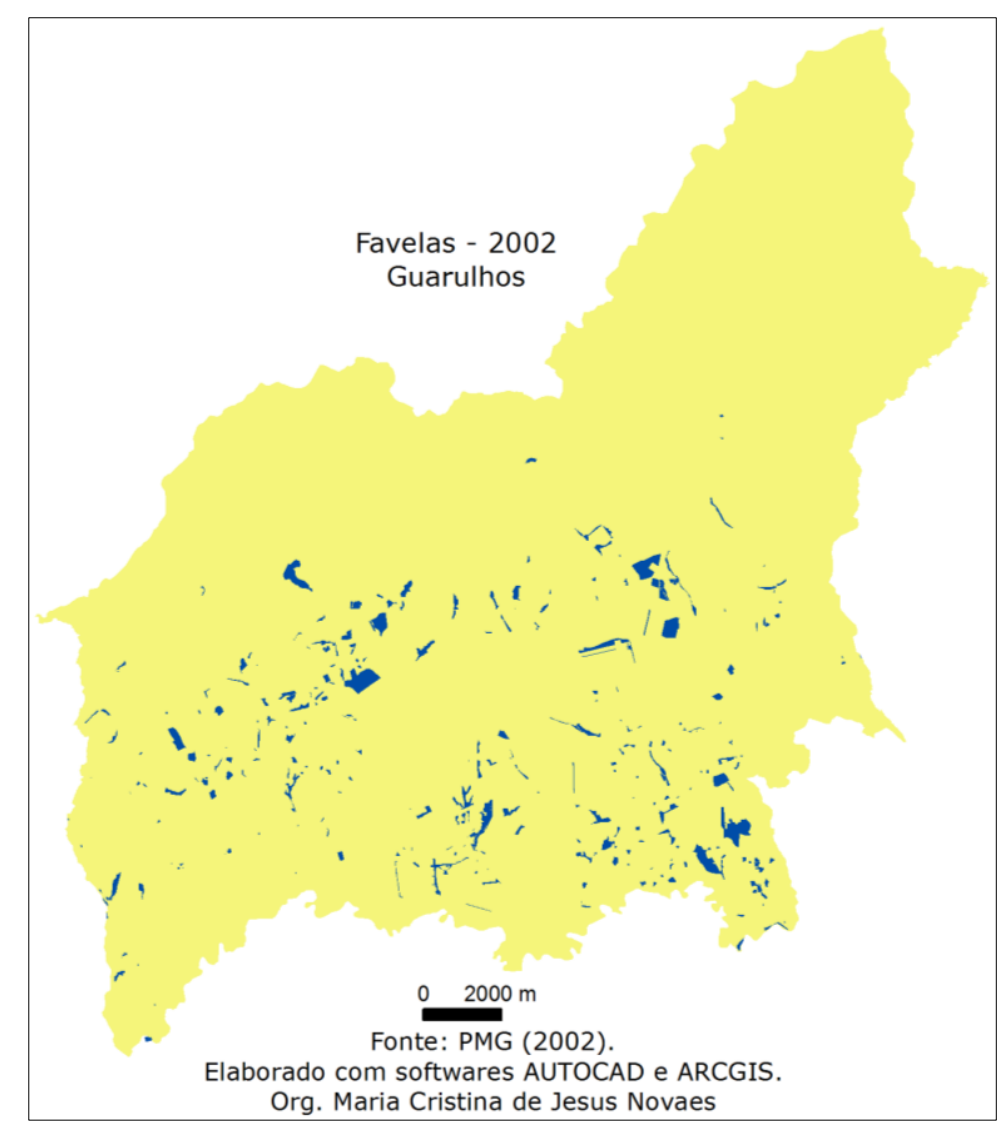

Figura 23 - Favelas segundo a localização territorial. 


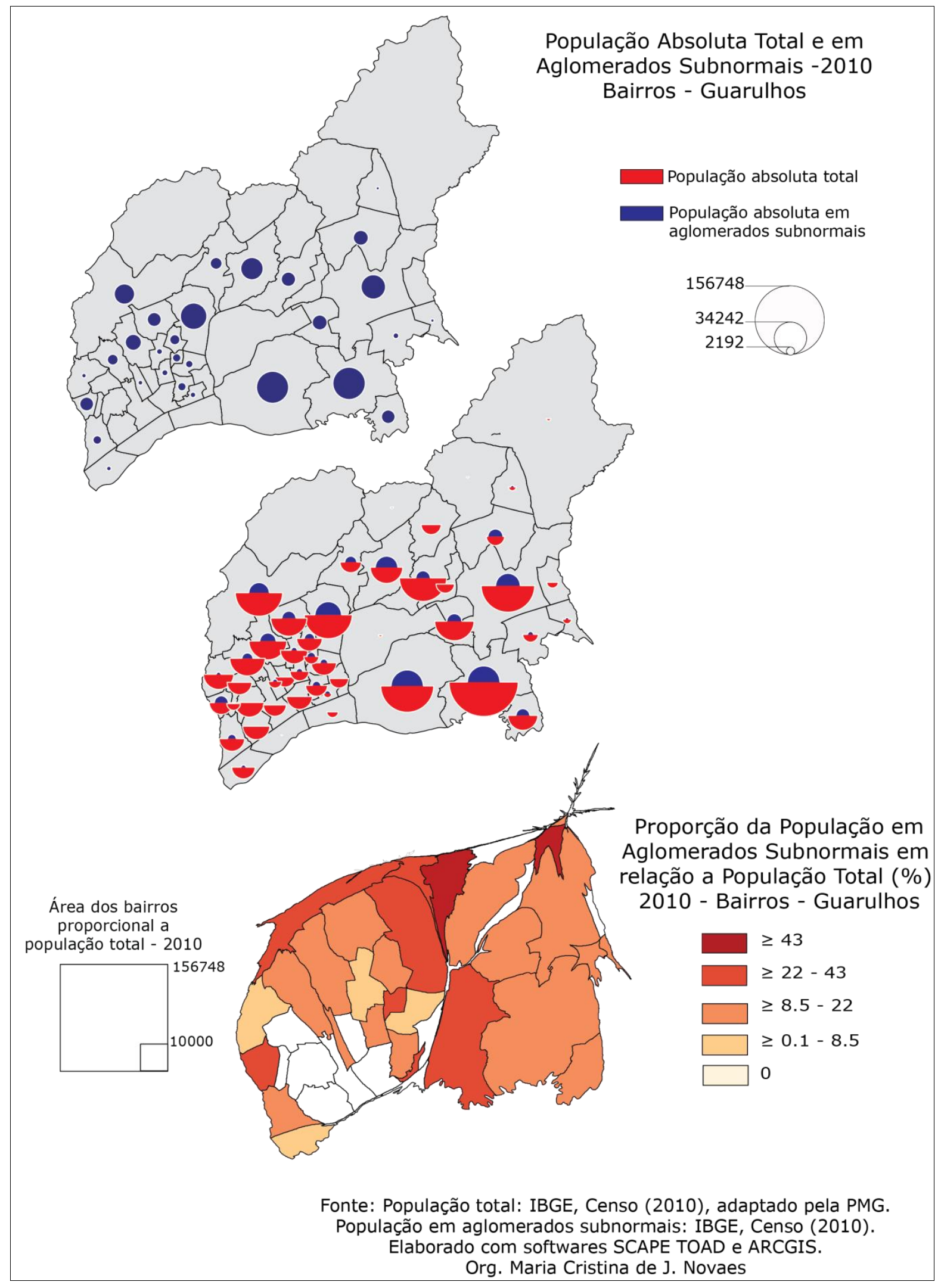

Figura 24 - População absoluta total e população absoluta e relativa em aglomerados subnormais por bairros - Guarulhos. 
A Figura 24, assim como a 23, mostra que a maioria dos bairros apresenta pessoas que habitam em aglomerados subnormais, com destaque para os bairros do leste, nordeste e norte, assim como aqueles situados ao oeste, ao longo da Rodovia Fernão Dias, no Jardim Vila Galvão e Itapegica, os mais antigos. Ao associar a localização desse tipo de moradia e a expansão delas (Tabela 13), percebe-se que esse processo foi intensificado com a instalação do Aeroporto (1985); assim, praticamente todos os bairros vizinhos desse objeto, abrigam moradias com diferentes tipos de precariedade.

Ao considerar a proporção em relação à população total, a anamorfose da Figura 24 revela que, considerando os bairros que apresentam aglomerados subnormais, a maior parte deles tem índice entre 8,5 e $22 \%$, embora em alguns se elevem para taxas que variam entre 22 e $43 \%$ e dois deles, Mato das Cobras e Bananal superam a taxa de $43 \%$. Há, ainda um pequeno conjunto de bairros, que não tem esse tipo de moradia, destacando-se o Centro, bairros vizinhos, o Cecap, Aeroporto e o Lavras. Cabe ressaltar, a interferência direta desse tipo de habitação na qualidade ambiental e na vida das pessoas, mostrado nos indicadores discutidos.

Em suma, em Guarulhos, evidencia-se a pequena participação do Poder Público, em todas as suas esferas, para a questão do provimento da moradia em relação à sua demanda.

Segundo dados da PMG (2011), o Governo Federal construiu, ao todo, 7.471 unidades habitacionais, nos últimos 50 anos, financiados, inicialmente, pelo Banco Nacional de Habitação (BNH) e INOCOOP e, atualmente, por outros programas de habitação, como o Programa de Arrendamento Residencial (PAR), PAT Prossanear e Minha Casa Minha Vida.

O Governo Estadual, desde a década de 70 construiu 10.400 unidades pela Secretaria de Estado da Habitação e CDHU - Companhia de Desenvolvimento Habitacional (PMG, 2011). Entre eles, destaca-se o conjunto habitacional CECAP, que forma um dos bairros do município, 
vizinho a oeste do aeroporto que, normalmente, apresenta os melhores indicadores sociais, se comparado com a grande maioria dos bairros do município.

Além da construção direta de unidades habitacionais, há os investimentos indiretos, realizados por ambas as esferas, em que o Goveno Federal contou com a colaboração em recursos financeiros da Prefeitura de Guarulhos que, desde 2003, criou a Secretaria de Habitação, cuja finalidade específica é coordenar a elaboração e a implementação dos planos e projetos habitacionais, além da regularização fundiária no Município (PMG, op.cit.).

O resultado foi que parte dos munícipes guarulhense, movidos pela necessidade, em ações individuais e coletivas, necessitou forjar a moradia e a própria urbanização local, que redundou, entre outros, na associação de moradias regulares e irregulares, resultantes da ocupação de terrenos públicos e privados, formando as favelas, loteamentos clandestinos e irregulares, carentes de infraestruturas.

No sentido contrário, ou seja, em que a produção da moradia é regularizada, em áreas melhor estruturadas, providas pela atuação do poder público, a cidade vem passando por um intenso processo de verticalização. Até o começo do século atual, os edifícios do município limitavam-se, principalmente, à região central da cidade e à Vila Galvão, que, sobretudo, após 2008, continuou sendo a área preferencial para sua instalação; entretanto, com menos pavimentos, os bairros dos Bonsucesso, Cumbica, São João e Taboão, responderam por $20 \%$ dos alvarás emitidos pela Prefeitura para a construção de novas unidades habitacionais, entre 2007 e 2012; e o bairro dos Pimentas com 14\% dos alvarás (PILOTTO et al, 2012).

De acordo com os alvarás expedidos entre 2007 e 2012 para edificações acima de três pavimentos, foi construído o mapa da Figura 25, que foi obtido a partir de Pilotto et al (op.cit), segundo dados da PMG.

A Figura 25 revela que as edificações entre 3 e 5 pavimentos localizavam-se em vários bairros do Município, entretanto, estavam em 
maior quantidade nos bairros de Bonsucesso e Pimentas. Aquelas que tinham entre 5 e 10 pavimentos situavam-se pontualmente nos bairros de Cumbica, Água Chata e Pimentas, os demais estavam nos bairros da parte oeste de Guarulhos. Os edifícios acima de 10 pavimentos concentravamse na parte oeste do município, sendo mais numerosos aqueles com mais de 15 pavimentos, em que se destacam os bairros de Vila Augusta, Gopouva, Centro e Vila Galvão, com o maior número de empreendimentos.

Os bairros dos Pimentas, Bonsucesso, São João e Taboão, que passaram a receber esses edifícios, principalmente com menos de 5 pavimentos, correspondem às novas centralidades que vêm se formando no município, que conta também com a chegada de outros empreendimentos, ligados às funções produtivas e ao sistema viário. Isso acontece para viabilizar a acessibilidade para essas regiões, destacando a ampliação das rodovias Dutra e Airton Senna; da Ligação Porto Aeroporto a Avenida Jacu-Pêssego, construção de terminais rodoviários; revitalização e expansão do sistema viário local e de saneamento (drenagem, esgotamento sanitário, água e resíduos), estimulados pelo Programa de Aceleração do Crescimento - PAC, do Governo Federal e contrapartida das demais esferas de governo.

O bairro dos Pimentas, principalmente, concentrou novos equipamentos públicos, como um hospital, um campus da Universidade Federal de São Paulo, um Centro de Educação Unificado - CEU e empreendimentos habitacionais para a população relocada, sendo estes dois últimos também implantados em outros bairros. 


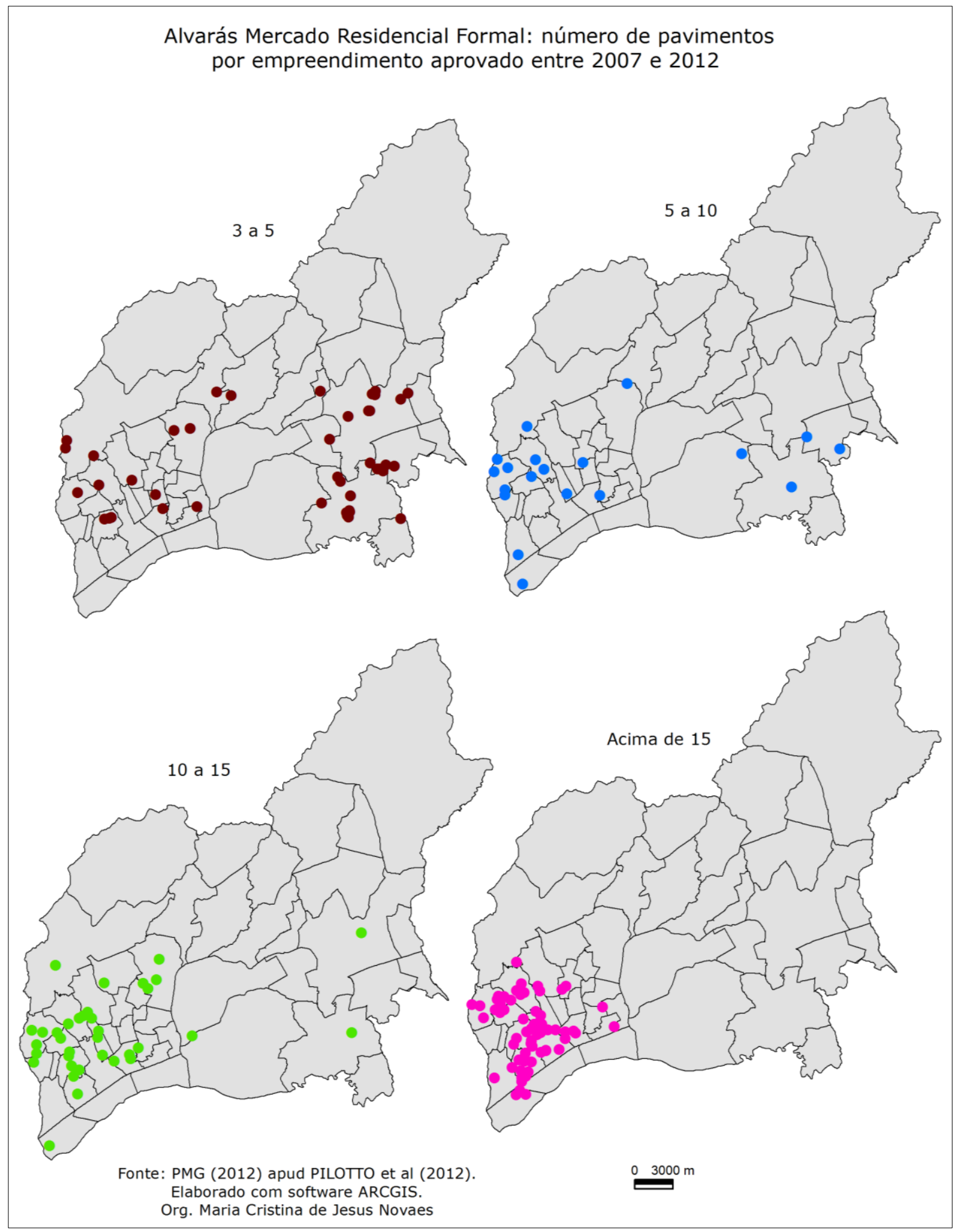

Figura 25 - Alvarás emitidos pela PMG, entre 2007 e 2012, para edificações acima de 3 pavimentos - Guarulhos. 
Diante disso, como revela Maria Adélia Aparecida de Souza (1994), a verticalização resulta da disponibilidade de terrenos grandes, a acessibilidade e o nível de renda da população. No caso de Guarulhos, pequena parte da população local tem usufruído desse processo, em que, principalmente, pessoas vindas da capital paulista têm adquirido os imóveis na cidade, por conta dos custos relativamente menores do que os do município de São Paulo.

A dimensão dos imóveis, conforme pesquisa de campo, levantamentos em jornais, revistas, panfletos e internet, realizados sobre os imóveis que estão sendo construído ou já foram concluídos neste ano (2012), os quais totalizaram 41 edifícios: em 26 deles, a área útil variava entre $36 \mathrm{~m}^{2}$ a $80 \mathrm{~m}^{2}$; os menores localizavam-se, preferencialmente, nos bairros do leste do município; outros 14 tinham área entre 80 e $182 \mathrm{~m}^{2}$, e apenas um tinha área superior a $200 \mathrm{~m}^{2}$.

Esses dados indicam que parte dos novos habitantes de Guarulhos também dependerá dos objetos públicos para suas necessidades educacionais, de saúde, lazer e afins. Assim, questiona-se como ficará o uso desses objetos que já são deficitários para a maioria dos munícipes e a fluidez, que vem cada vez mais se reduzindo, à medida que avança a verticalização, somada ao aumento da frota de veículos, que era de 229.241, em 2002, e chegou ao expressivo número de 443.651, em 2010 (SEADE, IBGE), e a estrutura atual do sistema viário que dificulta sua expansão, principalmente, nas áreas centrais.

Outro agravante promovido pelo processo de verticalização, de acordo com Souza (1994), é que, com ele, há um efeito de sobrevalorização do espaço, que corresponde às áreas melhor equipadas, do ponto de vista da infraestrutura, e vai projetar-se como valor, a partir do crescimento do preço médio por metro quadrado. Com isso, a verticalização, além assegurar plenamente a reprodução, através da combinação de diversas formas de capital (fundiário, produtivo, imobiliário e financeiro), valoriza ou sobrevaloriza o espaço urbano onde se instala (SOUZA, op.cit.). 
No caso de Guarulhos, as desigualdades territoriais entre o centro e as áreas periféricas acentuam-se com a verticalização, além de expandilas para o espaço interno envolvido nas novas centralidades, de que, no caso, boa parte dos habitantes, que nesse momento poderia usufruir das relativas melhorias, acaba tendo que procurar novas moradias, por conta da sobrevalorização das áreas que habitavam.

Espera-se que as novas centralidades, importantes por diminuírem a necessidade de mobilidade dos munícipes até a centralidade principal, agreguem ao território objetos sociais, como hospitais, teatros, museus entre outros, considerando o adensamento populacional. No caso do bairro dos Pimentas, que recebeu recentemente esses tipos de objetos, é um dos bairros que mais crescem na cidade, precisando ser bastante ampliado. Há, ainda, a questão da qualidade, em que, por exemplo, o campus da Universidade Federal, funciona de modo precário, que dificulta em muito as condições de ensino-aprendizado, já comentado.

Além da acessibilidade, outro atrativo são os objetos ligados ao consumo, como shopping centers e hipermecados, parques municipais, hospitais, escolas, entre outros.

Os parques municipais, segundo PMG, em 2008, totalizavam 15 e sua distribuição, mostrados na Figura 26. Ao observar a distribuição deles, percebe-se que, com exceção de apenas um, situado no bairro dos Pimentas, o restante está concentrado na parte oeste da cidade, dentre eles destacando-se o Bosque Maia (Bairro do Maia).

Entre os objetos ligados à cultura e lazer, há os cinemas, que obrigam as pessoas que querem acessá-los a frequentarem os shopping centers, pois é lá que estão localizados, tanto no Internacional na parte oeste, como no de Bonsucesso na parte leste. Na Figura 27, visualizam-se os equipamentos públicos principais ligados à cultura.

As bibliotecas são ao todo 13, geridas pela Prefeitura, concentradas principalmente junto aos bairros centrais, mas também distribuídas por bairros da parte leste e nordeste. Duas das bibliotecas fazem parte dos dois grandes centros educacionais (um no Macedo e outro nos Pimentas), 
que abrigam outros equipamentos e foram recentemente construídos. Os museus são três, um na Vila Galvão de História Natural, outro no Centro, onde funciona o Arquivo Histórico e no Aeroporto com o da aeronáutica, ainda incipiente.

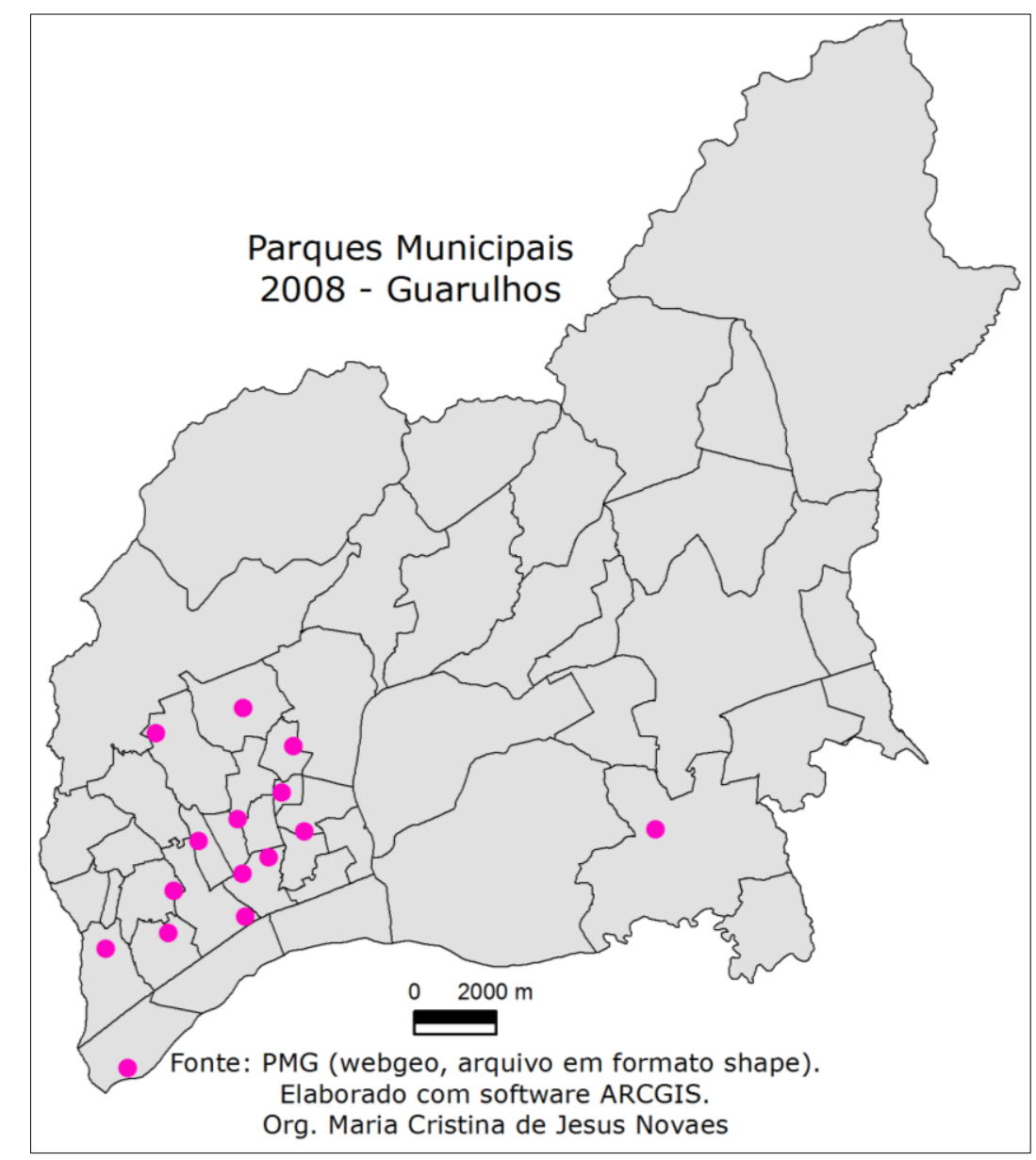

Figura 26 - Parques municipais - Guarulhos.

A cidade conta com cinco teatros, três construídos recentemente, localizados no São João, Pimentas, na parte leste, e Macedo, na parte oeste, sendo que os dois últimos estão integrados aos Centros Educacionais. Os outros dois, mais antigos, na parte oeste, ficam na Vila Galvão e Tranquilidade, ocupando um antigo cinema tombado, do complexo hospitalar Padre Bento, e foi recuperado para essa nova função. Observa-se a carência de equipamentos desse tipo por todo Município, que é levemente melhor para alguns bairros do oeste. 


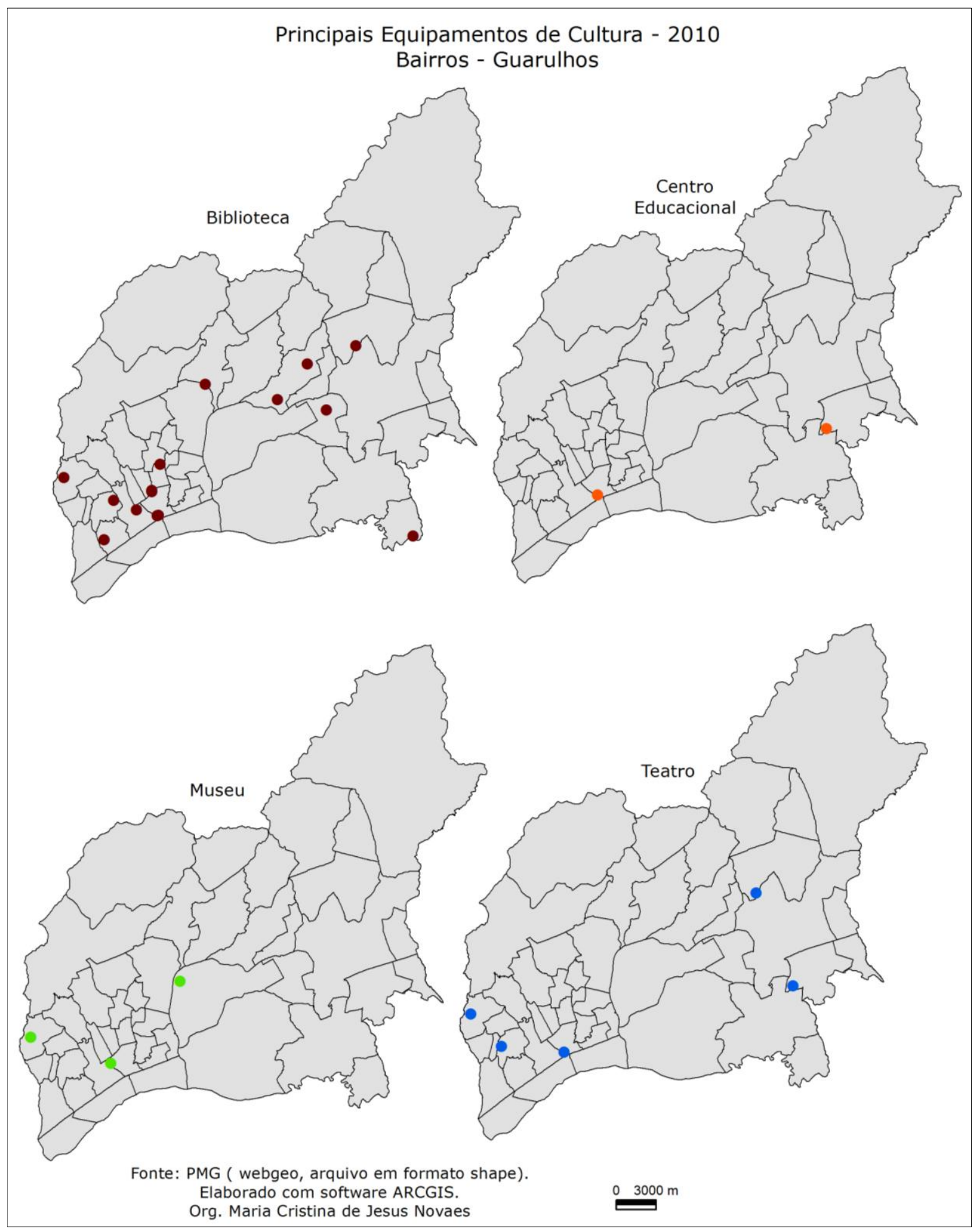

Figura 27 - Principais equipamentos de cultura - Guarulhos. 
Com relação ao rendimento mensal por domicílio, organizou-se a coleção de mapas que compõem a Figura 28. Nela percebe-se que a maior parte dos domicílios do Município tem média de rendimento entre dois e cinco salários mínimos, com taxa superior a 35\%, menos significativa nos bairros junto ao Centro, com índices entre 15 e 35\%, e com 25\% a 35\% dos domicílios com rendimento entre cinco e dez salários mínimos.

Nos bairros mais centrais, localizam-se os domicílios com os maiores rendimentos, destacando-se o Maia (abrigando de 15 a 25\% famílias com mais de vinte salários mínimos), seguido do Centro, Macedo, Vila Galvão, Vila Augusta, Cecap e Aeroporto, na maioria dos quais, se situam também as menores taxas de domicílios sem rendimento, um número menor que 5\%. Esses são mais numerosos em parte dos bairros do norte e oeste e em praticamente todos os bairros do leste e nordeste, em que as taxas sem rendimentos variaram entre 5 e 15\%, e correspondem, em sua maioria, aos que também concentram maior número de domicílios com rendimentos inferiores a dois salários.

Outro fator relevante na formação socioespacial brasileira é a distribuição desigual pelo território, das pessoas em função da cor da pele, fato observado também em Guarulhos, conforme Figura 29. A população com cor da pele amarela é mais expressiva no Centro, em que a taxa fica entre 5 e 20\%, sendo nos demais bairros inferior a 5\%. As pessoas que se declararam como pretas, na maioria dos bairros, contam entre 5 e 20\%, as mesmas que, em conjunto de bairros junto ao Centro, Vila Galvão e Cecap, correspondem a menos de $5 \%$.

A proporção de pessoas brancas é maior nos bairros da parte oeste, superando $60 \%$, e correspondendo a uma porcentagem entre 40 e 60\% nos demais bairros, a mesma da população parda, para parte desses bairros. No caso dos bairros junto ao Centro, as pessoas pardas correspondem a taxas entre 5 e 20\%. Assim, a distribuição por cor da pele mostra que as áreas que usufruem das melhores condições territoriais, são habitadas principalmente por pessoas brancas. 


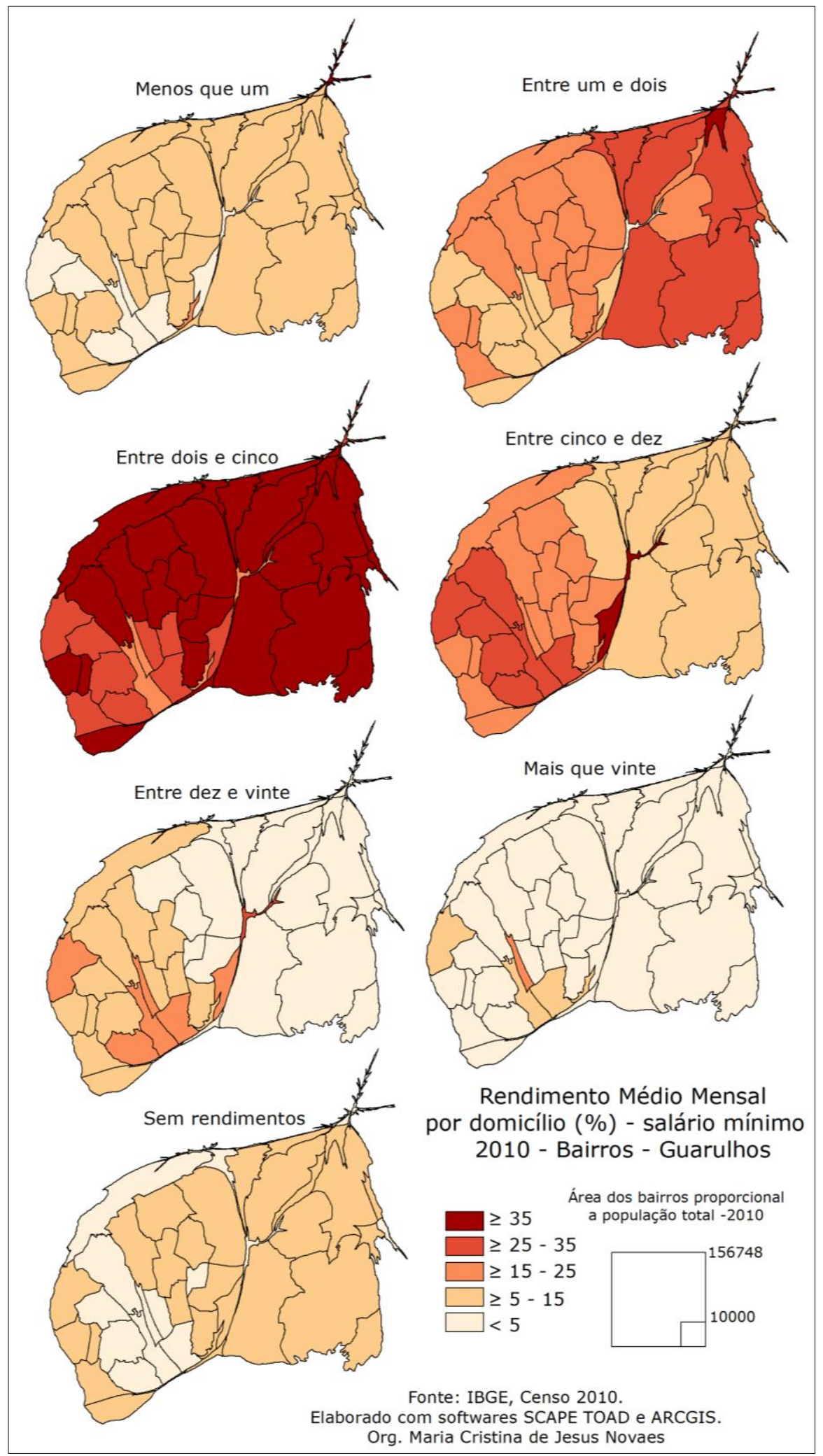

Figura 28 - Rendimento médio mensal por domicílio - Guarulhos. 


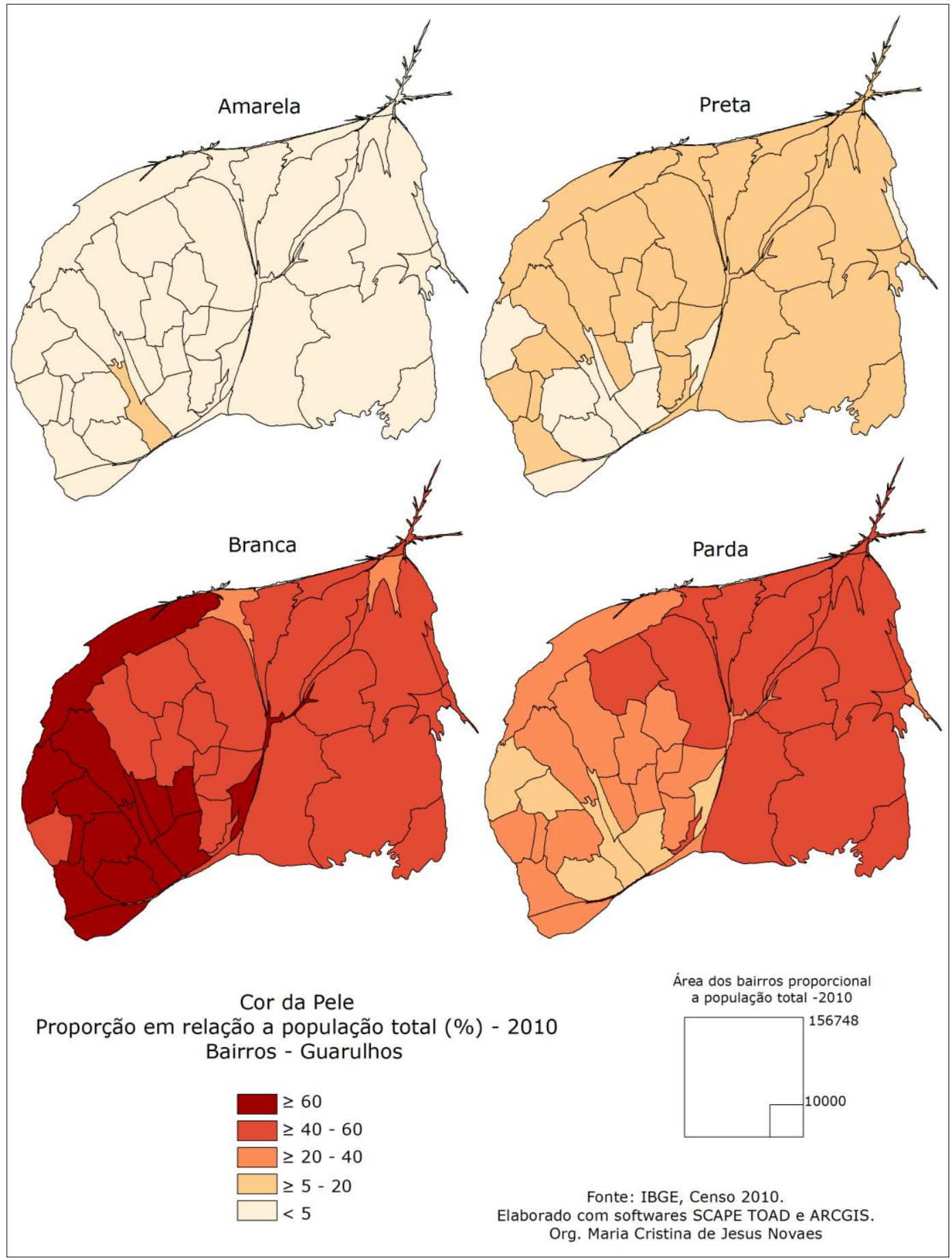

Figura 29 - Proporção da população em função da cor da pele Guarulhos. 
A partir dessa discussão envolvendo os objetos sociais e indicadores relevantes, o próximo subitem versa sobre a associação deles com o meio técnico-científico informacional.

\subsubsection{Meio técnico-científico-informacional e a segregação socioespacial}

O aporte diferenciado de objetos com maior conteúdo de ciência, técnica e informação acentua o processo de segregação socioespacial, devido à formação de subespaços luminosos - maior concentração de objetos hegemônicos - em oposição aos subespaços opacos. Esses espaços opacos, dominantes no interior da cidade, são marcados pelos tempos lentos, adaptados às infraestruturas incompletas herdadas do passado, que se configuram como zonas de resistência, nas quais a economia não hegemônica e as classes sociais hegemonizadas encontram suas condições de sobrevivência (SANTOS,1994b, 1997).

O sistema de ações que movimentam os objetos hegemônicos faz com que o espaço produtivo seja preponderante sobre o espaço de todos. No caso, o domínio é dado pelo sistema de circulação, que preside a produção, posto que não basta produzir, é preciso colocar a produção em movimento (SANTOS, 1997). Para o autor,

[...] Uma das características do mundo atual é a exigência de fluidez para a circulação de ideias, mensagens, produtos ou dinheiro, interessando aos atores hegemônicos. A fluidez contemporânea é baseada nas redes técnicas, que são um dos suportes da competitividade. Daí a busca voraz de ainda mais fluidez, levando à procura de novas técnicas ainda mais eficazes. A fluidez é, ao mesmo tempo, uma causa, uma condição e um resultado. (SANTOS, op.cit., p. 218).

Completa o autor que a fluidez "não é uma categoria técnica, mas uma entidade sociotécnica. Ela não alcançaria as consequências atuais, 
se, ao lado das novas inovações técnicas, não estivessem operando novas normas de ação" (SANTOS, op. cit., p. 219). Os fluxos são mais intensivos, extensivos e seletivos e há, pela economia dominante, uma busca desatinada por fluidez e aqueles que conseguem sobreviver a um mundo marcado pela inovação galopante e uma concorrência selvagem, são os mais velozes (SANTOS, op.cit.).

Dessa forma, verifica-se que o que vem sendo planejado ou já está em execução prioriza o sistema de circulação, a partir de diversos sistemas de engenharia, destacando-se aqueles que integram a RMSP e Macrometrópole Paulista ao subsistema presente em Guarulhos: as Rodovias Dutra, Fernão Dias e Ayrton Senna, o Aeroporto Internacional e o futuro trecho norte do Rodoanel, todos com concessão privada.

Para o trecho norte do Rodoanel, é proposta conectividade com as Rodovias Dutra, Fernão Dias e o Aeroporto Internacional de Cumbica, por acesso próprio. Ele circundará em sentido leste-oeste a cidade, ao sul da porção com mais vegetação nativa e Parques Cantareira, Serra de Itaberaba e Casa da Candinha. Seu traçado conjugado a outros nodais é mostrado na Figura 30.

A futura ampliação da Avenida Jacu Pêssego pretende incrementar a integração com a zona leste de São Paulo, região do Grande $A B C$ e a ligação com o Porto de Santos, importante ao transporte de cargas.

São previstos, ainda, o Expresso Aeroporto e o Trem Metropolitano que vão fazer a ligação do Aeroporto à Luz, ambos com o mesmo traçado, em que o Expresso tem apenas uma parada no Aeroporto e o trem uma estação no Cecap, vizinho ao Aeroporto. $\mathrm{Na}$ região do entorno do Aeroporto foi construída a Rodoviária e, em fase de instalação (2012), encontra-se o Corredor Tucuruvi-Taboão e seus terminais. Está previsto também o Corredor de São Mateus/SP, ao Cecap.

Os sistemas em implantação contam com investimentos das esferas públicas municipal, estadual e federal, além de aportes financeiros de organismos internacionais naqueles mais complexos. 


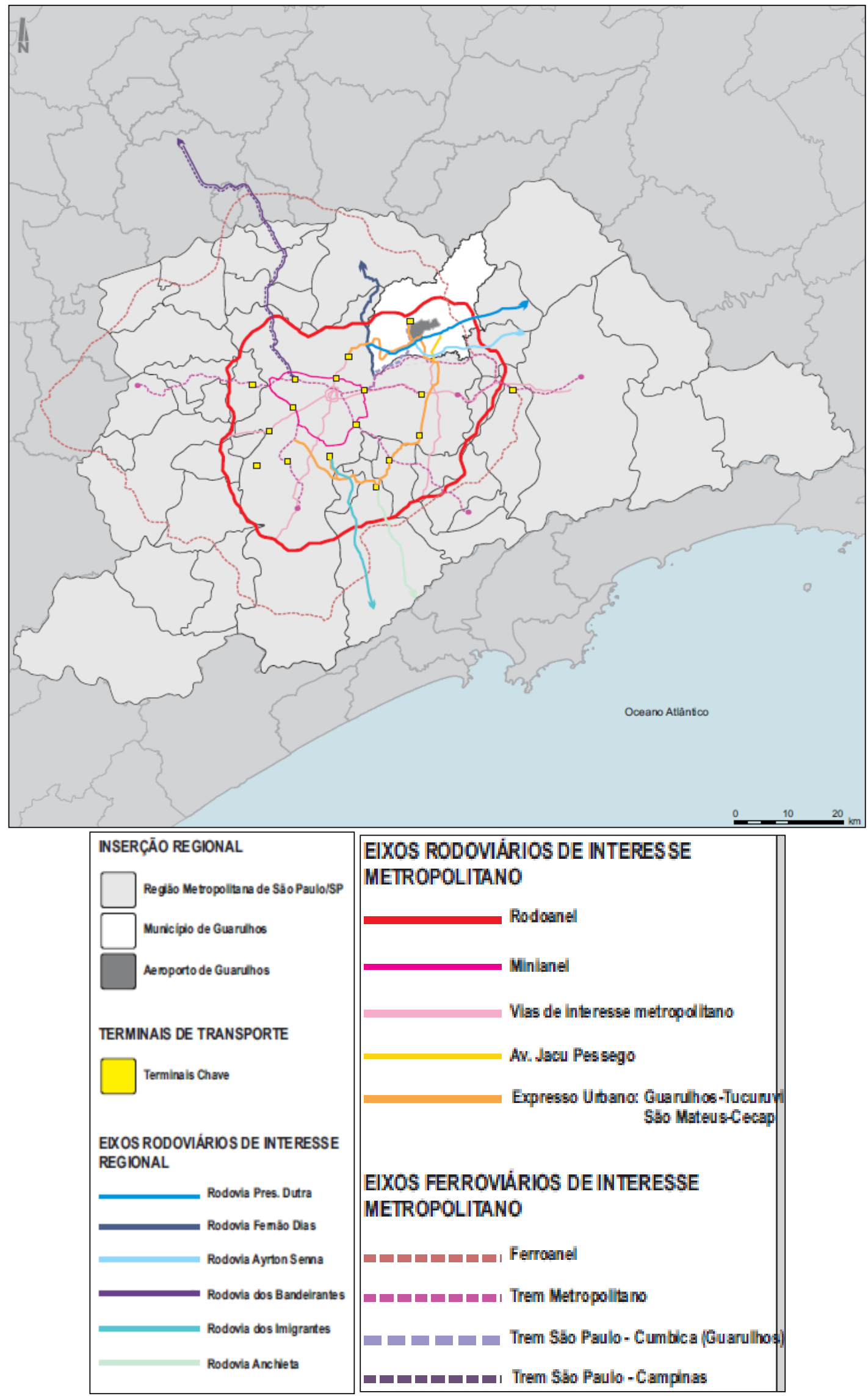

Figura 30 - Sistema de Circulação principal existente e projetado na RMSP. Fonte: PILOTTO et al (2012) elaborado a partir do Plano Integrado de Transporte Urbano 2025 (STM/SP, 2006). 
O Rodoanel mostra parte da problemática que se associa a esse sistema de engenharia, entre eles a questão das finanças, pois constitui uma obra de alto valor econômico, resultante da associação do poder público e instituições financeiras internacionais; diz respeito à questão ambiental uma vez que o traçado dele atravessa as áreas de preservação natural, e à questão social pela desapropriação de áreas habitacionais e parte dos habitantes, que questiona, entre outros problemas, a perda da qualidade de vida.

De acordo com Silveira (2008), a implantação da modernidade na metrópole significa um peso para os demais aspectos da vida local, mediante custos públicos e privados. Tais adaptações ao moderno representam lógicas distantes, que incidem sobre subespaços privilegiados do organismo urbano, mas cujo custo é verdadeiramente social. Em Guarulhos, essa disparidade se acentua, quando se compara a riqueza produzida e os indicadores sociais dela resultantes.

Nesse sentido, esses objetos modernos são construídos por grandes investimentos do Estado, socializando os custos, mas quem acaba operando é a iniciativa privada. Como mostra, Silveira (op.cit.) constituem um exemplo de violência estrutural, que amplia as outras modalidades de violências noticiadas. Exemplo emblemático foi a chegada do Aeroporto, que hoje é rodeado por bairros em que a existência das pessoas é marcada por diferentes carências.

Em oposição aos subespaços fluidos, a maioria da população convive com a fluidez limitada, observada pela precariedade, do ponto de vista quantitativo e qualitativo, dos meios de transportes coletivos. Tal situação tem se agravado pela expansão da verticalização e com a intensificação do trânsito nos últimos anos, associado ao sistema viário incompatível perante o fluxo imposto, principalmente nos bairros mais centrais. Somase a inexistência de transporte de massa que, como destacado, foi extinto.

Segundo Santos (1994a, 2009a), a combinação de dispersão e de concentração é o que configura o espaço da metrópole contemporânea, correlacionada ao território Guarulhense. A concentração, causada pelo 
processo de renovação urbana, ocorre de várias formas, entre elas a partir da verticalização, da substituição de autoconstrução por duas ou mais casas planejadas no mesmo lote, pela refuncionalização dos espaços, como no caso das áreas centrais, em que a função residencial é substituída pela comercial ou de serviços e nos bairros mais populosos, principalmente, que mantêm elevado incremento populacional, superior a $8 \%$ na última década.

A dispersão perpetua-se, como apontado, pelo processo de espraiamento, que foi bastante agressivo nos anos 80 e 90 e, atualmente, pelos aportes de infraestruturas, como o Rodoanel, e pelas mudanças ora operantes no zoneamento, com a expansão das áreas mistas. Vale ressaltar que essas mudanças no zoneamento têm ocorrido de forma pontual e centralizada, feitas pelo Executivo municipal, sem estudos técnicos específicos previstos no Estatuto da Cidade e com ausência de consulta pública e aos conselhos. As alterações concentram-se na ampliação do gabarito construtivo em vias e glebas nas áreas mais urbanizadas, e também nas mudanças de usos rurais e de proteção ambiental para urbano misto, que culminaram em ações civis junto à Promotoria Pública, para conter tais mudanças.

O meio técnico-científico-informacional, principalmente, pelos objetos hegemônicos, agrava o processo de segregação entre os bairros, visto que, como apontado, é privilegiado na produção. Nesse sentido, por exemplo, o processo de verticalização tem como um dos atrativos o sistema de circulação, inclusive o Rodoanel, ainda a ser implantado. Esses fatores conjugados à questão da acessibilidade aos equipamentos sociais públicos e privados, acarretam uma valorização dos espaços e uma consequente redistribuição da população, segundo seus níveis de renda, assim contribuindo, por meio do espaço produzido, na distribuição seletiva da sociedade. Como essas áreas passam a ser ocupadas por classes mais abastadas, a modernização do espaço se impõe, para atender ao novo público (BALBIM, 1996). 


\subsubsection{Segregação socioespacial}

Para sintetizar o entendimento sobre Guarulhos, recorre-se a Souza (2006, pg.172), que registra que "O lugar no mundo de hoje parece ser revelador de uma brutalidade, para todos, sendo uns mais expostos às perversidades dos lugares do que os outros". Tal constatação se aplica ao Município, em que as carências são generalizadas, principalmente aquelas vinculadas à saúde, à Educação, à mobilidade, ao lazer e à moradia, atingindo número representativo de habitantes. Entretanto, considerando o sistema de circulação hegemônico, as áreas em processo de verticalização, a acessibilidade aos equipamentos públicos e os indicadores ligados à Saúde, Educação, Moradia e Lazer, identificaram-se bairros que usufruem de melhores condições perante o total de bairros.

Foram relevantes para a identificação das melhores condições dos bairros as faixas de rendimento médio mensal por domicílio, a maior proporção de idosos, os menores índices de moradores por domicílio, a presença de hospitais, a ausência de pessoas em aglomerados subnormais, a existência de parques municipais e equipamentos ligados à cultura, os alvarás expedidos pela Prefeitura para empreendimentos com mais de 10 pavimentos, visto que são os mais valorizados.

As unidades básicas de saúde e unidades escolares voltadas ao ensino fundamental não foram consideradas como componentes para delimitação das áreas segregadas, porque o acesso a esses objetos está presente nos bairros. Nesse sentido, os indicadores apontados sobre esses objetos mostram desigualdades no acesso, mas, que necessitariam ser aprofundados para contribuir na análise. Cabe ressaltar, que entre os níveis de ensino em que não há obrigatoriedade, as maiores carências concentram-se no ensino infantil, especialmente creches públicas, que inexistem em parte dos bairros ou são insuficientes perante a necessidade da população.

Como as melhores condições, normalmente, não dizem respeito ao bairro como totalidade, foi feito um modelo que compõe a Figura $31 \mathrm{em}$ 
que os bairros, em geral, são mostrados apenas parcialmente. Os bairros que apresentaram os melhores indicadores foram o Centro, o Macedo, Maia, Cecap, Vila Augusta, Vila Galvão, Torres Tibagi, Paraventi, Gopoúva e Aeroporto, completados com o sistema de circulação dominante formado pelas rodovias e Aeroporto.

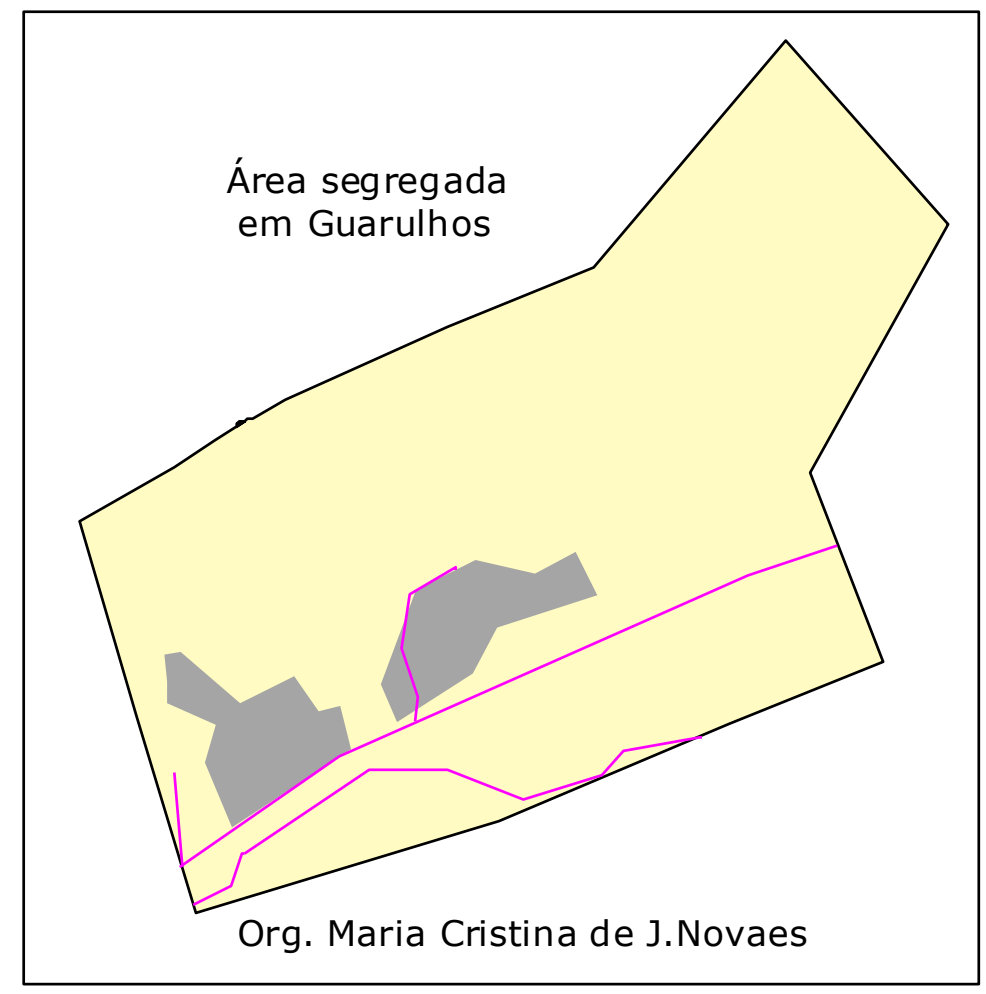

Figura 31 - Área segregada que concentra relativamente as melhores condições territoriais - Guarulhos.

Em oposição, há os bairros periféricos, com os indicadores mais precários e alta densidade populacional, em franco processo de adensamento, potencializado pela migração imposta pelos bairros com indicadores melhores. Esses subespaços em que a demanda amplia as carências preexistentes, tem como agravante a falta de investimentos, pois o direcionamento de recursos, em especial em infraestruturas, não foram planejados nesse contexto. 
Assim, a maior parte do território não é instrumentalizada pelos gestores públicos para assegurar bens e serviços públicos indispensáveis aos seus habitantes.

Então, a partir da segregação socioespacial discute-se a associação com a distribuição dos homicídios.

\subsubsection{A segregação socioespacial e a distribuição dos homicídios}

A natureza e a forma de agrupamento das estatísticas sobre os homicídios constituem uma das dificuldades para o seu estudo. Para ilustrar, uma das discrepâncias resulta, por exemplo, da forma com que as instituições governamentais publicam seus dados. No caso de São Paulo, a Secretaria Estadual de Segurança Pública, classifica o crime de morte fragmentando-o em várias categorias entre elas homicídio doloso ou intencional, e o culposo, quando não há intenção de matar.

Já o Ministério da Saúde, por meio do DATASUS, incorpora-os aos óbitos por agressões que, além dos homicídios dolosos, inclui outras formas de mortalidade, que têm como característica a presença de uma agressão intencional de terceiros, que se utilizam de qualquer meio para provocar danos, lesões ou mesmo a morte da vítima. Nesse sentido, os estudos foram construídos a partir da correlação de várias fontes de dados, que dificultam o entendimento sobre as especificidades, embora num contexto geral, contribuam para a fundamentação das análises da violência.

Ao analisar a taxa de homicídios em geral, para cada 100.000 pessoas - parâmetro internacional - no Brasil, em 1980 verifica-se que ela era de 11,7 e, 30 anos depois, em 2010, chegou a 26,2, sendo de 28,9 o maior número nesse período, registrado no ano de 2003. As regiões metropolitanas tiveram participação importante nessa ascensão, sobretudo, as áreas periféricas das grandes cidades; após décadas de 
convívio com o crescimento praticamente contínuo desse tipo de crime, a RMSP, por exemplo, recentemente passou a observar uma oscilação negativa (WAISELFISZ, 2012).

Em Guarulhos, nesse contexto, considerando a taxa de homicídios dolosos entre 1999 e 2011, reunidos no Gráfico 08, observa-se que era de 58,03 , em 1999, quando sofreu uma pequena queda até 2001 , voltando a subir no ano seguinte; a partir de 2002, diminuiu continuamente até 2010, quando chegou a 13,42, voltando, porém, a subir para 16,03 em 2011. Em relação à RMSP e ESP, Guarulhos mantém-se acima da média de ambos os recortes espaciais.

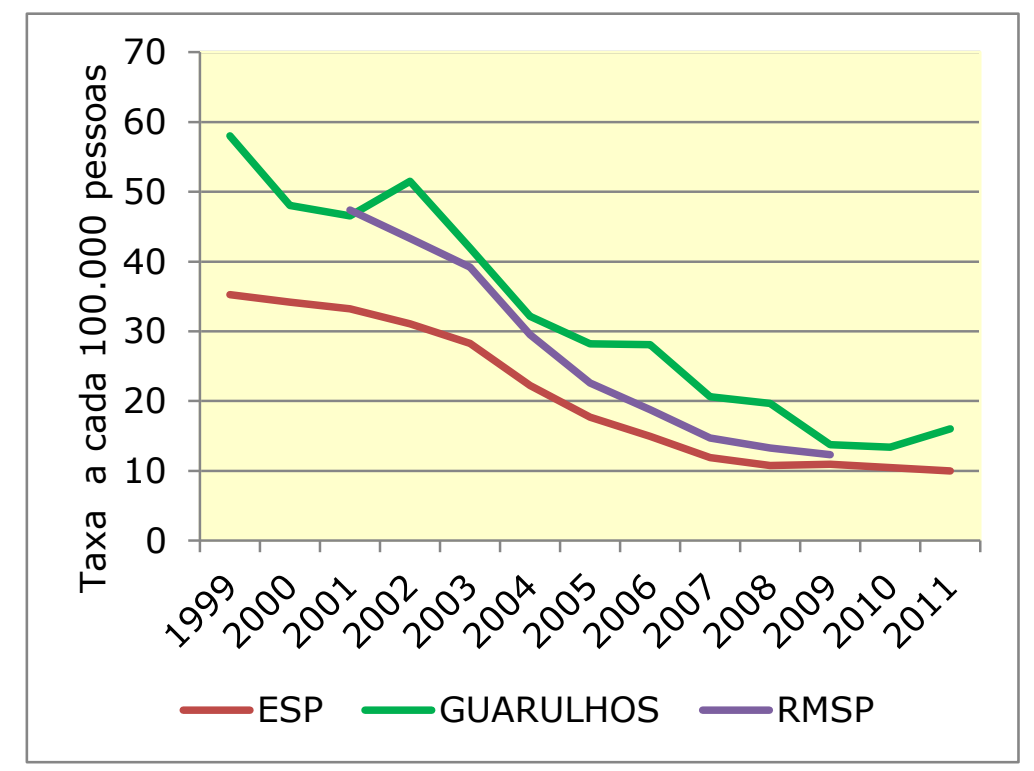

Gráfico 08 - Homicídios dolosos em Guarulhos, RMSP e ESP. Fonte: Secretaria de Segurança Pública do Estado de São Paulo.

Buscando associar o desempenho do número de homicídios com a formação territorial de Guarulhos, como não havia dados disponibilizados especificamente sobre os dolosos para um período mais abrangente, adotou-se 0 indicador que mostra a mortalidade por agressões, apresentado pelo SEADE, com base nos dados da Secretaria Estadual de Saúde, apresentados no Gráfico 09. 


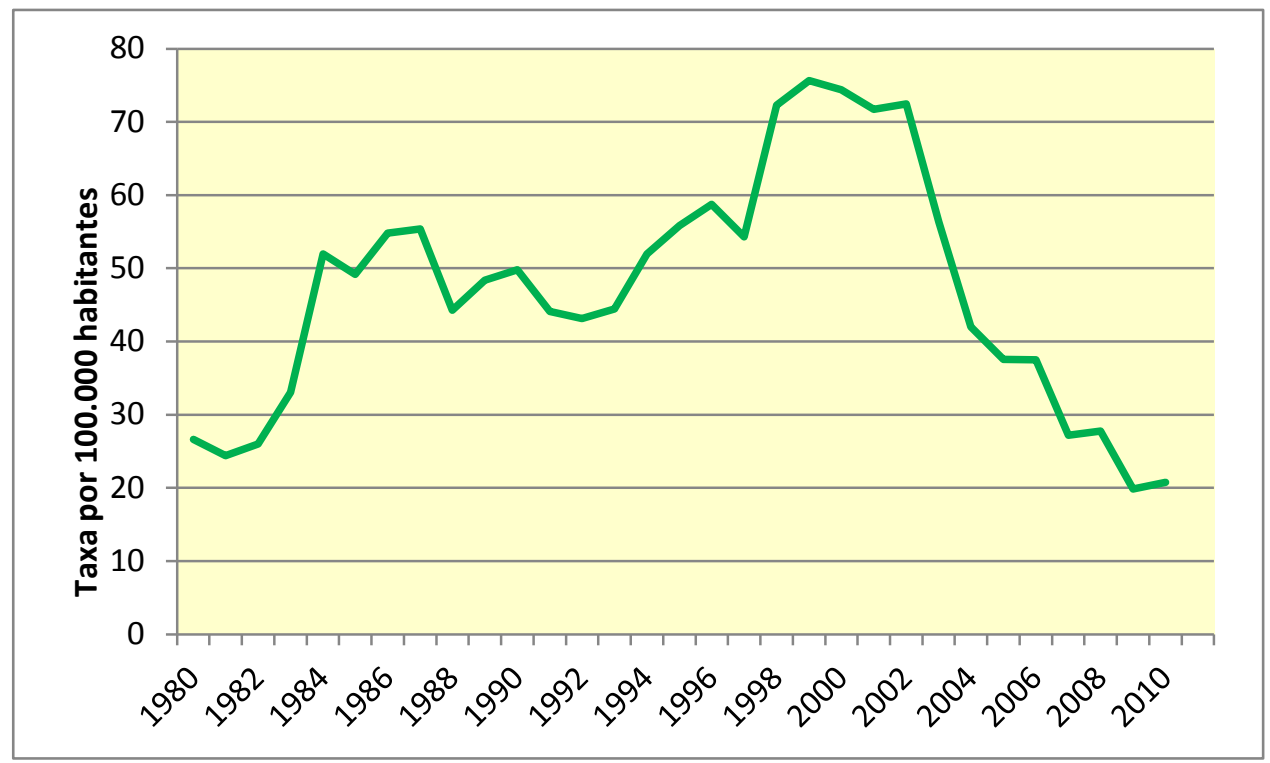

Gráfico 09 - Mortes por agressão em Guarulhos. (SEADE).

Complementando a análise, o gráfico 09 mostra o crescimento desse tipo de ocorrência desde os anos 80, e que foi mais expressivo entre 1998 e 2002, chegando ao ápice em 1999, quando atingiu 75,62. Tal desempenho se associa à constatação de Santos (1994a), segundo a qual a cidade, onde tantas necessidades emergentes não podem ter resposta, está fadada a ser tanto o teatro de conflitos crescentes, como lugar geográfico e político da possibilidade de soluções. Como mostrado com base na formação territorial de Guarulhos, sobretudo, desde meados da década de 1970, multiplicaram-se as diferentes carências sociais e territoriais, somadas às crises econômicas vivenciadas no país, em especial entre os anos 1980 e 2000, em cujo contexto, os homicídios também atingiram os seus maiores números.

Os estudos sobre os homicídios mostram, além das desigualdades na distribuição pelo território, que o grupo mais atingido é formado por adolescentes e adultos, do sexo masculino, pobres e negros (WAISELFISZ, 2012; PERES et al, 2006).

No caso de Guarulhos, considerando a taxa média de homicídios para a população total - apresentadas no gráfico 09 - com a taxa de mortalidade para a população entre 15 e 34 anos, essas se mostram bem superiores. Em 2000, era 269,76 caindo para 129,27 em 2010, 
mantendo-se maior que a $\operatorname{RMSP}(119,10)$ e que o $\operatorname{ESP}(117,98)$ (SEADE), vide Tabela 08, pg. 100.

Para discussão de como se distribuíam esses homicídios pelo território foi necessária a conjugação de diferentes fontes de dados, isso porque a Secretaria de Segurança Pública do Estado de São Paulo disponibiliza os dados registrados, de acordo com os Distritos Policiais, o que dificulta a identificação da distribuição desses casos na área, relativamente extensa, abrangida pelos referidos distritos.

Outro agravante é o fato de que alguns Distritos Policiais ficam fechados em finais de semana e feriados, assim, ocorrências referentes à outra área de abrangência acabam se transferindo para os Distritos de plantão. Procurou-se, então, a Secretaria de Segurança, em busca de dados mais pormenorizados do território, que apontou o Infocrim, que é formado por bancos de dados, o que permite identificar os pontos de maior incidência criminal separados por cidades, bairros e ruas. No entanto, apesar de a Secretaria ter se comprometido a disponibilizar esses dados ${ }^{10}$, não o fez de acordo com a solicitação, que se referia ao ano de 2000 e 2010 sobre os homicídios dolosos, pois seriam dados importantes e favoreceriam a comparação entre eles, em relação à cidade de Guarulhos.

Em vista disso, procuraram-se alternativas que contemplassem a qualidade dos dados e se aproximassem da espacialidade desejada, necessidades atendidas apenas parcialmente.

Para ano de 2000, os dados foram extraídos do relatório produzido pela Prefeitura, em conjunto com o Instituto Pólis, intitulado "Mapa da exclusão/inclusão social da cidade de Guarulhos", em que os homicídios foram distribuídos entre os bairros e cuja fonte foi o Sistema de

\footnotetext{
10 Após a apresentação desta Dissertação em 26/10/2012, a Secretaria de Segurança Pública de São Paulo, entrou em contato para disponibilização dos dados sobre os homicídios, que ainda não se referiam ao recorte espacial que era de interesse da pesquisa, entretanto, eram mais detalhados do que os disponíveis sobre os Distritos Policiais no site dessa secretaria. Não foi possível incluí-los porque já havia apresentado a dissertação e não tinha como compartilhar os dados com a banca examinadora.
} 
Informação de Mortalidade (SIM), vinculado ao DATASUS do Ministério da Saúde, que contempla os homicídios por agressões.

Em busca de dados mais recentes, que versassem sobre como ocorreu o declínio dos homicídios no espaço interno da cidade, obteve-se um texto fornecido pela Secretaria Municipal de Segurança, em que os dados criminais se referem aos homicídios dolosos, obtidos junto à Delegacia Seccional de Polícia de Guarulhos, e são relativos aos Boletins de Ocorrência registrados nas delegacias do Município, cujos endereços são do local do crime. Segundo o texto, a conferência dos dados, a geração dos índices e a confecção dos mapas foram de responsabilidade da Divisão de Informações da Secretaria Municipal para Assuntos de Segurança Pública.

Pela Organização Mundial de Saúde, é considerada violência epidêmica a taxa acima de 10 homicídios por grupo de 100 mil habitantes. Assim, a Figura 32 revela que, em 2000, reduzidíssimo número de bairros apresentava números inferiores a dez e sobressaem as taxas elevadas, generalizadas pelos bairros do município. Esses fatores completam a argumentação de que, no geral, a qualidade de vida dos munícipes de Guarulhos é precária.

Ao excluir os bairros com taxas inferiores a dez, e considerando as demais classes, observa-se que, em 2000, de um modo geral, à medida que se afastava do Centro onde a taxa fica entre 10 e 30, os bairros iam apresentando índices mais elevados. No sudoeste, os bairros de Itapegica e Tranquilidade superavam a taxa de 70, que corresponde à mesma dos bairros próximos ao Aeroporto e alguns da parte leste e nordeste da cidade. Nesta há outros bairros, com índices um pouco menores - entre 50 e 70 - mas, ainda assim expressivos, que incluem também os bairros situados ao norte.

Ao retomar a questão da segregação, observa-se que mesmo nos bairros melhores estruturados, havia entre eles taxas acima de 30, como Gopouva, a Vila Galvão e o Maia. Neste a taxa foi superior a 50 e para melhor compreensão desse fenômeno, seria necessário um estudo mais 


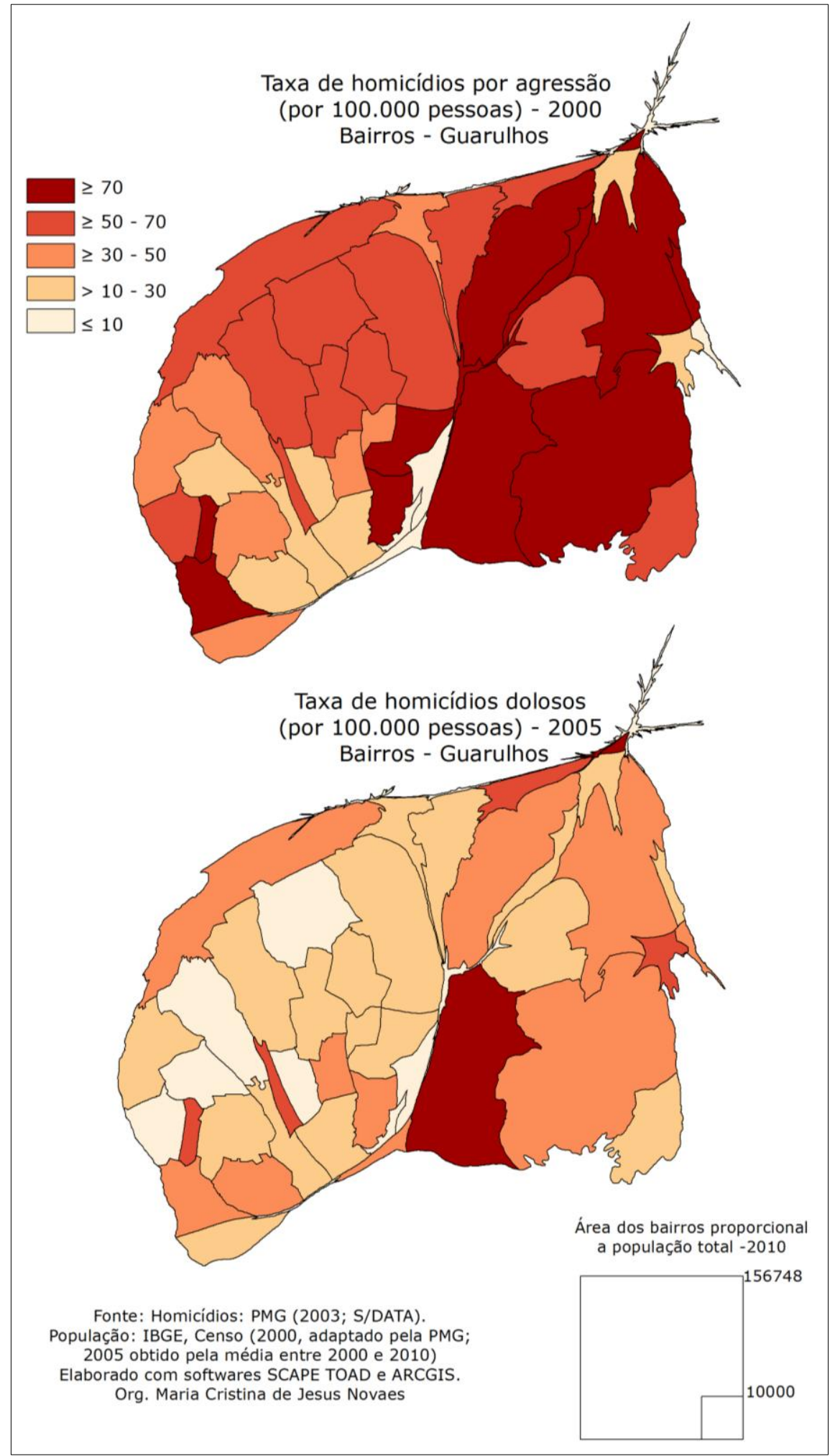

Figura 32 - Taxa de homicídios por agressão (2000) e dolosos (2005) por 100.000 pessoas - Guarulhos. 
aprofundado, haja vista que o Maia se localiza no principal eixo de consumo da Cidade, bastante visado para roubos e furtos.

Os bairros em que as taxas são superiores a 50, correspondiam àqueles que, nos mapas sobre equipamentos sociais e outros indicadores, normalmente, apresentavam os índices com as maiores desvantagens. Isso reafirma que a segregação espacial promovida pelo poder público, que privilegia subespaços do território do ponto de vista da incorporação de objetos públicos e infraestruturais importantes, contribui para o agravamento das relações sociais conflituosas.

O mapa de 2005, ao ser comparado com o de 2000, exige observação cuidadosa, visto que ele se refere apenas aos homicídios dolosos, mas é importante para a análise desse ponto de vista e de dados mais recentes. Considerando a taxa menor que 10 a cada 100.000 habitantes, os homicídios dolosos encontram-se em alguns bairros, concentrados principalmente na parte oeste da cidade. A taxa entre 10 a 30 é a que concentra o maior número de bairros do Município e adotando os valores entre 30 e 50, destacam-se os bairros populosos do leste: Pimentas, Bonsucesso, São João, o Cabuçu a noroeste, no sudoeste Itapegica e, próximos ao centro, Bom Clima e Fátima.

Com taxas que superam o valor de 70, sobressai o bairro de Cumbica, onde coexistem objetos modernos como indústrias e as numerosas moradias precárias, e que, além disso, tem que conviver com outros tipos de violência. Assim, o bairro é um dos que ilustram as contradições operantes na cidade.

Há os dados dos homicídios dolosos por Distrito Policial, referentes a 2011, os quais, como discutido, apresentam várias limitações para as análises propostas. Segundo esses dados, o 70 DP, localizado no São João, liderou o número de ocorrências, que foram ao todo 69, seguido pelo $4^{\circ}$ DP situado em Bonsucesso, com 35 ocorrências, vindo, em seguida, o $8^{\circ} \mathrm{DP}$, posicionado no Jardim Cumbica, com 26 ocorrências e, em quarto, o 90 DP localizado no Taboão, com 20. 
Relativizando esses dados, visto que não mostram a distribuição pelos bairros, mas indicam que os distritos mais periféricos lideram com o maior número de homicídios, em relação aos centrais, em que o $1^{\circ} \mathrm{DP}$ (Centro) e o $2^{\circ}$ DP (Vila Galvão) funcionam em esquema de plantão, além do $4^{\circ}$ DP. O DP que registrou o menor número fica posicionado na Vila Augusta, com quatro ocorrências, constituindo um dos bairros com os melhores indicadores do Município, englobado na área segregada.

Embora as taxas de homicídios venham se reduzindo nas regiões metropolitanas, o Brasil praticamente manteve a mesma média, porque esse tipo de crime se espraiou pelo interior do território, em cidades que, outrora, apresentavam baixos índices de criminalidade. Segundo Waiselfisz (2012) contribuíram para essa mudança de perfil a desconcentração econômica do país, o aumento do investimento em segurança nas grandes cidades e a melhoria nos sistemas de captação de dados sobre crimes nos pequenos municípios.

A redução dos homicídios no Estado de São Paulo, segundo a Secretaria de Segurança, resulta, principalmente, do aumento do investimento do Governo em segurança pública, a partir da retirada de armas ilegais das ruas, nos últimos 12 anos, da intensificação do policiamento preventivo e da investigação especializada de homicídios, pelo DHPP (Departamento de Homicídios e Proteção à Pessoa) e Setores de Homicídios das delegacias seccionais de polícia.

Em 2011, o Estado de São Paulo apresentou taxa de 9,8 a cada 100.000 e, reafirmando o caráter desigual na distribuição dos homicídios, Guarulhos apresentou taxa média de 16,3.

A explicação para a redução do número de homicídios, por ações do Governo Estadual, concentra-se nos investimentos em segurança, o que quer dizer que parte da população que cometeu os homicídios se encontra encarcerada. Assim, o que remedeia para a maioria, na verdade constitui uma solução apenas parcial, posto que os problemas estruturais continuam operantes, o que leva à pergunta: - Quem são as pessoas que 
lotam os presídios? A quais condições territoriais essas pessoas foram submetidas?

Essas ações do Governo Estadual em segurança resultaram no avanço dos aportes financeiros para a acelerada expansão do sistema penitenciário paulista, ultrapassando os investimentos anuais das ricas universidades estaduais Unicamp e Unesp (ZOMIGHANI JUNIOR, 2009). Por outro lado no município de Guarulhos, como destacado, vem diminuindo seu investimento junto às escolas estaduais, o que poderia ser uma alternativa ao enfrentamento da violência estrutural.

É importante destacar que uma forma de redução do número de homicídios, seria a diminuição da violência policial, visto que $22,3 \%$ das ocorrências de 2011 foram atribuídas a ela, as quais, nas estatísticas aparecem, normalmente, como resistência seguida de morte, que foram 229 delas e 61 foram homicídios dolosos praticados fora do trabalho (Um em cada cinco..., 27 de janeiro 2012). Isso levanta para a análise do território, onde são praticados tais confrontos, para saber qual o perfil social das vítimas, o que revelaria, provavelmente, a desigualdade entre essa população e no interior da cidade.

$\mathrm{Na}$ verdade, a questão da segurança como principal indicador para a diminuição dos homicídios considera-se que deve ser relativizada para Guarulhos. Primeiro, porque Guarulhos usufrui de condição privilegiada, por estar inserida na RMSP, possibilitando sua posição de destaque no setor produtivo brasileiro. Isso fez com que as condições territoriais, no geral, sofressem a adequação em virtude da expansão do setor produtivo, ao mesmo tempo em que, nos últimos anos, houve diminuição do desemprego e expansão do consumo, fatores que sugerem a sua correlação com a diminuição dos homicídios.

Entretanto, é importante o acompanhamento desse processo, para melhor compreendê-lo, sobretudo, porque a questão dos homicídios sofre diretamente a interferência das questões conjunturais, atreladas ao processo de globalização que, em crise, impõe medidas de austeridades que ampliam as carências dos serviços públicos. 


\section{CONSIDERAÇÕES FINAIS}

No período histórico atual, as cidades estão se tornando cada vez mais complexas, em função do ritmo acelerado das transformações urbanas e da multiplicidade de técnicas e objetos incorporados, entre outros motivos. Nesse contexto, considera-se que o mapa, pela particularidade de sua linguagem, promove uma visualização dos fenômenos e das informações que contribuem bastante para o entendimento das lógicas espaciais das cidades. Além disso, o mapa é aqui tratado como um instrumento de democratização das informações para a sociedade em geral.

A força da linguagem cartográfica pode ser expressa na comparação com a linguagem escrita. Esta não consegue ser tão sintética e suscetível à apreensão instantânea das desigualdades espaciais como os mapas. Entretanto, é preciso reconhecer dificuldades da linguagem cartográfica a serem superadas, para que os mapas se constituam, realmente, um polo consistente do discurso geográfico e das ciências sociais em geral.

A associação de mapas com fundo euclidiano e as anamorfoses feita no trabalho mostrou-se bastante produtiva, visto que, em cada um dos tipos, foi possível explorar potencialidades específicas, o que permitiu a visualização de ângulos distintos das espacialidades existentes.

As anamorfoses foram concebidas com o fundo de mapa construído a partir da população absoluta dos bairros. Elas se mostraram produtivas por dar visualização, já expressas no fundo do mapa, à distribuição populacional nos espaços internos do Município. As anamorfoses dos anos de 1980, 1991, 2000 e 2010 mostraram a evolução do adensamento populacional dos bairros, o que deu sentido ao conceito de cidade espraiada.

As anamorfoses se valorizaram enquanto instrumento de percepção por dois motivos: 1. As densidades populacionais extremas encontradas e, 2. A velocidade do crescimento populacional do Município. Vale ressaltar a 
forma de utilização do território guarulhense em que, praticamente $1 / 3$ de área contínua é constituída por áreas naturais, e a população, por sua vez, concentra-se nos outros 2/3.

Outro destaque das anamorfoses de fundo populacional aconteceu ao implantar informações temáticas sobre esse fundo, ocasião em que se verificou o potencial da visualização das correlações, o que foi muito importante para as análises construídas nesta pesquisa. Conforme Milton Santos, "é somente a relação que existe entre as coisas que nos permite realmente conhecê-las e defini-las. Fatos isolados são abstrações e o que Ihes dá concretude é a relação que mantêm entre si" (2008, p.25). As correlações foram importantes, em especial, para aquelas situações em que apenas a informação da localização dos objetos era insuficiente, já que seria necessário considerar o seu uso pela população.

Para ilustrar, num mapa com o fundo euclidiano a densidade dos objetos visualizada está de acordo com a dimensão territorial do bairro, que aparentemente pode ser elevada, mas que se desfaz diante do número de pessoas que necessita utilizar esses objetos. Nesse quesito, o fundo populacional da anamorfose propiciou a comparação e a correlação da densidade dos objetos e dos usos, e "desmascarou" pretensas suficiências de equipamentos em alguns bairros, como foi o caso da quantidade de creches nos bairros como os Pimentas, as quais, apesar de numerosas, se mostraram insuficientes diante da concentração de crianças que necessitam desse atendimento.

As anamorfoses exigem o exercício de outros referenciais para a leitura espacial, o que, a princípio pode ser uma dificuldade, mas, ao mesmo tempo, representam possibilidades de rompimento com a naturalização dada pelos mapas com fundo euclidiano, embora esses também tenham sido importantes no presente trabalho.

Optou-se pelos mapas com fundo euclidiano para representar alguns dados absolutos, por meio de representações quantitativas, importantes para diferentes análises. Esses mapas também foram utilizados para os dados em que a localização era a informação mais 
relevante, como no caso dos equipamentos públicos e de infraestrutura. Essas localizações ajudam a embasar a análise sobre a segregação.

Recorreu-se, também, à modelização gráfica para a representação das áreas que possuem melhores condições infraestruturais públicas, pois esse recurso possibilita a simplificação visual do recorte espacial. Nesse recorte as áreas segregadas não ocupam a totalidade da superfície territorial dos bairros, incluindo, ainda, o sistema principal de circulação.

Com relação ao encaminhamento da pesquisa, baseada nas teorias e método de Milton Santos, destaca-se a importância da discussão dos meios geográficos de Guarulhos para o entendimento das desigualdades territoriais, isso contando também com a contribuição da linguagem cartográfica.

A segregação consistiu na identificação das áreas que tinham melhor acesso aos equipamentos e serviços públicos, principalmente. O que daria a essa tarefa de identificar a segregação uma contribuição maior, seria a possibilidade de cartografar a diversidade interna dos bairros. No entanto, no caso de Guarulhos, são poucos dados disponíveis que permitiriam esse trabalho.

Guarulhos tem como condição uma posição estratégica na RMSP, pois é recortada pelo sistema de circulação nevrálgico para a movimentação do meio técnico-científico-informacional, além da proximidade com a capital paulista. Ao mesmo tempo em que essa condição agrega valor ao seu território, ela é também sua sangria, como aponta Maria Adélia de Souza (2002). Sangria que se manifesta, por exemplo, na questão ambiental e na situação social da área urbanizada e na prevalência dos projetos urbanos investido pelo poder público.

Quanto à questão da violência, que foi o cerne da discussão da dissertação, ela permeia a vida das pessoas de diferentes formas. No momento em que os índices de homicídios cresciam ininterruptamente, sobretudo nas áreas periféricas (povoadas com intensidade desde meados dos anos 1970), podia-se relacioná-los às piores situações infraestruturais dessas áreas, expondo a violência estrutural a que foram submetidos 
aqueles que vieram em busca de melhores condições de vida, o que, num determinado período constituiu parte significativa da população.

Essa condição ainda está presente nos dias atuais, e se comprova com a precariedade do acesso aos equipamentos e serviços públicos. Isso contribui para explicar os indicadores de desvantagens do Município de Guarulhos na RMSP e no ESP. Vale resgatar que, mesmo tendo diminuído os índices de homicídios, persiste a desigualdade na distribuição deles pelo município, apesar da dificuldade em obter dados mais detalhado para aprofundar essa constatação.

Em relação aos indicadores econômicos de produção, Guarulhos ocupa boa posição no Brasil. Mas, o mesmo não ocorre com as médias de rendimento salarial dos setores produtivos e por domicílio, que são inferiores ao conjunto da RMSP e ESP, em sua maioria.

É importante destacar o processo de verticalização que se concentra nas áreas melhores equipadas e contribui com as desigualdades territoriais, uma vez que os subespaços são valorizados ou sobrevalorizados a partir da renovação urbana promovida por tal processo.

Atualmente, parte da população conta com acesso precário aos equipamentos públicos. Outra parte sequer tem qualquer acesso a eles. $\mathrm{O}$ que se espera é que se avance na discussão da qualificação desses equipamentos, visando à melhoria da qualidade de vida nas áreas marcadas pela escassez, pois o acesso a tais equipamentos públicos é condição sine qua non, para o bem-estar da população.

As ações que movimentam e que dão vida a esses objetos são as que vão assegurar o acesso com qualidade e, para tal, é necessário advogar o território como totalidade, não de modo seletivo, como se pode observar. A seletividade potencializa a segregação socioespacial. 


\section{BIBLIOGRAFIA}

ADORNO, Sergio. Crime e violência na sociedade brasileira contemporânea. Jornal de Psicologia-PSI, n. Abril/Junh, p. 7-8, 2002. Disponível em: http://www.nevusp.org/downloads/down103.pdf. Acesso em 09/04/2012.

ADORNO, Sergio. Exclusão sócio-econômica e violência urbana. In: Sociologias. Porto Alegre, ano 4, no 8, jul/dez 2002, p. 84-135. Disponível em: http://www.nev.prp.usp.br/ Acesso em 12/04/2011.

AGUILAR, Annabel Pérez et al. Ciclo do ouro, Guarulhos (SP). In Carlos SCHOBBENHAUS, Carlos \& SILVA, Cássio Roberto da (orgs). Geoparques do Brasil: propostas. Rio de Janeiro: CPRM, p.543-582. 2012.

ALBUQUERQUE, Mariana Vercesi de. Território usado e saúde: respostas do sistema único de saúde à situação geográfica de metropolização em Campinas - SP. 2006. 130 p. Dissertação de Mestrado - Departamento de Geografia - Faculdade de Filosofia Letras e Ciências Humanas, Universidade de São Paulo da USP, São Paulo, 2006.

ARAÚJO, Maria de Fátima I. Reestruturação produtiva e transformações econômicas: região metropolitana de São Paulo. São Paulo em Perspectiva, v15, n.1, 2001, p.20-30. Disponível em: http://www.scielo.br/pdf/spp/v15n1/8586.pdf. Acesso em 09/06/2012.

ARCHELA, Rosely Sampaio e THÉRY, Hervé. Orientação metodológica para construção e leitura de mapas temáticos. In: Confins [Online], 3. 2008. http://confins.revues.org/3483. Acesso em 30/04/2012.

BALBIM, Renato Nunes. Fragmentação da metrópole e seletividade socioespacial. In Revista Experimental, Ano I - n.1, p21-32, julho, 1996.

BARROS, Ana Maria Leite de; et al. Violência e espaço urbano: o caso dos homicídios da aglomeração urbana de Vitória". In: VI Congresso Brasileiro de Geógrafos Goiânia -Goiás- jul. 2004. Disponível em: http://www.igeo.uerj.br/vicbg-2004/eixo1/e1 211.htm. Acesso em 10/09/2009.

BORD, Jean-Paul. Géographie et sémiologie graphique : deux regards differéntes sur l'espace. In : Colloque $\mathbf{3 0}$ ans de semiologie graphique, novembro de 1997. Disponível em: http:// www.cybergeo.eu/index258.html. Acesso em 21/04/2012.

BRASIL. Ministério do Planejamento, Orçamento e Gestão. Instituto Brasileiro de Geografia e Estatística. Contagem Populacional. 
Disponível em: http://www.sidra.ibge.gov.br/bda/popul/ Acesso em $12 / 04 / 2011$.

BRUNET, Roger. "Appendre à lire dans les cartes". PRÉfACES, Paris, 1988, 5:98-103 p.

CALDEIRA, Tereza Pires do Rio. Cidade de Muros: Crime, Segregação e Cidadania em São Paulo. São Paulo: EDUSP, 2000. 400 p.

CANO, Wilson. Desequilíbrios regionais e concentração industrial no Brasil. Campinas: Unicamp, 1998. 369 p.

CÁRDIA, Nanci. "Jovens, violência fatal, superposição de carências e mercado de trabalho". Rio universal. São Paulo - Rio de Janeiro: Editora Record, 2000. Disponível em: http://www.nev.prp.usp.br/ Acesso em $12 / 04 / 2011$.

CÁRDIA, Nanci; SCHIFFER, Sueli. Violência e desigualdade social. São Paulo. 2002. Disponível em: http://www.nev.prp.usp.br/ Acesso em $12 / 04 / 2011$.

CAUVIN, Collete. Transformações cartográficas espaciais e anamorfoses. In: DIAS, M. H. (Coord.) Os mapas em Portugal: da tradição aos novos rumos da cartografia. Lisboa: Cosmos, 1995. p. 267-310.

CHAUI, Marilena. Uma ideologia perversa. Explicações para a violência impedem que a violência real se torne compreensível. In: Folha on line, São Paulo, 14 mar. 1999. Disponível em: http://www1.folha.uol.com.br/fol/brasil500/dc 1 4.htm Acesso em 12/04/2011.

FERREIRA, Ignez Costa Barbosa e PENNA, Nelba Azevedo. Território da violência: um olhar geográfico sobre a violência urbana. In: GEOUSP Espaço e Tempo, São Paulo, No 18, 2005, p. 155 - 168. Disponível em www.geografia.fflch.usp.br/publicacoes/Geousp/index.htm. Acesso em 23/04/12.

FONSECA, Fernanda Padovesi; OLIVA, Jaime Tadeu. A Geografia e suas linguagens: O caso da Cartografia. In CARLOS, Ana Fani Alessandri (org.). A Geografia na sala de aula. São Paulo: Contexto, 2002. p. 62-78.

FONSECA, Fernanda Padovesi. A inflexibilidade do espaço cartográfico, uma questão para a Geografia: análise das discussões sobre o papel da Cartografia. 2004. 251f. Tese (Doutorado em Geografia Física) - Departamento de Geografia - Faculdade de Filosofia Letras e Ciências Humanas, Universidade de São Paulo da USP, São Paulo, 2004. 
FONSECA, Fernanda Padovesi. O potencial analógico da cartografia. Boletim Paulista de Geografia, São Paulo, nº 87, p. 85-110, 2007.

FONSECA, Fernanda Padovesi. A naturalização como obstáculo à inovação da cartografia escolar. In: Geografares, Vitória, no 12, jul., p. 175-210, 2012. Disponível em: http://www2.cchn.ufes.br/geoufes/geografares/?N\%FAmeros publicados: Nr. 01. Acesso em 06/07/2012.

GAMA, Nilton Cesar de Oliveira. O processo de conformação da periferia urbana no município de Guarulhos: os loteamentos periféricos como (re)produção de novas espacialidades e lugar de reprodução da força de trabalho. 2009. 209 f. Dissertação de Mestrado - Departamento de Geografia - Faculdade de Filosofia Letras e Ciências Humanas, Universidade de São Paulo da USP, São Paulo, 2009.

GIRARDI, Gisele. Leitura de mitos em mapas: um caminho para repensar as relações entre geografia e cartografia. In: Geografares, Vitória, v. 1, no 1 , jun., p. 41-50, 2000. Disponível em: http://www2.cchn.ufes.br/geoufes/geografares/?N\%FAmeros publicados: Nr. 01. Acesso em 21/04/2012.

GIRARDI, Gisele. Cartografia geográfica: reflexões e contribuições. Boletim Paulista de Geografia, São Paulo, nº 87, p. 45-67, 2007.

HARLEY, John Brian. A nova história da cartografia. O Correio da UNESCO (Mapas e cartógrafos), Brasil, ano 19, n. 8, ago. p. 4-9, 1991.

HARLEY, John Brian. Mapas, saber e poder. In: Confins [Online]. Posto online em 24 Abril 2009. Disponível em: http://confins.revues.org/5724. Acesso em 11/04/2011.

HUGHES, Pedro Javier Aguerre. Segregação socioespacial e violência na cidade de São Paulo - referências para a formulação de políticas públicas. In: São Paulo em perspectiva (on line), vol.18, n.4: p. 93-102, 2004. Disponível em: http://www.scielo.br/scielo.php?pid=S0102-

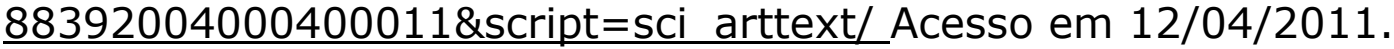

KOWARICK, Lúcio. A espoliação urbana. Rio de Janeiro: Paz e Terra, 1979. 208p.

KOWARICK, Lúcio. O preço do progresso: crescimento econômico, pauperização e espoliação urbana, in: Moises, J. A. (Org.). Cidade, Povo e Poder. Rio de Janeiro: CEDEC / Paz e Terra, pp. 30-48, 1982.

LÉVY, Jacques. La carte, um espace à construire. In: LÉVY, Jacques; PONCET, Patrick; TRICOIRE, Emmanuelle. La carte, enjeu contemporain. Paris, Dossier no 8036, Documentation photographique, 
La Documentation Française, 2003. p. 1-16. Disponível em: http://sciences-po.macrocosme.net/lectures/LevyCarteEnjeu.pdf. Acesso em 13/04/2011.

LÉVY, Jacques e LUSSAULT, Michel (org.). Espace. In: Dictionnaire de la Géographie et de I'espace des sociétés. Paris: Belin, 2003. p. 325333. Tradução de trabalho de Monica Balestrin Nunes, jul./2009 com comentários de Jaime Tadeu Oliva.

LÉVY, Jacques. Uma virada cartográfica? In: ACSELRAD, Henri (org.). Cartografias sociais e território. Rio de Janeiro: UFRJ/IPPUR, 2008. p. 153-167.

MELGAÇO, Lucas. Securização urbana: da psicoesfera do medo à tecnoesfera da segurança. 2010. 274f. Tese (Doutorado em Geografia Humana) - Departamento de Geografia -Faculdade de Filosofia Letras e Ciências Humanas, Universidade de São Paulo, São Paulo, 2010.

MONTENEGRO, Marina Regitz. O circuito inferior da economia urbana na cidade de São Paulo no período da globalização. 2006. 203f. Dissertação (Mestrado em Geografia Humana) - Departamento de Geografia -Faculdade de Filosofia Letras e Ciências Humanas, Universidade de São Paulo, São Paulo, 2006.

NEGRI, Silvio Moisés. Segregação Socioespacial: Alguns Conceitos e Análises. Coletâneas do nosso tempo, Rondonópolis - MT, v. VII, no 8 , p. 129 a $153, \quad 2008.2$ Disponível em http://200.129.241.94/index.php/coletaneas/article/viewFile/64/25. Acesso em 11/04/2011.

NORONHA, Adolfo Vasconcelos. IV Centenário Guarulhos. São Paulo: Prefeitura de Guarulhos, 1960. p.206.

OLIVA, Jaime Tadeu. A Cidade sob Quatro Rodas. O automóvel particular como elemento constitutivo e constituidor da cidade de São Paulo: o espaço geográfico como componente social. 2004. 355f. (Doutorado em Geografia Humana) - Departamento de Geografia Faculdade de Filosofia Letras e Ciências Humanas, Universidade de São Paulo da USP, São Paulo, 2004.

OLIVEIRA, Antonio M. Santos.; ANDRADE, Marcio. R. Magalhães.; SATO, Emi; QUEIROZ, William. Bases Geoambientais para um Sistema de Informações Ambientais do Município de Guarulhos. Guarulhos: Laboratório de Geoprocessamento. Universidade Guarulhos (Relatório FAPESP), 196 p., 2v., Mapas. 2009. 
OLIVEIRA, Elton Soares de et al. Guarulhos: espaço de muitos povos. São Paulo: Noovha América. Série conto, canto e encanto com a minha história. 2007. p. 128.

OMAR, Elmi El Hage et al. Guarulhos tem história: questões sobre história natural, social e cultural. São Paulo: Ananda Gráfica e Editora, 2008. 200 p.

PAIM, Jairnilson et al. Saúde no Brasil 1 - 0 sistema de saúde brasileiro: história, avanços e desafios. 2011 p.11-21. Disponível em:

http://download.thelancet.com/flatcontentassets/pdfs/brazil/brazilpor1.pd f. Acesso em 28/06/2012.

PERES, Maria Fernanda Tourinho; CARDIA, Nancy; SANTOS, Patrícia Carla dos. Homicídios de crianças e jovens no Brasil: 1980-2002. Núcleo de Estudos da Violência, Universidade de São Paulo. São Paulo:NEV/USP, [2006]. 311 p.

PILOTTO, Angela; et al. Análise da Situação Atual: Revisão do Plano Diretor de Desenvolvimento Urbano, Econômico e Social de Guarulhos - SP. Curitiba: Ambiens, 2012.

PINHEIRO, José Elmano de Medeiros. O ciclo do ouro em Guarulhos. In OMAR, Elmi El Hage (org). Guarulhos tem história: questões sobre história natural, social e cultural. São Paulo: Ananda Gráfica e Editora, p. 74-87. 2008.

Por "fim digno, aposentado se mata em praça pública na Grécia. Folha de São Paulo. São Paulo, 05 abril 2012. Cad. 1 , p.12

Um em cada cinco mortos em São Paulo é vítima de PM. Folha de São Paulo. São Paulo, 27 de janeiro de 2012. Cotidiano.

PMG - PREFEITURA MUNICIPAL DE GUARULHOS. A melhor opção para investir em Guarulhos. Guarulhos, Sem data.

PMG - PREFEITURA MUNICIPAL DE GUARULHOS. A Criminalidade e o Jovem em Guarulhos. Secretaria Municipal para Assuntos de Segurança Pública. Guarulhos, Sem data.

PMG - PREFEITURA MUNICIPAL DE GUARULHOS. Diagnóstico Preliminar para o Plano Diretor de Guarulhos. Guarulhos: Instituto Polis. 2002. Disponível em CD ROM.

PMG - PREFEITURA MUNICIPAL DE GUARULHOS. Mapa da exclusão/inclusão social da cidade de Guarulhos. Guarulhos, 2003. 
PMG - PREFEITURA MUNICIPAL DE GUARULHOS. Plano Diretor de Drenagem: Diretrizes, orientações e propostas, 2007.

PMG - PREFEITURA MUNICIPAL DE GUARULHOS. Plano Municipal de Saúde de Guarulhos 2010-2013. Prefeitura Municipal de Guarulhos/Integra. Guarulhos 2010. Disponível em: http://www.guarulhos.sp.gov.br/files/plano m saude 20102013 final j ulho-11.pdf. Acesso em 30/06/2012.

PMG - SECRETARIA DE HABITAÇÃO. Plano local de habitação de interesse social de Guarulhos. Prefeitura Municipal de Guarulhos/Integra. Guarulhos 2011. Disponível em: http://www.guarulhos.sp.gov.br/arquivos/arquivos2/PLHIS Guarulhos Fin al.pdf. Acesso em 20/06/2012.

PONCET, Patrick. Le Monde, impératif cartographique. Comment cartographier la mondialisation? Disponível em : http://www.cafegeo.net/article.php3?id article=1070. Acesso em 12/04/2011.

Quem é Quem na Economia de Guarulhos, Guarulhos, Set, 2008. As dez maiores do Quem é Quem 2008. Olho Vivo. Publicação 30/09/2008.

RIVERO, Patricia. S. Segregação urbana e distribuição da violência. In: DILEMAS: REVISTA DE ESTUDOS DE CONFLITO E CONTROLE SOCIAL - Vol. 3 - no 9 - jul/ago/set 2010 - p. 117-142.

http://revistadil.dominiotemporario.com/doc/Dilemas9Art5.pdf. Acesso em: 12/04/2011.

RODRIGUES, Arlete Moyses. Geografia e violência urbana in PONTUSCHKA, N. N. \& OLIVEIRA, A. U. de (orgs.) Geografia em perspectiva. São Paulo: Contexto, p.77-86. 2004.

ROMÃO, José Gasparino, NORONHA, Adolfo de Vasconcelos. Guarulhos 1880-1980. Guarulhos: PMG/Academia Guarulhense de Letras, 1980.

SANTOS, Carlos José Ferreira dos. Identidade Urbana e Globalização: a formação dos múltiplos territórios em Guarulhos SP. São Paulo: ABBABLUME, GUARULHOS Sinpro, 2006. 247p.

SANTOS, Milton Metamorfoses do Espaço Habitado. São Paulo. Edusp, 1988.

SANTOS, Milton. O espaço do cidadão. São Paulo: Nobel, 1993.142p.

SANTOS, Milton. A urbanização Brasileira. São Paulo: Hucitec, 1994a. $157 p$. 
SANTOS, Milton. Técnica, espaço, tempo: globalização e meio técnico-científico-internacional. São Paulo : Hucitec, 1994b. 190p.

SANTOS, Milton. A Natureza do espaço: técnica e tempo, razão e emoção. São Paulo. HUCITEC. 1997. [1996]. 308p.

SANTOS, Milton. O retorno do território. In: M. Santos; M. A A Souza; M. L. Silveira (org). Território, Globalização e Fragmentação. São Paulo: Hucitec,1998. p.15-20.

SANTOS, Milton. Por uma outra globalização: do pensamento único à consciência universal. São Paulo - Rio de Janeiro: Editora Record, 174p. 2000.

SANTOS, Milton et al. O papel ativo da Geografia: um manifesto. In: ENCONTRO NACIONAL DE GEÓGRAFOS. Florianópolis - SC, jun. 2000.

SANTOS, Milton. Economia Espacial: Críticas e Alternativas. São Paulo: Edusp. 2003 [1979]. 204p.

SANTOS, Milton. Por uma Geografia Nova. Da crítica da Geografia a uma Geografia Crítica. São Paulo: Edusp. 2004 [1978]. 285p.

SANTOS, Milton. Da totalidade ao lugar. São Paulo: EDUSP, 2005.170p.

SANTOS, Milton. Espaço e Método. São Paulo: Edusp, 2008 [1985]. $118 \mathrm{p}$.

SANTOS, Milton. Metrópole Corporativa Fragmentada: o Caso de São Paulo. São Paulo: Edusp, 2009a [1990]. 136 p.

SANTOS, Milton. Por uma Economia Política da Cidade: o Caso de São Paulo. São Paulo: Edusp, 2009b [1994]. 144 p.

SANTOS, Milton e SILVEIRA, Maria Laura. O Brasil-Território e sociedade no início do século XXI. Rio de Janeiro- São Paulo: Record, 2001. 473p.

SILVEIRA, Maria Laura (2006a). O espaço geográfico: da perspectiva geométrica à perspectiva existencial. In GEOUSP - Espaço e Tempo, São Paulo, no 19, p. 81 - 91, 2006.

SILVEIRA, Maria Laura (2006b). Porque há tantas desigualdades sociais no Brasil. In: Edu Silvestre de. Que país é esse?: Pensando o Brasil contemporâneo. São Paulo, SP, Editora Globo, c2006. 372 p. 
SILVEIRA, Maria Laura (2008). Entrevista com a Professora Maria Laura Silveira. IN Revista Discente Expressões Geográficas. Florianópolis. No04, p. 01-15, maio/2008 Disponível em: www.geograficas.cfh.ufsc.br Acesso em 15/5/2012.

SINGER, Paul. Desenvolvimento econômico e evolução urbana. São Paulo: Nacional, 1977. p.377.

SINGER, P. Economia política da urbanização. São Paulo: Brasiliense, 1973. p. 155.

SINGER, Paul. A crise do milagre: interpretação crítica da economia brasileira. Rio de Janeiro: Paz e Terra, 1989. p.167.

SOUZA, Maria Adélia Aparecida de. Regionalização: tema geográfico e político - o caso paulista. In: Boletim Paulista de Geografia, Associação dos Geógrafos Brasileiros, São Paulo, n050, p. 103 -134, mar. 1976.

SOUZA, Maria Adélia Aparecida de. Identidade da metrópole: a verticalização em São Paulo. São Paulo: Hucitec, 258 p.1994.

SOUZA, Maria Adélia Aparecida de. Política e Território A Geografia das Desigualdades. 2002

Disponível em http://www.belem.pa.gov.br/planodiretor/pdfs/Politica Territorio Texto MARIA ADELIA.pdf . Acesso em 12/04/2011.

SOUZA, Maria Adélia Aparecida de. O retorno do território. Apresentação por Maria Adélia Aparecida de Souza. En publicación: OSAL, Observatorio Social de América Latina, año VI, no. 16. CLACSO, Consejo Latinoamericano de Ciencias Sociales, Buenos Aires, Argentina: Argentina. 2005. Disponível em: http://bibliotecavirtual.clacso.org.ar/ar/libros/osal/osal16/D16Santos.pdf. Acesso em 15/5/2012.

SOUZA, Maria Adélia Aparecida de. A Geografia da Solidariedade. In: Geotextos. Vol.2 n.2, p 171-178. 2006.

SPOSITO, M. E. B. Reestruturação urbana e segregação socioespacial no interior paulista. Scripta Nova. Revista electrónica de geografía y ciencias sociales. Barcelona: Universidad de Barcelona, 1 de agosto de 2007, vol. XI, núm. 245 (11). Disponível em: <http://www.ub.es/geocrit/sn/sn-24511.htm> [ISSN: 1138-9788]. Acesso em 12/04/2011.

TEIXEIRA, Alam Gualberto. A possibilidade de vitimização: qualidade de vida e a criminalidade. In Revista de Iniciação Científica da FFC, v. 4, 
n. 3, 2004. Disponível em http://www2.marilia.unesp.br/revistas/index.php/ric/article/view/139. Acesso em 12/06/2012.

VILLAÇA, Flavio. O Espaço intra-urbano no Brasil. São Paulo: Nobel/Lincoln/Fapesp, 1998. 376 p.

VILLAÇA, Flavio. A segregação urbana e a justiça (ou a justiça no injusto espaço urbano). In Revista Brasileira de Ciências Criminais, ano 11, n.44, julho/setembro. 2003, p.341/346. Disponível em http://www.flaviovillaca.arq.br/artigos01 c p1.html. Acesso em $11 / 05 / 2012$.

Violência recua em São Paulo no 20 trimestre. Folha de São Paulo, Caderno Cotidiano, São Paulo, 28 jul. 2010, p. 1

Waiselfisz, Julio Jacobo. Mapa da violência 2012: os novos padrões da violência homicida no Brasil. São Paulo. 2011. Disponível em http://www.mapadaviolencia.org.br/. Acesso em 09/07/2012

Waiselfisz, Julio Jacobo. Mapa da violência 2012: dos municípios brasileiros. São Paulo. $2008 . \quad$ Disponível em http://www.mapadaviolencia.org.br/. Acesso em 09/07/2012.

Waiselfisz, Julio Jacobo. Os Jovens do Brasil. São Paulo. 2011. Disponível em http://www.mapadaviolencia.org.br/. Acesso em 09/07/2012.

ZALUAR, Alba. Condomínio do diabo. Rio de Janeiro: Revan/Ed UFRJ, 1994. $280 \mathrm{p}$.

Zomighani Junior, James Humberto. Território ativo e esquizofrênico: prisão e pena privada de liberdade no Estado de São Paulo. Dissertação (Mestrado em Geografia Humana) - Departamento de Geografia -Faculdade de Filosofia Letras e Ciências Humanas, Universidade de São Paulo, São Paulo, 2009.

\section{SITES CONSULTADOS}

http:// www.ibge.gov.br: CENSOS DEMOGRÁFICOS.

http://cnes.datasus.gov.br/Index.asp?home=1: DATASUS.

http://www.infraero.gov.br/index.php/br/aeroportos/sao-paulo/aeroportointernacional-de-sao-paulo.html: INFRAERO.

http://www.inep.gov.br/: CENSO ESCOLAR. 
http://www.ssp.sp.gov.br/:SECRETARIA SEGURANÇA PÚBLICA - SP. http://www.seade.gov.br/: SEADE.

http://webgeo.guarulhos.sp.gov.br/webgeo/index.php: WEBGEO. http://scapetoad.org: SCAPETOAD.

http://philcarto.free.fr: PHILCARTO. 